This manuscript was awarded the Prize of the Rector of the University of Zagreb for the academic year 2016/17 and was published in Hieronymus: Journal of Translation Studies and Terminology, 4(1), 1-27, published version available at https://urn.nsk.hr/urn:nbn:hr:131:828954

Sveučilište u Zagrebu

Filozofski fakultet

Odsjek za germanistiku

Petar Gabrić, Iva Brajković, Letizia Licchetta, Juraj Bezuh, Dorotea Kelčec Ključarić ANALIZA STRATEGIJA PREVOĐENJA FILMSKIH NASLOVA NA HRVATSKI I NJEMAČKI JEZIK 
Ovaj rad izrađen je na Odsjeku za germanistiku Filozofskog fakulteta pod vodstvom redovitog profesora dr. sc. Velimira Piškorca i predan je na natječaj za dodjelu Rektorove nagrade u akademskoj godini 2016./2017. 


\section{SADRŽAJ RADA}

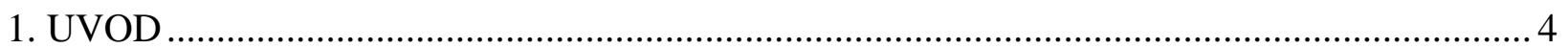

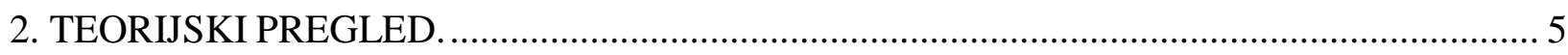

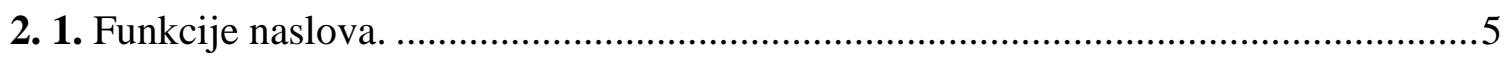

2. 2. Komercijalna funkcija naslova. .........................................................................

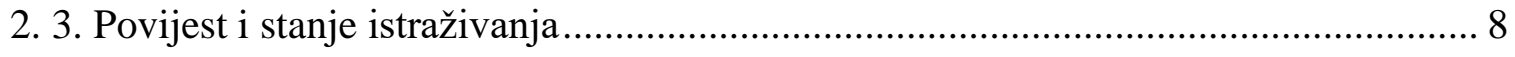

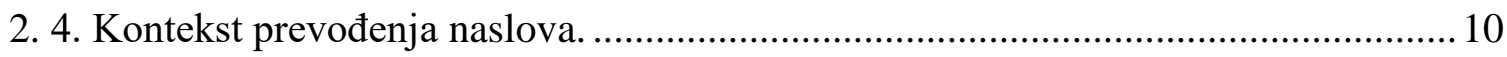

2. 5. Pitanje definicije prijevoda ................................................................................ 14

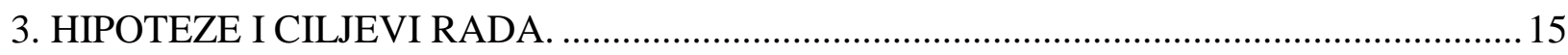

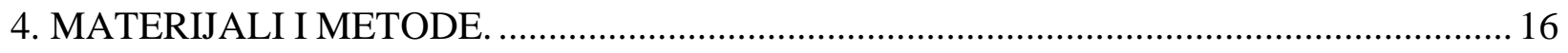

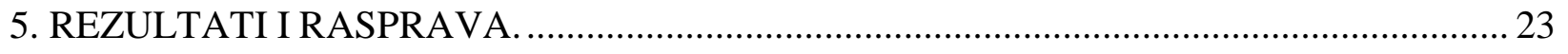

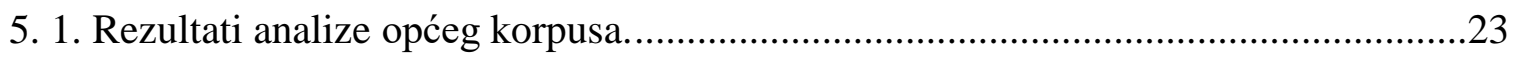

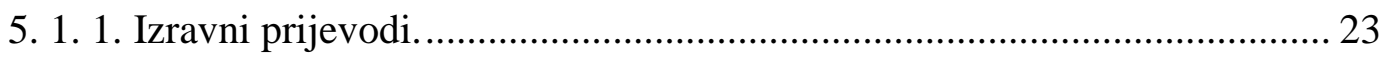

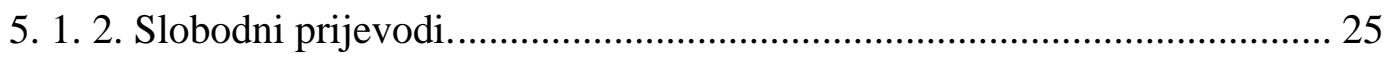

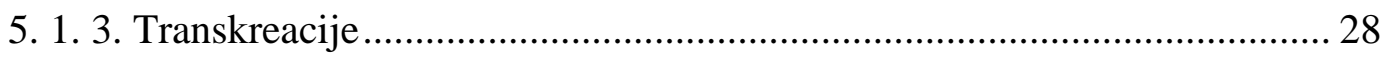

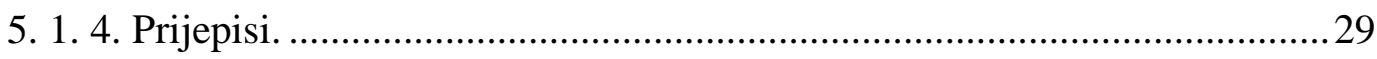

5. 1. 5. Kombinacije prijevoda i prijepisa.......................................................... 32

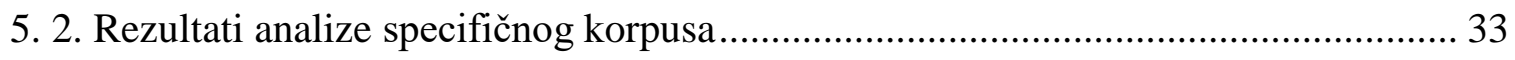

5. 2. 1. Naslovi romantičnih komedija .............................................................. 34

5. 2. 2. Naslovi horora................................................................................. 34 


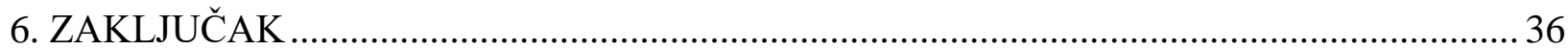

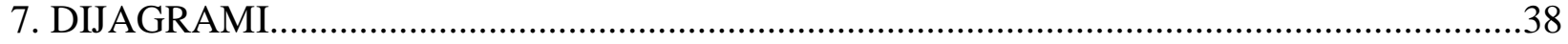

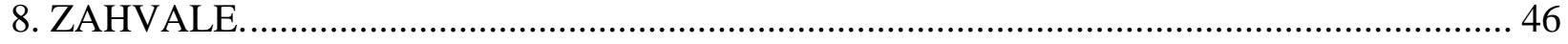

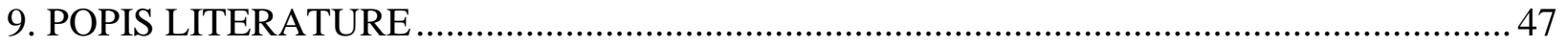

10. SAŽETAK.

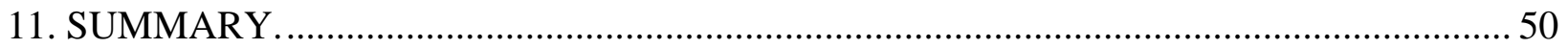




\section{UVOD}

Naslov se kao paratekstna vrsta gotovo uvijek pojavljuje uz umjetnička djela, time i filmove. Za filmski naslov tako mnogi autori ističu da ima istaknutu ulogu u razumijevanju filma u cjelini pri čemu prije svega naglašavaju apelativnu funkciju naslova koja za cilj ima navesti adresata poruke na konzumiranje proizvoda. Budući da se uz tekst filma kao djela za ciljno tržište načelno prevodi i naslov, odlučili smo provesti analizu strategija prevođenja filmskih naslova na hrvatski i njemački jezik. Dosadašnja istraživanja prevođenja filmskih naslova nisu bila opsežna te se uglavnom nisu fokusirala na uvjete odabira pojedinih strategija prevođenja, već na izvore poteškoća pri prevođenju.

Izradili smo dva korpusa sastavljena od originalnih filmskih naslova (uglavnom na engleskom jeziku) i njihovih prijevoda na hrvatski i njemački jezik. U prvome korpusu analizirani su prijevodi 935 filmskih naslova koji su stajali za filmove praizvedene između 1923. i 2016. Prijevodi su kategorizirani prema korištenim strategijama prevođenja. Model strategija prevođenja izrađen je $s$ obzirom na manipulacije značenjskim i/ili specifičnim jezičnim strukturama iz originala. Prvi smo korpus i dijakronijski analizirali kako bismo ustanovili eventualne promjene trendova i pokušali objasniti te promjene. Drugi je korpus korišten za analizu prijevoda naslova romantičnih komedija i horora kako bismo provjerili ima li žanr utjecaj na odabir strategije prevođenja naslova. Iz drugog smo korpusa analizirali prijevode 80-ak originalnih naslova horora i 60 -ak originalnih naslova romantičnih komedija prema istome principu kao i prijevode iz prvog korpusa. Rezultati naše analize sugeriraju razlike u odabiru strategija prevođenja za hrvatsko i njemačko govorno tržište. Dok su naslovi na hrvatski jezik uglavnom izravno prevedeni, najčešća strategija prevođenja za njemačko govorno tržište je prijepis originalnog naslova, a često je i dodavanje struktura koje nisu prisutne u originalu. Analiza naslova romantičnih komedija i horora upućuje da i žanr filma utječe na odabir strategije prevođenja, s razlikama između dvaju tržišta. Većini je neizravnih prijevoda zajedničko pojačano apelativno djelovanje. 


\section{TEORIJSKI PREGLED}

Film se definira kao umjetnički niz slika u pokretu (Jojić, 2015: 296). Uz sam sadržaj filma i drugi njegovi elementi imaju istaknutu ulogu u čovjekovom percipiranju, a time i razumijevanju filma. U načelu je jedan od tih elemenata naslov. Naslov se definira kao paratekstna vrsta. Paratekst označava dodatak glavnome tekstu koji može imati različite funkcije, a često usmjerava čitatelja u interpretaciji djela. Genette u paratekstne vrste ubraja predgovore, pogovore, posvete, napomene, podnaslove i naslove (Genette, 1989: 8-10). Naslovi su uglavnom vizualno prepoznatljivi jer u načelu prethode glavnome tekstu, kratki su te se grafički ističu u odnosu na ostali sadržaj (Iannelli, 1998: 26). Šidiškytė i Tamulaitienè naslove definiraju kao „najistaknutije i najuočljivije dijelove teksta koji s pravom zaslužuju opširniju i sustavniju lingvističku analizu" (Šidiškyte i Tamulaitienè, 2013: 71). Naslovu se tako pridaje značajna komunikacijska uloga kojom on posreduje između adresata teksta kojem pripada i teksta koji naslovljava (Peña-Cervel, 2016: 305).

\section{1. Funkcije naslova}

Prilikom jezičnog izražavanja svaki pošiljatelj obnaša nekoliko jezičnih funkcija. Bühler (1934) u svojem komunikacijskom modelu razlikuje tri istaknute funkcije jezičnog znaka: funkciju predočivanja (Darstellungsfunktion), funkciju izražavanja (Ausdrucksfunktion) i funkciju zazivanja $^{1}$ (Appellfunktion). Dok funkcija predočivanja uspostavlja vezu između jezičnog znaka i referenta u izvanjezičnoj stvarnosti, funkcija izražavanja uspostavlja vezu između realiziranog jezičnog znaka i njegovog pošiljatelja čime se uz sadržaj jezičnog znaka prenose informacije o mentalnom stanju pošiljatelja. Apelativna funkcija potiče adresata na djelovanje, a istaknutu ulogu ima u sadržaju reklamnog karaktera. Prilikom komunikacije prisutne su sve tri funkcije, a jedna od njih uvijek prevladava (Bühler, 1934: 28).

Budući da se Bühlerov komunikacijski model odnosi na opću komunikaciju, pretpostavka je da

${ }^{1} \mathrm{Za}$ funkciju zazivanja nerijetko se koristi i termin apelativna funkcija. 
se može primijeniti i na paratekstne vrste. Nord u svojem teorijsko-analitičkom radu o naslovima razlikuje esencijalne i opcionalne funkcije naslova. U esencijalne funkcije ubraja distinktivnu, metatekstualnu i fatičku. Distinktivna funkcija omogućuje razlikovanje naslova od ostalih naslova u istome kulturno specifičnom korpusu (Nord, 1995: 264). Iannelli napominje da u nekim slučajevima i naslovi trebaju proširak kako bi zadržali distinktivnu funkciju. Kao primjer navodi homonimne književne naslove (npr. Satire, Novele itd.) gdje je potrebno uključiti i autorovo ime. Nadalje, naslovi sličnog izraza mogu uzrokovati interferenciju kod adresata, primjerice naslovi djela Immanuela Kanta Kritik der reinen Vernunft 'kritika čistog razuma' i Kritik der praktischen Vernunft 'kritika praktičnog razuma' (Iannelli, 1998: 31). Metatekstualna funkcija prenosi informacije o žanru budući da se naslovi načelno oblikuju prema žanrovskim konvencijama tržišta za koji se stvaraju ili prevode. Fatičkom se funkcijom uspostavlja komunikacijski kanal i omogućuje konsolidacija primljene poruke (Nord, 1995: 264; KatnićBakaršić, 1999: 3). Fatička se funkcija naslova može uspostaviti i prije nego što je nastalo djelo koje će naslov naslovljavati čime ona ima istaknutu ulogu u održavanju interesa za konzumacijom proizvoda ${ }^{2}$ (Bouchehri, 2008: 30). Ove funkcije naslova Nord naziva esencijalnima jer su one u njenoj analizi univerzalije. U opcionalne funkcije Nord uključuje referencijalnu, ekspresivnu i apelativnu funkciju. Referencijalna funkcija naslova odnosi se na informacije koje se naslovom prenose. Kako bi referencijalna funkcija bila uspješno ostvarena, naslov mora biti razumljiv. Ekspresivnom se funkcijom prenosi konotacija, odnosno izražavaju se mentalna stanja o djelu koje naslov naslovljava. U službi ekspresivne funkcije često su umanjenice, superlativi, glagoli u prvom licu, atributi s istaknutom emotivnom konotacijom, posvojne zamjenice itd. (Nord, 1995: 264; Nord, 2011: 64) Apelativna funkcija, kao i kod Bühlera, potiče adresata na djelovanje (Nord, 1995: 262-265; Nord, 2011: 62-63). Nord navodi da je uz odabir originalnog naslova važan i odgovorajući prijevod na ciljni jezik budući da naslov i na izvornom i na ciljnom tržištu mora ispuniti navedene funkcije, uzimajući u obzir kulturne i specifične jezične čimbenike. Poteškoće pri prevođenju nastaju najčešće tijekom prenošenja referencijalne funkcije (Nord, 2011: 48, 62).

Razni su autori u analizama prevođenja filmskih naslova zaključili da se raznim strategijama prevođenja u ciljni jezik uglavnom nastoji prenijeti apelativno djelovanje naslova (Schubert,

\footnotetext{
2 Böhnke zato napominje da adresat naslova nije samo konzument djela koje naslov naslovljava, već i njegov potencijalni konzument (Böhnke, 2007: 24).
} 
2004; Limon, 2012; Peña-Cervel, 2016; Surdyk i Urban, 2016; Jutronić i Karabatić, 2016). Schubert stoga analizu prevođenja filmskih naslova povezuje s teorijom skoposa (Schubert, 2004: 240). Teorija skoposa predstavlja funkcionalistički pristup prevođenju koji zagovara da je prevođenje proces prijenosa funkcije izraza u izvornom jeziku u ciljni jezik. Pavlović navodi da se teorija skoposa nerijetko kritizirala jer se smatralo da zagovara slobodni prijevod dok ona zapravo ne preferira nijednu strategiju prevođenja. Pavlović zato teoriju skoposa povezuje s načelom cilj opravdava sredstvo (Pavlović, 2015: 193-199).

\section{2. Komercijalna funkcija naslova}

Kao što smo već napomenuli, većina je autora koje smo uzeli u obzir istaknula apelativnu funkciju filmskih naslova u okviru opće komercijalizacije filma. Filmska industrija nastoji ostvariti komercijalni odnosno financijski uspjeh zbog čega se uspješnost pojedinog filma ne mjeri isključivo osvojenim nagradama ili kritikama filmskih stručnjaka, već i ostvarenom dobiti kroz omogućavanje pristupa filmu. Leonardi tvrdi da se pri prevođenju filmskih naslova prije svega nastoji prenijeti apelativna funkcija dok su jezična točnost i kulturna prilagodba u drugom planu. Autorica uvjetno svim komunikacijskim funkcijama naslova pridaje potencijal apelativnog djelovanja (Leonardi, 2011: 10). Leonardi navodi da talijanski prevoditelji odstupaju od originalnog naslova kada je potrebno nadoknaditi učinkovitost apelativne funkcije. Primjerice, u nekim se slučajevima dodaje podnaslov kako bi se gledateljima pojasnilo o kojem se filmskom žanru radi, a na taj se način jača metatekstualno djelovanje naslova (ibid.: 17). Leonardi također spominje tendenciju ubacivanja riječi amore 'ljubav' u talijanske prijevode naslova kako bi se pobudile željena emocionalna stanja adresata, odnosno jača ekspresivna funkcija naslova (ibid.: 14).

U slučajevima gdje je naslov originala čvrsto vezan uz izvornu kulturu ili sadrži igru riječi koja nema ekvivalenta u ciljnom jeziku, mnogi prijevodi ne prenose složenost originalnog naslova već sadržaj nadoknađuju raznim strategijama prevođenja (Limon, 2012: 11). Limon tako navodi niski udio kulturne eksplikacije u slovenskim prijevodima engleskih originalnih naslova (ibid.: 5). Stoga govori i o kulturnoj neutralizaciji odnosno dekulturalizaciji filmskih naslova (ibid.: 10). Schubert u svojoj studiji napominje da se kod prevođenja filmskih naslova isključivo radi o 
prijenosu apelativnog djelovanja (Schubert, 2004: 241).

\section{3. Povijest i stanje istraživanja}

Istraživanja naslova, također titrologija, sežu sve do 18. stoljeća, a titrologija je kao disciplina u lingvistici utemeljena nastankom tekstne lingvistike u 1970-ima. Prvi radovi o naslovima najvećim su dijelom obrađivali naslove književnih djela, naročito romana. Tek se poneki autori osvrću na filmske naslove i to uglavnom iz poredbene perspektive. Pritom su autori uspoređivali književne i filmske naslove ili općenito naslove umjetničkih djela s naslovima znanstvenih radova (Bouchehri, 2008: 33). Slike, glazbena djela i filmovi u sedamdesetim godinama nisu bili predmetom komunikacijskih znanosti, zbog čega su naslovi ovih tekstnih vrsta počeli buditi sve veći interes (ibid.: 34). Međutim, i dalje nedostaju opsežna i sustavna istraživanja: „,(..) teorijska su istraživanja metoda prevođenja naslova oskudna" (Peña-Cervel, 2016: 307). Dosadašnje analize prevođenja filmskih naslova mogu se podijeliti na azijski i europski geografsko-kulturni krug. Azijski su autori uglavnom bili usredotočeni na strategije podomaćivanja (domestication) i postranjivanja (foreignization) (Yin, 2009; Shi, 2014; Mei, 2010), a posebno su obrađivali i transliteraciju zbog razlike u korištenim pismima između dominantnog izvornog tržišta, Sjedinjenih Američkih Država ${ }^{3}$, i ciljnog azijskog tržišta (Yin, 2009: 171-172). Europski su se autori u svojim istraživanjima uglavnom usredotočili na izvore poteškoća pri prevođenju filmskih naslova referirajući se i na određene strategije prevođenja (Schubert, 2004; Leonardi, 2011; Limon, 2012; Berdis, 2013; Šidiškytè i Tamulaitienè, 2013; Jutronić i Karabatić, 2016; Surdyk i Urban, 2016). Limon (2012) te Surdyk i Urban (2016) kao razloge za istraživanje prevođenja filmskih naslova navode česte kritike prijevoda naslova filmova i televizijskih serija.

Gotovo sve analize bile su usredotočene na jedno izvorno i jedno ciljno tržište, a samo su Šidiškytė i Tamulaitienė (2013) provele poredbenu analizu prijevoda engleskih filmskih naslova na litavski i ruski jezik. Jutronić i Karabatić (2016) su provele, prema našem saznanju, jedinu studiju koja je u analizu uključila prijevode filmskih naslova na hrvatski jezik. Autorice su analizirale izvore poteškoća u prevođenju filmskih naslova koncentrirajući se na fonetsku igru,

3 „Sjedinjene Američke Države dominiraju svjetskim filmom i filmskom industrijom i to ne samo u zadnja dva desetljeća." (Beier i dr., 1994: 5, prema Schubert, 2004: 240). 
igru riječi, moguće višeznačne interpretacije, referencije, idiome i intertekstualnost u originalnim naslovima. Autorice zaključuju da se fonetska igra, igra riječi i intertekstualnost uglavnom ne sačuvaju u hrvatskim prijevodima. Nadalje, primjećuju da više od polovice hrvatskih neizravnih prijevoda iz njihovog korpusa ne može opravdati korištenu strategiju nemogućnošću prijenosa značenjskih i/ili specifičnih jezičnih struktura zbog čega pretpostavljaju istaknutu ulogu distributera u prevođenju filmskih naslova radi jačanja apelativne funkcije naslova (ibid.: 101102).

Negro Alousque (2015) i Peña-Cervel (2016) provele su uvjetno rečeno kognitivne analize strategija prevođenja filmskih naslova s engleskog na španjolski i francuski jezik odnosno $\mathrm{s}$ engleskog na španjolski jezik. Negro Alousque analizirala je korpus od 100 originalnih naslova i njihovih prijevoda i zaključila da se uz izravne prijevode i prijepise filmskih naslova mogu pronaći prijevodi koji se mogu objasniti djelovanjem nekih kognitivnih mehanizama. Pozivajući se na teoriju idealiziranih kognitivnih modela ${ }^{4}$ Peña-Cervel analizirala je korpus od ,približno 500” engleskih naslova i njihovih španjolskih prijevoda, uzevši pritom u obzir samo neizravne prijevode. Pretpostavka autorice bila je da i kod neizravnih prijevoda, unatoč ponekad značajno manjoj sadržajnoj povezanosti s originalom, postoje kognitivni mehanizmi koji sudjeluju u prevođenju te povezuju original i prijevod $\mathrm{u}$ istom idealiziranom kognitivnom modelu. PeñaCervel zaključuje da su najčešći kognitivni mehanizmi u primjerima iz istraženog korpusa bili metonimija, generalizacija i specijalizacija ${ }^{56}$ (ibid.: 313). Rezultati studije sugeriraju da su i neizravni prijevodi naslova uglavnom sadržajno povezani s originalom jer se odnose na isto djelo čiji sadržaj teksta oblikuje idealizirani kognitivni model. No same poveznice između originala i prijevoda u studiji podložne su subjektivnoj procjeni te je teško odrediti koliko su one bile relevantne tijekom prevođenja.

\footnotetext{
${ }^{4}$ Idealizirani kognitivni modeli predstavljaju strukture u umu koje služe kao osnovica za razumijevanje drugih struktura, a koje se same sastoje od koncepata. Stanojević navodi primjer koncepta vjetrobran koji se može razumijeti samo ako se razumije unutar domene vozilo (Stanojevič, 2013: 73).

${ }^{5}$ Metonimija označava promjenu značenja koja se temelji na bliskosti između dvaju koncepata koji su dio iste kognitivne domene (Ravlić, 2006: 589). Autorica navodi primjer naslova filma Bullet to the Head 'metak u glavu' (Hill, 2012) koji je na španjolski preveden kao Una bala en la cabeza 'metak u glavi' čime rezultat radnje stoji za radnju. Kao primjere generalizacije i specijalizacije autorica navodi The Texas Chainsaw Massacre 'teksaški masakr motornom pilom' (Nispel, 2003) > La matanza de Texas 'teksaški masakr' odnosno Babe (Noonan, 1995) > Babe, el cerdito valiente 'Babe, hrabri praščić'. Više o navedenim kognitivnim mehanizmima u Raffaelli (2009), 160-169.

${ }^{6}$ Autorica napominje da je u većini slučajeva više kognitivnih mehanizama sudjelovalo u oblikovanju prijevoda filmskih naslova (Peña-Cervel, 2016: 313).
} 
Rojo i Ibarretxe-Antuñano (2013) navode pet ključnih točaka koje će odrediti budući smjer translatološke analize: redefiniranje pojma ekvivalencije i procesa gradbe značenja, pitanje konteksta i kulture kako bi se premostile razlike između književnog i lingvističkog pristupa, otkrivanje kognitivnih operacija važnih pri odabiru prijevodnih strategija u procesu rekonstrukcije značenja (process of recreating meaning), stvaranje novih metoda i vrednovanje utjecaja prevoditeljevih dvojezičnih kompetencija na gotov prijevod (Rojo i Ibarretxe-Antuñano, 2013: 10).

\section{4. Kontekst prevođenja naslova}

U procesu prevođenja filmova ne pristupa se na jednak način tekstu filma kao djela i njegovom naslovu. Dok tekst u načelu prevode prevoditelji, u prevođenje naslova često su uključeni i distributeri, upravo zbog istaknute apelativne funkcije naslova.

Jutronić i Karabatić zaključile su da se kod prevođenja naslova na hrvatski jezik koriste brojne strategije prevođenja koje autorice izjednačavaju s marketinškim strategijama navodeći primjer dodavanja struktura povezanih s radnjom filma, a kojih u originalu nema. Autorice zbog toga pretpostavljaju istaknutu apelativnu funkciju naslova i ulogu distributera koji naslov prilagođavaju s ciljem jačanja navedene funkcije (Jutronić i Karabatić, 2016: 103). Dok je funkcija titlova ili sinkronizacije omogućiti ciljanoj publici razumijevanje filma na stranom jeziku, funkcija je naslova privući publiku. Jutronić i Karabatić tako prijepise originalnih naslova na engleskom jeziku za hrvatsko govorno tržište objašnjavaju prestižnim statusom engleskog jezika u hrvatskoj govornoj zajednici (ibid.: 87). Limon navodi da distributeri na slovenskom govornom tržištu nastoje biti uključeni u sve aspekte komercijalizacije filma na ciljnom tržištu. Također napominje da naslove kinofilmova uglavnom prevode distributeri dok je u slučaju prikazivanja na televiziji za prijevod zadužena televizijska kuća koja je otkupila prava za film (Limon, 2012: 8). Peña-Cerval piše o problemu statusa prevoditelja kod prevođenja filmskih naslova jer to u načelu ne čine profesionalni prevoditelji, već distributeri zbog čega prevedeni naslovi često nisu u skladu s prevoditeljskom normom (Peña-Cerval, 2016: 307). Limon kao jedan od čimbenika u prevođenju filmskih naslova navodi i postojanje književnog predloška. U tim slučajevima uglavnom se preuzima već prevedeni naslov književnog djela (Limon, 2012: 9). 
Na odabir prijevoda naslova mogu utjecati i prijevodi na druge ciljne jezike. Limon tako navodi utjecaj njemačkih prijevoda naslova na slovenske pri čemu se njemački prijevodi izravno prevode na slovenski jezik (ibid.: 9). Ovakve slučajeve Šidiškytė i Tamulaitienè nazivaju imitativnim prijevodima ograničavajući ih na izrazom jednake ili vrlo slične prijevode naslova na dvama jezično različitim tržištima, a koji su nastali neizravnim strategijama prevođenja. Autorice navode primjer naslova filma Arbitrage 'arbitraža' (Jarecki, 2012) koji je na litavski preveden kao Apgaulinga aistra 'varljiva strast' te na ruski kao Порочная страсть 'poročna strast' pri čemu autorice pretpostavljaju utjecaj ruskog prijevoda na litavski (Šidiškytė i Tamulaitienè, 2013: 75).

Kako bismo provjerili koji čimbenici utječu na prijevod filmskih naslova i kakva je uloga profesionalnih prevoditelja u Hrvatskoj, razgovarali smo s voditeljicom Službe za prijevode Hrvatske radiotelevizije Branimirom Borčić Nemec. Borčić Nemec napominje da prevoditelj često nema utjecaj na prijevod filmskog naslova. Ipak, postoji razlika između filmova koji se prevode za prikazivanje u kinima, a čije naslove prevode distributeri i filmova koji se prevode za prikazivanje na televiziji. Na Hrvatskoj radioteleviziji prevoditelj sudjeluje u svim fazama prevođenja filma ili serije, uključujući i odabir prijevoda naslova. Tako prevoditelj nakon prijevoda teksta filma daje svoje prijedloge za prijevod naslova, a urednik odabire jedan od tih prijedloga. Osim prevoditelja i urednika u procesu prevođenja na HRT-u uvijek sudjeluje i lektor čime se nastoji podići kvaliteta prijevoda. Borčić Nemec navodi da HRT ima pravila rada za prevođenje filmova i serija. Prevoditelji na državnoj televiziji tako teže normativnoj točnosti naslova te izbjegavanju stranih riječi, osim ako se radi o naslovima koji u sebi sadrže toponime i slično, kao primjerice serija Downton Abbey (Fellowes, 2010-2015) koja se na hrvatskoj televiziji prikazivala pod originalnim naslovom. Naslov se nastoji prevesti „u duhu hrvatskog jezika“", a ako postoji mogućnost, prevoditelj će se odlučiti za igru riječi u naslovu kako bi film ili serija privukli što više gledatelja. Istovremeno, prevoditelj nastoji ostati što vjerniji originalnom naslovu i vodi računa o povezanosti prijevoda naslova sa sadržajem filma. Borčić Nemec ovdje navodi primjer serije The Astronaut Wives Club (Savage, 2015) čiji je naslov u hrvatskom prijevodu Supruge astronauta čime glavna tema ostaje razvidna u naslovu, kao što je to u originalu. Nadalje, prevoditelj na HRT-u ima pravo intervenirati u već postojeći prijevod naslova ako se film prikazivao u kinu prije nego što je televizija otkupila prava za njegovo prikazivanje. Ako prevoditelj smatra da naslov nije valjano preveden, može ga promijeniti uz 
odobrenje urednika. Kao iznimku Borčić Nemec navodi filmove koji se nalaze u Filmskoj enciklopediji Leksikografskog zavoda Miroslav Krleža, a čiji se naslovi načelno ne mijenjaju.

Situaciju na njemačkom govornom tržištu provjerili smo u razgovoru s Henningom Bochertom iz prevoditeljske agencije Bochert Translations u Berlinu. Bochert navodi kako kao prevoditelj igranih filmova za Netflix dosad nije imao utjecaj na prevođenje naslova jer je iz njegovog dosadašnjeg iskustva prijevod naslova pod utjecajem marketinga. Uspoređujući prijevode filmskih naslova, odnosno korištene prijevodne strategije u Njemačkoj prije 1980-ih i danas, naslovi su se ranije mnogo češće izravno ili slobodno prevodili. Danas se naslovi češće ostavljaju u originalu kada se radi o filmovima na engleskom jeziku. Osim toga, raširena je i strategija proširenog naslova koji uz originalni naslov na engleskom imaju i proširak na njemačkom jeziku. Bochert ovu strategiju povezuje s marketingom budući da proširak ima ulogu slogana za film, ali i, kako sam navodi, težnjom da se uspostavi ravnoteža između velikog utjecaja engleskog jezika u Njemačkoj i statusa njemačkog kao službenog i nacionalnog jezika. Budući da se strani filmovi u Njemačkoj uglavnom sinkroniziraju, gledateljima ovakva strategija nije neobična jer se u usporedbi sa sinkronizacijom cijelog filma, iz perspektive gledatelja, radi o manjoj prevoditeljskoj intervenciji. Bochert spominje i ulogu filmskih studija u odabiru strategije prevođenja koji ponekad zahtijevaju da se naslov filma ostavi u originalu što distributeri i ostali akteri moraju poštovati. Kao na HRT-u i u Njemačkoj se, ako je moguće, poseže za igrom riječi. Bochert ovdje kao primjer navodi film Out of the Furnace 'iz peći' (Cooper, 2013) koji je na njemački preveden izrazom Auge um Auge 'oko za oko'. Budući da je originalni naslov referencija na industriju i engleski izraz out of the furnace, into the fire koji označava prijelaz iz loše u goru situaciju, a za koji u njemačkom jeziku ne postoji ekvivalent, naslov je preveden drugačije, ali je u njemu zadržana poveznica sa žanrom filma (triler). Televizija u Njemačkoj ima utjecaj na filmske naslove pa ih kao i u Hrvatskoj ima pravo promijeniti, čak i ako se film prije toga već prikazivao u kinima. Bochert ovdje navodi naslov filma The Astronaut's Wife 'astronautova žena' (Ravich, 1999) koji je u Njemačkoj imao dva prijevoda, jedan za prikazivanje u kinima (Die Frau des Astronauten 'žena astronauta') i drugi za televiziju (Die Frau des Astronauten - Das Böse hat ein neues Gesicht 'žena astronauta - zlo ima novo lice'). Prvi naslov je izravni prijevod originala dok drugi uz izravan prijevod ima i proširak. Proširak naslova daje dodatne informacije o žanru i radnji filma te ispunjava svoju marketinšku funkciju slogana kojom se nastoji privući veći broj gledatelja. 
Kako bismo provjerili kako distributeri odlučuju o prijevodu naslova filmova, razgovarali smo s Timmom Oberwellandom iz nezavisne distributerske tvrtke TOBIS Film GmbH sa sjedištem u Berlinu. Tvrtka se bavi distribucijom njemačkih i stranih filmova koji se prikazuju u Austriji, Njemačkoj i Švicarskoj. O naslovu odlučuje marketinški odjel tvrtke u kojemu nema zaposlenih prevoditelja što potvrđuje da profesionalni prevoditelji nemaju istaknutu ulogu u procesu prevođenja naslova. Kako objašnjava Oberwelland, tvrtka otkupljuje prava za prikazivanje filmova na 15 do 20 godina. Licencija vrijedi za prikazivanje putem svih distribucijskih kanala: kina, televizije i interneta, a godišnje se otkupi 15 filmova. U ugovoru koji tvrtka potpisuje s filmskim kućama određuju se svi aspekti komercijalizacije filma na novom tržištu: filmski plakat, proračun za promidžbu i naslov filma, što znači da se davatelji licencije moraju složiti s odabranim plakatom i naslovom. Distributeri su uz to odgovorni i za podnaslovljavanje odnosno sinkronizaciju za njemačko tržište, a taj dio posla odrađuju prevoditelji zaposleni kao vanjski suradnici. U protekloj su godini filmske naslove preveli koristeći strategije transkreacije [npr. Viceroy's House 'upraviteljeva kuća' (Chadha, 2017) > Der Stern von Indien 'zvijezda Indije'], izravnog prijevoda [npr. Paris Can Wait 'Pariz može čekati' (Coppola, 2016) > Paris kann warten] i prijepisa [npr. Bad Moms 'loše mame' (Lucas, Moore, 2016) > Bad Moms]. Utjecaj engleskog jezika na njemačkom tržištu povezan je s društvenim mrežama na kojima gledatelji često prvi put dođu u kontakt s filmom, a time i filmskim naslovom na izvornom jeziku (načelno engleskom). Stoga distributeri ponekad odluče zadržati izvorni engleski naslov jer bi njegovo prevođenje bilo loš marketinški potez, posebno kada se radi o filmovima koji su zbog primjerice osvajanja nagrade Oscar bili zastupljeni u stranim i njemačkim medijima. Oberwelland navodi primjer filma Twelve Years a Slave '12 godina rob' (McQueen, 2013) koji se na njemačkom govornom tržištu prikazivao pod istim naslovom jer su distributeri smatrali da je apelativna funkcija jača kod izvornog naslova. Utjecaj na odabir naslova ima i postojanje književnog predloška. Ako je film snimljen prema knjizi koja je prije toga prevedena na njemačkom jeziku, distributeri će preuzeti naslov knjige, kao što je slučaj kod naslova filma P. S. I Love You 'P. S. volim te' (LaGravenese, 2007) koji je na njemačkom govornom tržištu glasio $P$. S. Ich liebe dich 'P. S. volim te'. U prevođenju naslova distributeri nastoje prenijeti i ako je moguće pojačati apelativnu funkciju. Oberwelland tako spominje film The Last Word 'posljednja riječ' (Pellington, 2017) čiji naslov nije izravno preveden na njemački, iako je to bilo moguće, već se prikazivao pod naslovom Zu guter Letzt ‘i za kraj’. Odluka o promjeni naslova donesena je jer bi 
izravni prijevod ima negativnu konotaciju završetka koja stvara mentalnu sliku posljednjeg dijela niza, dok je njemački naslov pozitvnije konotiran jer označava samo kraj zaokružene cjeline. Marketniška funkcija naslova određuje uspjeh filma na tražištu pa se može dogoditi da film na stranom tržištu ostavari veći uspjeh nego na izvornom zahvaljujući eksplicitnijem naslovu, što pokazuje film A Little Chaos 'malo kaosa' (Rickman, 2014) koji je bio komercijalno uspješniji na njemačkom tržištu što Oberwelland povezuje s transkreacijom naslova u Die Gärtnerin von Versailles 'vrtlarica iz Versaillesa' koja eksplicitnije izražava radnju filma i osnažuje apelativno djelovanje naslova.

\section{5. Pitanje definicije prijevoda}

Gotovo svi autori koji su analizirali prevođenje filmskih naslova zaključili su da prijevod naslova za ciljno tržište ne treba biti ni djelomično značenjski ekvivalentan s originalom da bi bio funkcionalan (Schubert, 2004; Leonardi, 2011; Limon, 2012; Šidiškytè i Tamulaitienè, 2013; Jutronić i Karabatić, 2016; Surdyk i Urban, 2016; Peña-Cervel, 2016). Takvo ponašanje naslova protivi se tzv. zakonu standardizacije koji čini prijevodnu univerzaliju. Zakon standardizacije opisuje tendenciju prilagođavanja prijevoda ciljnoj publici te zamjenu specifičnih tekstualnih veza prisutnih u izvornom jeziku konvencionalnim vezama provodeći postupak normalizacije (Baker, 1998: 290). Stoga su se neki autori u kontekstu filmskih naslova bavili i pitanjem statusa odnosno definicije prijevoda. Schubert umjesto o prevođenju naslova govori o interkulturnom transferu tzv. procesom novonaslovljavanja (Neubetitelung) koji obuhvaća dvije glavne kategorije: prijevode i neprijevode. U kategoriju prijevoda ubraja sve prijevode kod kojih je prisutna barem djelomična značenjska ekvivalencija s originalom, a unutar te kategorije razlikuje doslovne i slobodne prijevode, ovisno o stupnju značenjske i/ili specifične jezične ekvivalencije (Schubert, 2004: 241-242). Prema tome, iako Schubert proizvode određenih strategija prevođenja klasificira kao prijevode u užem smislu, svaki naslov koji je prošao neku strategiju prevođenja naziva novim naslovom (Neutitel). Limon (2012) također koristi pojam kulturnog transfera za sve strategije prevođenja filmskih naslova.

Za potrebe ove analize prijevod ćemo definirati u širem smislu kao svaki prijenos filmskog naslova s izvornog na ciljno tržište, neovisno o stupnju značenjske ekvivalencije s originalom. 


\section{HIPOTEZE I CILJEVI RADA}

Opći je cilj istraživanja analizirati strategije prevođenja filmskih naslova za hrvatsko i njemačko govorno tržište.

Specifični su ciljevi rada: (1) usporediti odabir strategija prevođenja filmskih naslova za hrvatsko i njemačko govorno tržište, (2) utvrditi eventualne dijakronijske promjene u odabiru strategija prevođenja filmskih naslova za hrvatsko i njemačko govorno tržište, (3) utvrditi načine jačanja apelativnog djelovanja filmskih naslova i njihovih prijevoda te (4) utvrditi ima li žanr filma utjecaj na oblikovanje naslova odnosno njegovog prijevoda.

Iz navedenih ciljeva istraživanja proizlaze sljedeće hipoteze:

(1) Odabir strategija prevođenja filmskih naslova razlikuje se na hrvatskom i njemačkom govornom tržištu.

(2) Dijakronijski se na obama tržištima povećavao udio prijepisa, a smanjivao udio izravnih prijevoda.

(3) Filmski naslovi na obama tržištima imaju istaknutu apelativnu funkciju.

(4) Žanr filma na obama tržištima utječe na odabir strategija prevođenja filmskih naslova. 


\section{MATERIJALI I METODE}

Za potrebe studije izrađena su dva dvodijelna korpusa: uvjetno rečeno opći i specifični. Jedan dio općeg korpusa sastojao se od 935 originalnih filmskih naslova na različitim jezicima, a drugi od prijevoda tih naslova na hrvatski (917) i njemački (914) jezik ${ }^{7}$. Originalni naslovi uglavnom su bili na engleskom jeziku ${ }^{8}$ što je bio slučaj i u svim dosad provedenim studijama koje smo uzeli u obzir (Schubert, 2004; Mei, 2010; Leonardi, 2011; Limon, 2012; Berdis, 2013; Šidiškytė i Tamulaitienė, 2013; Negro Alousque, 2015; Jutronić i Karabatić, 2016; Surdyk i Urban, 2016; Peña-Cervel, 2016). Kao izvor za originalne filmske naslove poslužila nam je internetska stranica IMDb-a (Internet Movie Database; imdb.com), online baza podataka koja nudi relevantne informacije o filmovima, televizijskim emisijama i videoigrama. I druge su studije koristile IMDb u izradi korpusa ${ }^{9}$ (Schubert, 2004; Berdis, 2013; Surdyk et Urban, 2016; PeñaCervel, 2016). Odabrali smo razdoblje od 1923. do 2016. kako bismo mogli napraviti i dijakronijsku analizu, a iz svake je godine preuzeto 10 originalnih naslova koji su imali najveći broj dodijeljenih ocjena ${ }^{10}$. Većina prijevoda naslova na hrvatski jezik izvučena je iz online izdanja Filmskog leksikona Leksikografskog zavoda Miroslav Krleža (film.lzmk.hr) te s internetskih stranica filmski.net, mojtv.hr, moj-film.hr i blitz-cinestar.hr. Stranice mojtv.hr i mojfilm.hr koristile su i Jutronić i Karabatić (2016) u pronalaženju hrvatskih prijevoda naslova. Prijevode na njemački jezik pronalazili smo na internetskim stranicama moviepilot.de i cineplex.de. Korpusna analiza uključivala je podjelu prijevoda naslova s obzirom na korištene strategije prevođenja. Preuzet je model strategija prevođenja koji je u svojoj analizi koristio Schubert (2004), no uz određene preinake. Strategije prevođenja definirane su s obzirom na tip manipulacije specifičnim jezičnim i/ili značenjskim strukturama pri prevođenju naslova. Strategije na koje ćemo se pozivati u korpusnoj analizi su:

\footnotetext{
${ }^{7}$ Neki se filmovi nisu prikazivali na hrvatskom odnosno njemačkom govornom tržištu pa za neke naslove nismo pronašli prijevode. Nadalje, neki su originalni naslovi već bili na njemačkom jeziku. Nije bilo originalnih naslova na hrvatskom jeziku. Svaki originalni naslov je bio preveden barem na jedan jezik.

${ }^{8}$ Ostali jezici su, od najzastupljenijeg prema najmanje zastupljenom, francuski (30), talijanski (15), njemački (15), japanski (14), ruski (6), švedski (4), španjolski (3), latinski (1), korejski (1), hindski (1), portugalski (1) i danski (1).

9 Surdyk i Urban navode IMDb kao ,najpopularniji i najrelevantniji izvor informacija o filmovima, televiziji i poznatim osobama" (Surdyk i Urban, 2016: 157).

10 Odabrali smo ovaj kriterij jer smo pretpostavili korelaciju između broja ocjena dodijeljenih filmu na IMDb-u i njegove konzumiranosti.
} 
1. izravni prijevod [npr. The Sixth Sense (Night Shyamalan, 1999) > Šesto čulo] - Izravni prijevod je prijevod koji je značenjski gotovo ekvivalentan originalu ${ }^{11}$. Schubert napominje da izravni prijevod u pravilu implicira da prevoditelj nije naišao na kulturne odnosno specifične jezične komplikacije (ibid.: 242). Međutim, i kod izravnih prijevoda mogu se zbog općih kulturnih i sličnih razlika između izvornog i ciljnog tržišta izgubiti asocijacijske veze. Schubert navodi primjer američkog filma The Color of Money 'boja novca' (Scorsese, 1986) koji je za njemačko govorno područje izravno preveden kao Die Farbe des Geldes pri čemu se izgubila asocijacija na zelenu boju koja obilježava američki dolar, no ne i euro odnosno švicarski franak (ibid.: 242). Analize prevođenja filmskih naslova nisu uvijek uključivale izravne prijevode, uglavnom jer su se autori odlučili analizirati izvore poteškoća u prevođenju.

2. slobodni prijevod - Slobodni prijevod je prijevod koji je prošao određene modifikacije, no djelomično je zadržao značenjsku ekvivalenciju. Modifikacije jednog dijela originala uključuju dodavanje, oduzimanje, zamjenu i pomak. Limon napominje da su neke modifikacije minorne te da ne stvaraju nužno veće apelativno djelovanje (Limon, 2012: 9).

a. dodavanje [npr. Dawn of the Dead 'zora mrtvaca' (Snyder, 2004) > Zora živih mrtvaca] - Dodavanje se odnosi na umetanje struktura u prijevod koje u originalu nisu prisutne. Schubert smatra da se dodavanjem pri prevođenju na njemački jezik najčešće umeću atributi s istaknutijom emotivnom konotacijom i imena likova u slučaju serijala ${ }^{12}$ (Schubert, 2004: 245). ${ }^{13}$

b. oduzimanje [npr. Everything You Always Wanted to Know About Sex * But Were Afraid to Ask 'sve što ste ikada željeli znati o seksu, ali ste se bojali pitati' (Allen, 1972) > Sve što ste željeli znati o seksu] - Oduzimanjem se iz originala pri prevođenju djelomično uklanjaju strukture. Schubert navodi dva primjera s

\footnotetext{
11 Pavlović napominje da je apsolutna značenjska ekvivalencija između dvaju jezika neostvariva odnosno da je nemoguće reproducirati prijevod koji je u cijelosti vjeran originalu (Pavlović, 2015: 46).

12 Schubert smatra da se isticanjem pripadnosti filma serijalu pojačava apelativno djelovanje naslova zbog tzv. efekta serije (Serieneffekt), ,vjerovanja potrošača da novi proizvodi iz iste skupine imaju konstantno visoku kvalitetu" (Schubert, 2004: 247).

13 Schubert u slobodne prijevode $\mathrm{s}$ dodavanjem uključuje i naslove koji su ostavljeni u identičnom obliku kao original, no s dodatkom podnaslova koji sam predstavlja izravni ili slobodni prijevod originala, npr. Signs 'znakovi' (Night Shyamalan, 2002) > Signs - Zeichen (Schubert, 2004: 245). U ovoj će se studiji tako opisani naslovi klasificirati drugačije.
} 
oduzimanjem kod kojih je ono bilo potaknuto dugačkim, nepreglednim naslovima, npr. Who Is Harry Kellerman and Why Is He Saying Those Terrible Things About Me? 'tko je Harry Kellerman i zašto govori te strašne stvari o meni?' (Grosbard, 1971) > Wer ist Harry Kellerman? 'tko je Harry Kellerman?' (ibid.: 242-243).

c. pomak [npr. To Catch a Thief 'uhvatiti lopova' (Hitchcock, 1955) > Uhvatite lopova] - Pomak smo za potrebe ove studije definirali kao odstupanje od morfosintaktičkih struktura u prijevodu u odnosu na original, a koje ne predstavlja premošćivanje razlika u strukturama dvaju jezičnih sustava ${ }^{14}$. Schubert piše da se pomakom u njemačkim prijevodima filmskih naslova može ostvariti nedorečenost koja jača apelativno djelovanje, npr. The Postman Always Rings Twice 'poštar uvijek zvoni dvaput' (Rafelson, 1981) > Wenn der Postmann zweimal klingelt 'kad poštar dvaput zazvoni', te izraziti veća dinamika radnje, npr. Ferris Bueller's Day Off 'slobodan dan Ferrisa Buellera' (Hughes, 1986) > Ferris macht blau 'Ferris markira' (ibid.: 244).

d. zamjena [npr. House on Haunted Hill 'kuća na ukletom brdu' (Castle, 1959) > Kuća straha] - Kod zamjene jedan je dio originala izravno preveden dok je drugi zamijenjen nekim drugim izrazom. Schubert određuje da je kod zamjene sintaktička struktura prijevoda jednaka onoj originala ${ }^{15}$. Nadalje, zaključuje da su tipični supstituti konkretniji leksemi i leksemi s istaknutijom emotivnom konotacijom koji osnažuju apelativno djelovanje naslova. Međutim, spominje i primjer zamjene u službi kulturne neutralizacije: The Bridges of Madison County 'mostovi okruga Madison' (Eastwood, 1995) > Die Brücken am Fluss 'mostovi na rijeci' (ibid.:: 243).

3. transkreacija ${ }^{16}$ [npr. American Beauty 'američka ljepota' (Mendes, 1999) > Vrtlog života] - Transkreacija predstavlja potpunu zamjenu nakon koje nema struktura u prijevodu koje su izrazom i značenjem ekvivalentne onima u originalu. Dok se izraz naslova može mijenjati bez narušavanja cjelovite strukture kojoj pripada, referent uvijek

\footnotetext{
${ }^{14}$ Pavlović stoga razlikuje obvezne i neobvezne (opcionalne, moguće) pomake (Pavlović, 2015: 53).

15 Takva se izjava doduše može interpretirati na različite načine, no u slučaju da je uz zamjenu došlo i do pomaka, prijevod se klasificirao u mješoviti tip slobodnog prijevoda.

${ }^{16}$ Termin je preuzet iz Šidiškyte i Tamulaitienè (2013) (transcreation).
} 
ostaje isti (ibid.: 246). Schubert razlikuje obveznu i neobveznu transkreaciju. Dok se neki, primjerice idiomatični, naslovi moraju transkreirati jer ne postoji zadovoljavajući ekvivalent u ciljnom jeziku, neki se naslovi transkreiraju kako bi imali jače apelativno djelovanje. U nekim je slučajevima i teško reći na koji bi se način neke značenjske strukture prenijele iz izvornoga u ciljni jezik, naročito u slučaju moguće višeznačne interpretacije (Limon, 2012: 6). Schubert navodi da su njemački transkreirani naslovi eksplicitnijeg sadržaja nego originali ${ }^{17}$ (Schubert, 2004: 246-247). Limon također navodi značajan udio eksplikacije u slovenskim neizravnim prijevodima engleskih naslova, 41,3 \%, određujući identificiranje žanra kao najčešći cilj eksplikacije (Limon, 2012: 4). Nadalje, transkreacije na njemački jezik pokazuju tendenciju personalizacije, npr. First Blood 'prva krv' (Kotcheff, 1982) > Rambo ${ }^{18}$, i uporabu leksema s istaknutijom emotivnom konotacijom čime se, kako Schubert navodi, želi postići emotivna identifikacija ciljne skupine sa sudbinama likova (Schubert, 2004: 247-248). Surdyk i Urban navode da su transkreacije uglavnom u službi jačanja apelativnog djelovanja (Surdyk i Urban, 2016: 168). Peña-Cervel je svojom kognitivnom analizom prevođenja engleskih naslova na španjolski jezik ustanovila da se naslovi prevode unutar određenih idealiziranih kognitivnih modela stvorenih radnjom filma što sugerira nužnu značenjsku vezu između originala i prijevoda (Peña-Cervel, 2016: 333).

4. prijepis - Prijepis se odnosi na zadržavanje struktura iz originala u prijevodu uz eventualne modifikacije. Jutronić i Karabatić navode da se distributeri za hrvatsko govorno tržište nerijetko odlučuju za prijepis engleskog originala zbog pretpostavke prestiža engleskog jezika među govornicima hrvatskog jezika. Jedan od primjera koji navode je The Matrix 'matrica' (Wachowski, Wachowski, 1999) > Matrix (Jutronić i Karabatić, 2015: 87).

a. potpuni prijepis [npr. Spider-Man ${ }^{19}$ (Raimi, 2002) > Spider-Man] - Potpuni prijepis predstavlja identični izraz naslova u originalu i njegovu prijevodu. Za potrebe studije u potpune prijepise uključili smo i transkripciju, npr. Anna

\footnotetext{
17 Schubert svoja zapažanja povezuje s rezultatima kontrastivne analize njemačkog i engleskog diskursa House (1996). House primjećuje da su njemački ispitanici „eksplicitnije započinjali temu“. Međutim, House je razlike u diskursu obradila iz perspektive percepcije govornika koji su, kako navodi House, njemačke strategije diskursa uglavnom ocijenili „neljubaznima“, ,agresivnima“ i sl. (ibid.: 346, 354).

${ }^{18}$ Rambo je prezime i nadimak glavnog lika.

${ }^{19}$ Spider-Man je ime lika.
} 
Karenina (Brown, 1935) > Ana Karenjina. Schubert razlikuje četiri skupine potpunog prijepisa u njemačkim prijevodima. Prvu skupinu čine imena ${ }^{20}$, najčešće likova i mjesta, čija je referencija jednoznačna. Drugu skupinu čine homografski naslovi i njihovi prijevodi, a treću i četvrtu razlikuje prema stupnju složenosti vokabulara na stranom jeziku (Schubert, 2004: 251-253).

b. dodavanje [npr. Octopussy ${ }^{21}$ (Glen, 1983) > James Bond: Octopussy] - Schubert navodi da se originalnim naslovima uglavnom dodaju podnaslovi. Podnaslovi mogu imati primarnu ulogu davanja novih, konkretnijih informacija o sadržaju filma, no mogu biti i „,značenjski relativno prazni” služeći za jačanje apelativnog djelovanja. Schubert potonje naslove naziva nonsens-podnaslovima (NonsensUntertitel), a pronalazi ih prije svega u mainstream komedijama (ibid.: 249-251).

c. oduzimanje [npr. The Karate Kid (Avildsen, 1984) > Karate Kid] - Schubert napominje da se oduzimanje u slučajevima prijepisa rijetko pojavljuje (ibid: 251).

d. zamjena [npr. Pirates of the Caribbean: Dead Man's Chest 'pirati s Kariba: mrtvačeva škrinja' (Verbinski, 2006) > Pirates of the Caribbean - Fluch der Karibik 2 'pirati s Kariba - prokletstvo Kariba 2,22] - Schubert i za prijepise sa zamjenom navodi da su rijetki (ibid.: 251).

Neki su autori u svojim analizama primijetili prijevode koji su bili oblikovani pogrešnim razumijevanjem originala (Limon, 2012; Surdyk i Urban, 2016). Limon navodi primjer filma Mystic River (Eastwood, 2003) koji je na slovenski jezik preveden kao Skrivnostna reka 'tajanstvena rijeka' pri čemu je Mystic River naziv stvarne rijeke koja teče Bostonom, mjestom radnje filma (Limon, 2012: 8). Međutim, mi u našu analizu nismo uključili kategoriju pogrešnih prijevoda budući da bi bilo teško ustanoviti jasne kriterije za razlikovanje pogrešnog prevođenja od strategija prevođenja s ciljem jačanja apelativnog djelovanja.

Opći smo korpus odlučili iskoristiti i za dijakronijsku analizu, a koristili smo isti model strategija prevođenja kao i u općem dijelu analize općeg korpusa. Dosadašnje analize strategija prevođenja filmskih naslova karakterno su uglavnom bile sinkronijske (Mei, 2010.; Limon, 2012; Šidiškytė i

\footnotetext{
20 No i potpuni prijepisi imena mogu biti manjkavi iz perspektive značenjske ekvivalencije. Limon navodi primjer prijepisa naslova filma Major Payne (Castle, 1995) za slovensko govorno tržište kojim se gubi fonetska igra nastala homofonijom izraza Payne i pain 'bol' (Limon, 2012: 2).

${ }^{21}$ Octopussy je ime lika.

${ }^{22} \mathrm{U}$ korpusu nije bilo hrvatskih primjera za prijepis sa zamjenom.
} 
Tamulaitienė, 2013; Jutronić i Karabatić, 2016; Surdyk i Urban, 2016; Peña-Cervel, 2016). U dijakronijsku perspektivu svoje analize Schubert je uključio filmove iz razdoblja između 1944. i 2002., prikazujući stanje u fazama od deset godina. Schubert zaključuje da su od 1944. do 1963. vodeće strategije prevođenja bile izravni prijevod i transkreacija na ciljni jezik. Međutim, već u vremenu od 1964. do 1973. prijepis postaje najzastupljenija strategija prevođenja te bilježi stalni rast do 2002. kada čini gotovo polovicu prijevoda (47,1 \%). Rast u prijepisima Schubert objašnjava globalizacijskim tendencijama naglašavajući ulogu novih medija, dominacijom Sjedinjenih Američkih Država u svjetskoj popularnoj kulturi te dominacijom engleskog jezika u općem diskursu. Za posljednju fazu Schubert također navodi da je izravni prijevod gotovo jednako zastupljen kao dodavanje (uključujući i slobodne prijevode i prijepise) (Schubert, 2004: 253-257) ${ }^{23}$. Međutim, Schubertov dijakronijski prikaz strategija prevođenja filmskih naslova ne nudi objašnjenja za promjene u zastupljenosti pojedinih strategija u pojedinim fazama. Razne su okolnosti u povijesti kinematografije mogle utjecati na odabir strategija prevođenja filmskih naslova te smo odlučili usporediti rezultate dijakronijske analize s događajima u povijesti kinematografije za koje smo pretpostavili da su mogli utjecati na prevođenje filmskih naslova. $U$ korpusu prevladavaju filmovi američke filmske industrije odnosno Hollywooda, stoga je stavljen poseban naglasak na taj dio povijesti kinematografije. Američka filmska industrija 1920-ih počinje poprimati veliki značaj (Peterlić, 1986: 556-557), a 1927. nastaju prvi zvučni filmovi (Kragić i Gilić, 2003: 505-506). Sljedeći značajan događaj je primjena Haysovog kodeksa od 1934. koji ostaje na snazi sve do 1968. Taj je kodeks bitno odredio sadržaj filmova u Hollywoodu jer je postavio brojna ograničenja te zabranio sve elemente koji bi ,snižavali moralne standarde gledalaca" (Peterlić, 1986: 535). Tijekom Drugog svjetskog rata obustavljena je europska filmska industrija te Hollywood, američki film i engleski jezik stječu još veću prevlast u svjetskoj filmskoj industriji. No krajem 1950-ih nastupa unutarnja kriza Hollywooda zbog čega dolazi do propasti velikih filmskih studija. U vrijeme tog raspada, krajem 1950-ih i početkom 1960-ih, televizija preuzima prevlast pred kinom kao novi filmski medij (ibid.: 557). U Njemačkoj u tom razdoblju također dolazi do smanjenja broja kina (Lorenzo, 2015: 109). Nakon krize slijedi oporavak u 1970-ima i 1980-ima kada započinje tzv. razdoblje novog Hollywooda.

${ }^{23}$ Schubert također primjećuje da izrazom isti i dijakronijski udaljeni originalni naslovi mogu imati različite prijevode. Tako je film The Postman Always Rings Twice 'poštar uvijek zvoni dvaput' (Garnett, 1946) preveden kao Im Netz der Leidenschaften 'u mreži strasti' dok je sljedeća ekranizacija istoimenog romana (Rafelson, 1981) prevedena kao Wenn der Postmann zweimal klingelt 'kad poštar dvaput zazvoni' (Schubert, 2004: 244). 
U ovome su razdoblju veliki filmski studiji zaduženi za distribuciju i svjetski marketing, dok je umjetničko stvaralaštvo prvenstveno u rukama redatelja (Peterlić, 1986: 535). 1980-ih mnogi studiji prelaze na produkciju programa za televiziju, no u 1990-ima počinje prevlast multipleks kina koja se usredotočuju na masovnu projekciju filmova te se povećava broj gledatelja u kinima, kako u SAD-u, tako i u Njemačkoj (Lorenzo, 2015: 110).

Specifični se korpus sastojao od 713 originalnih filmskih naslova te njihovih hrvatskih (680) i njemačkih (692) prijevoda. Za korpusni materijal korišteni su identični izvori, a za odabir naslova koristili smo kriterij popularnosti filma. Svi su originalni naslovi bili na engleskom jeziku. Iz specifičnog su korpusa analizirani samo horori i romantične komedije kako bismo utvrdili vežu li se uz ove žanrove određene strategije prevođenja ili drugi posebni postupci. Konačni korpus sastojao se tako od 78 hrvatskih odnosno 79 njemačkih prijevoda naslova romantičnih komedija te 55 hrvatskih odnosno 56 njemačkih prijevoda naslova horora. Odlučili smo se usredotočiti samo na razdoblje od 2000. do 2016. jer nismo bili sigurni hoće li analiza žanrova pokazati razlike u odnosu na opće stanje. Za analizu specifičnog korpusa korištena je ista metodologija kao i za opći korpus. Razni su autori navodili da naslovi mogu nositi informacije o žanru djela koje naslovljavaju (Nord, 1995; Leonardi, 2011; Limon, 2012; Jutronić i Karabatić, 2016; Surdyk i Urban, 2016). Limon navodi uporabu ključnih riječi (keywords) u naslovu radi ekspliciranja žanra, posebno se osvrčući na horore, trilere, komedije i romantične komedije. U njegovoj analizi prevođenja naslova s engleskog na slovenski jezik najzastupljenije ključne riječi bile su ljubezen 'ljubav', morilec 'ubojica', nor 'lud'odnosno norčija 'ludost' te smrt 'smrt' (Limon, 2012: 4-5). Jutronić i Karabatić kao primjere ključnih riječi u hrvatskim prijevodima navode ljubav, osveta i strah (Jutronić i Karabatić, 2016: 93-94). Iako su se neke od studija koje smo uzeli u obzir izravno ili neizravno bavile analizom prevođenja pojedinih žanrova, samo su Šidiškyte i Tamulaitienè (2013) provele korpusnu analizu strategija prevođenja kako ih shvaćamo u ovome radu. Autorice su na temelje rezultata svoje analize zaključile da žanr ima „specifični utjecaj na odabir strategije prevođenja” Limon navodi da distributeri rjeđe koriste strategiju izravnog prijevoda ako se radi o komediji, akcijskom ili kriminalističkom filmu u odnosu na filmove temeljene na književnim djelima i drame (Limon, 2012: 9). Šidiškytė i Tamulaitienè su ustanovile da je u prevođenju originalnih naslova trilera s engleskog na litavski i ruski jezik najčešći odabir strategije bio izravni prijevod, no u slučaju komedije na vrhu su podjednako zastupljeni i izravni prijevod i transkreacija (Šidiškytè i Tamulaitienè, 2013: 73-75). 


\section{REZULTATI I RASPRAVA}

Tijekom korpusne analize ustanovili smo da za neke primjere ne postoji odgovarajuća strategija prevođenja u našem modelu. I kod hrvatskih i njemačkih prijevoda smo primijetili da neki slobodni prijevodi pokazuju primjenu dvaju tipova modifikacija pa smo u model uveli mješoviti tip slobodnog prijevoda. Nadalje, zabilježili smo i kombinacije prijevoda, izravnog ili slobodnog, i prijepisa koje smo posebno obradili. Najprije ćemo predstaviti rezultate analize općeg korpusa i dijakronijske analize, a zatim ćemo te rezultate usporediti s rezultatima analize naslova romantičnih komedija i horora.

\section{1. Rezultati analize općeg korpusa}

\section{1. 1. Izravni prijevodi}

Većina originalnih filmskih naslova iz općeg korpusa na hrvatski su jezik prevedeni izravno (61,3 \%) (vidi Dijagram 1). Sličan udio zabilježio je i Limon koji u svojoj korpusnoj analizi navodi da je za slovensko govorno tržište 66,8 \% naslova na engleskom jeziku izravno prevedeno. Međutim, Limon u izravne prijevode ubraja i potpune prijepise pa je stvarni udio izravnih prijevoda kako ih mi shvaćamo manji (Limon, 2012: 2). Neki su originalni naslovi iz općeg korpusa izravno prevedeni unatoč očitim poteškoćama. Tako je primjerice naslov filma $V$ for Vendetta (McTeigue, 2005) na hrvatski preveden kao $O$ za osvetu iako je grafem $V$ relevantni vizualni motiv u filmu. Nadalje, primijećeni su izravni prijevodi izrazom identični s prijevodima naslova književnih predložaka prema kojima je napisan scenarij filma, no teško je procijeniti je li se prevodio naslov filma ili je on samo preuzet, npr. War of the Worlds (Spielberg, 2005) > Rat svjetova $^{24}$. Dijakronijska je analiza pokazala da se udio izravnih prijevoda od 1923. do 2016. stupnjevito smanjivao (vidi Dijagram 7). Iako nisu zabilježene nagle promjene u trendu, primijetili smo da nešto veći pad u izravnim prijevodima započinje krajem 1970-ih što možemo povezati s razdobljem novog Hollywooda kada veliku moć u filmskoj industriji dobivaju veliki

\footnotetext{
${ }^{24}$ Scenarij filma temeljen je na romanu H. G. Wellsa The War of the Worlds čiji je naslov na hrvatski preveden kao Rat svjetova.
} 
filmski studiji i distributeri. Međutim, budući da je pad relativno konstantan, pretpostavljamo da je veliki dio 20. stoljeća obilježen stupnjevitom i stalnom komercijalizacijom filma što se odražava u strategijama prevođenja filmskih naslova.

Na njemačkom govornom tržištu izravni su prijevodi druga najzastupljenija strategija prevođenja filmskih naslova s udjelom od 26,6 \% (vidi Dijagram 4). No prijevodi filmskih naslova za njemačko govorno tržište pokazuju ravnomjerniju raspodjelu strategija prevođenja od one za hrvatsko govorno tržište gdje prevladava izravni prijevod. I ovdje smo pronašli neke izravne prijevode koji su izrazom identični s prijevodom književnog predloška za scenarij na istom govornom tržištu, npr. Charlie and the Chocolate Factory 'Charlie i tvornica čokolade' (Burton, 2005) > Charlie und die Schokoladenfabrik ${ }^{25}$. Dijakronijska analiza kao i kod hrvatskih izravnih prijevoda pokazuje stupnjeviti pad udjela izravnih prijevoda (vidi Dijagram 7). Najveći pad zabilježili smo krajem 1970-ih koji povijesno odgovaraju zreloj fazi novog Hollywooda ${ }^{26}$. U razdoblju od 1956. do 1967., neposredno nakon najvećeg zabilježenog pada, primjećuje se blagi i kratkoročni rast u izravnim prijevodima koji vremenski korelira s poslijeratnom krizom u Hollywoodu. Rezultati sugeriraju istaknuti izravni ili neizravni utjecaj američke filmske industrije na odabir strategije prevođenja filmskih naslova.

Nismo primijetili značajne promjene u oblikovanju originalnih naslova zbog kojih bi se namjesto izravnog prijevoda preferirale druge strategije prevođenja ili zbog kojih bi izravni prijevod rjeđe bio povoljno rješenje. $\mathrm{S}$ obzirom na pad udjela izravnih prijevoda i na hrvatskom i na njemačkom govornom tržištu te rast komercijalizacije filmske industrije pretpostavljamo da se ostale strategije prevođenja filmskih naslova u većini slučajeva koriste u službi jačanja apelativnog djelovanja naslova. Nadalje, na temelju razlika u udjelu izvornog prijevoda na dvama govornim tržištima možemo pretpostaviti da su filmski naslovi na njemačkom govornom tržištu bili prije uključeni u komercijalizaciju filma negoli su to bili na hrvatskom govornom tržištu.

\footnotetext{
${ }^{25}$ Prijevod naslova filma ovdje je identičan prijevodu naslova romana Roalda Dahla.

${ }^{26}$ Kokonis navodi da terminologija nije ujednačena te da neki autori za početnu fazu novog Hollywooda koriste termin holivudska renesansa (Hollywood Renaissance). Tako bi holivudska renesansa obuhvaćala razdoblje oporavka nakon poslijeratne krize na prijelazu iz 1960-ih u 1970-e nakon čega bi slijedilo razdoblje novog Hollywooda (Kokonis, 2008: 171).
} 


\section{1. 2. Slobodni prijevodi}

Slobodni su prijevodi nakon izravnih prijevoda i prijepisa treća najzastupljenija strategija prevođenja filmskih naslova za hrvatsko govorno tržište s udjelom od 14,9 \%. Dva najzastupljenija tipa slobodnog prijevoda su slobodni prijevod sa zamjenom $(28,5 \%)$ i s pomakom (27\%). Slijede slobodni prijevodi s dodavanjem (21,9\%), oduzimanjem (14,6\%) te mješoviti tip slobodnog prijevoda ${ }^{27}(8 \%)$ (vidi Dijagram 2).

Slobodni prijevod sa zamjenom najzastupljeniji je tip slobodnog prijevoda, kako na hrvatskom tako i na njemačkom govornom tržištu. Zamjena je nerijetko služila eksplikaciji radnje kao u primjeru Monsters, Inc. 'čudovišta d. o. o.' (Docter i dr., 2001) > Čudovišta iz ormara. Osim toga zamjenjivali su se kulturno specifični pojmovi općenitijim izrazima koji su poznatiji široj publici kao što pokazuje primjer Slumdog Millionaire 'milijunaš iz slama' (Boyle i Tandan, 2008) > Milijunašs ulice.

U $27 \%$ prijevoda naslova na hrvatski došlo je do pomaka, odnosno do mijenjanja morfosintaktičkih struktura naslova. Takve promjene uključuju mijenjanje broja i lica, prevođenje prijedložnog atributa pridjevskim i obrnuto. U hrvatskim se prijevodima pojavljuje promjena perspektive odnosno isticanje druge semantičke uloge, ovdje agensa, promjenom morfosintaktičke strukture. Tako je primjerice Gone with the Wind 'nestali u vjetru' (Fleming i dr., 1939) preveden kao Zameo ih vjetar, a The Silence of the Lambs 'tišina janjadi' (Demme, 1991) kao Kad jaganjci utihnu. U oba je primjera u hrvatskom prijevodu agens istaknut pomakom u nominativ.

Dodavanje je, kao što je Schubert (2004) zaključio, između ostalog bilo u službi isticanja pripadnosti filma serijalu, u 9 od 30 slučajeva. Isticanje serijala uglavnom se postizalo personalizacijom, npr. For Your Eyes Only 28 'samo za tvoje oči' (Glen, 1981) > James Bond 007: Samo za tvoje oči. U tri navrata u prijevod je dodana brojka kao oznaka za nastavak unutar serijala, npr. The Lost World: Jurassic Park 'izgubljeni svijet: jurski park' (Spielberg, 1997) > Jurski park 2: Izgubljeni svijet. Autor prijevoda ovdje se odlučio i za zamjenu mjesta dvaju dijelova naslova, vjerojatno jer se oznaka za serijal na hrvatskom govornom tržištu načelno ne

\footnotetext{
${ }^{27}$ Mješoviti tip slobodnog prijevoda nije pokazao sustavno pojavljujuće osobine.

${ }^{28}$ Film je dio serijala o Jamesu Bondu.
} 
nalazi u podnaslovu. Nekoliko prijevoda pokazuje eksplicitnije izražavanje radnje filma, npr. Airplane! 'avion!' (Abrahams i dr., 1981) > Ima li pilota u avionu.

Kod slobodnih prijevoda s oduzimanjem najčešće se oduzimao podnaslov kao kod naslova Faust: Eine deutsche Volkssage 29 'Faust: njemačka narodna legenda' (Murnau, 1926) > Faust. Zapazili smo i slučajeve u kojima se iz naslova izuzela oznaka za dio serijala Part 'dio' ostavljajući samo rimsku ili arapsku brojku kao oznaku da se radi o dijelu serijala, kao npr. The Godfather: Part III 'kum: dio treći' (Coppola, 1990) > Kum 3.

Dijakronijska je analiza pokazala relativno snažni rast udjela slobodnih prijevoda od kraja 1970ih što vremenski korelira s većim padom udjela izravnih prijevoda (vidi Dijagram 8). Stoga zaključujemo da je razdoblje novog Hollywooda, obilježeno velikim filmskim studijima i svjetskom distribucijom, utjecalo na promjenu trenda $\mathrm{u}$ odabiru strategije prevođenja filmskih naslova. Budući da smo utvrdili da je kod mnogih slobodnih prijevoda bio moguć izravni prijevod, pretpostavljamo da slobodni prijevod kao strategija prevođenja ima prije svega istaknutu apelativnu funkciju, a ne funkciju mirenja razlika između dvaju značenjskih i/ili jezičnih sustava.

Slobodni je prijevod na njemačkom govornom tržištu četvrta najzastupljenija strategija prevođenja s udjelom od 15,8\%. Najzastupljeniji tip slobodnog prijevoda ovdje je slobodni prijevod sa zamjenom (38,2 \%), a slijede slobodni prijevodi s dodavanjem i oduzimanjem (oba tipa $17,4 \%)$, s pomakom $(15,3 \%)$ te mješoviti tip ${ }^{30}(11,8 \%)$ (vidi Dijagram 5 ).

Kao hrvatski slobodni prijevodi sa zamjenom i njemački pokazuju tendenciju eksplikacije radnje, npr. The Poseidon Adventure 'avantura Posejdona' (Neame i Allen, 1972) > Die Höllenfahrt der Poseidon 'paklena vožnja Posejdona' gdje leksem Höllenfahrt 'paklena vožnja' daje naslutiti dio radnje, kao što i sam ženski rod imena Poseidon upućuje na to da se radi o brodu ${ }^{31}$ što iz originalnog naslova nije razvidno. Kulturna prilagodba u njemačkom je rjeđa nego u hrvatskom, npr. Miracle on 34th Street 'čudo u 34. ulici' (Seaton, 1947) > Das Wunder von Manhattan ‘čudo na Manhattanu'. Osim toga, njemački prijevodi pokazuju dijelom veću emotivnu konotaciju od engleskih originala, kao npr. From Here to Eternity 'odavde u vječnost'

\footnotetext{
${ }^{29}$ Faust je lik u filmu.

${ }^{30}$ Mješoviti tip slobodnog prijevoda nije pokazao sustavno pojavljujuće osobine.

${ }^{31}$ Imenice koje označuju brodove su u njemačkom načelno ženskog roda (Helbig i Buscha, 2001: 246).
} 
(Zinnemann, 1953) > Verdammt in alle Ewigkeit 'proklet za cijelu vječnost' te $A$ Night at the Opera 'noć u operi' (Wood i Goulding, 1935) > Skandal in der Oper 'skandal u operi'.

Slobodni prijevodi s dodavanjem nisu pokazali jedinstvenost. Kao što je Schubert (2004) napomenuo, primijetili smo dodavanje atributa s istaknutom emotivnom konotacijom, npr. Airplane! 'avion!' (Abrahams i dr., 1980) > Die unglaubliche Reise in einem verrückten Flugzeug 'nevjerojatno putovanje u ludom avionu'. Nadalje, u pet se navrata naslov personalizirao dodavanjem imena likova, npr. The Martian 'Marsovac' (Scott, 2015) > Der Marsianer - Rettet Mark Watney 'Marsovac - spasite Marka Watneya'. U trima je slučajevima personalizacija bila u službi isticanja pripadnosti filma serijalu o Jamesu Bondu, npr. You Only Live Twice 'živi se samo dvaput' (Gilbert, 1967) > James Bond 007 - Man lebt nur zweimal. Slobodni prijevodi s dodavanjem većinom nisu sadržavali podnaslove.

Oduzimanje je sa 17,6 \% učestalija strategija prevođenja na njemački nego na hrvatski jezik. Potpuno iste pojave kao i u hrvatskim slobodnim prijevodima možemo naći i u njemačkim kraćenje naslova brisanjem podnaslova, npr. Ben-Hur: A Tale of the Christ ${ }^{32}$ 'Ben-Hur: priča o Kristu' (Niblo i dr., 1925) > Ben Hur, te izbacivanje oznake za dio serijala Part, npr. The Godfather: Part III (Coppola, 1990) 'kum: dio treći' > Der Pate 3 'kum 3'.

U 15,3 \% njemačkih prijevoda pojavljuje se pomak kao strategija, i to često pomak broja. Primijetili smo i prijelaz iz množine u jedninu kao u Strangers on a Train 'stranci u vlaku' (Hitchcock, 1951) > Der Fremde im Zug 'stranac u vlaku', ali i obrnuti slučaj kao u Saboteur 'saboter' (Hitchcock, 1942) > Saboteure 'saboteri'. Osim toga mijenjala se i vrsta člana. Tako je u prijevodu naslova The Lady Vanishes 'dama nestaje' (Hitchcock, 1938) određeni član zamijenjen neodređenim: Eine Dame verschwindet '(jedna) dama nestaje'. Postoje i obrnuti primjeri kao kod naslova Scent of a Woman 'miris žene' (Brest, 1992) > Der Duft der Frauen 'miris žena'.

Dijakronijska je analiza pokazala relativno nagli pad udjela slobodnih prijevoda od sredine 1990ih što vremenski korelira s velikim porastom multipleks kina u Njemačkoj, usredotočenih na masovnu publiku (vidi Dijagram 8). Zabilježen je i kratkoročni, no značajni rast udjela slobodnih prijevoda od polovice 1970-ih do kraja 1980-ih koji vremenski korelira s najvećim padom udjela

\footnotetext{
32 Ben-Hur je ime lika.
} 
izravnih prijevoda što sugerira da je slobodni prijevod određeno vrijeme služio kao intensifikator apelativnog djelovanja na mjestu izravnog prijevoda da bi krajem 20. stoljeća, izgleda, i on bio zamijenjem prijepisom.

I hrvatski i njemačkim slobodnim prijevodima zajedničko je da se korsite u različite svrhe: eksplikaciju, personalizaciju, isticanje pripadnosti filma serijalu itd. Slobodni prijevodi s oduzimanjem pokazali su isto ponašanje i na hrvatskom i na njemačkom govornom tržištu koristeći taj tip modifikacije za kraćenje naslova oduzimanjem podnaslova i redundantnih oznaka za pripadnost filma serijalu. Razlike u ponašanju slobodnih prijevoda s pomakom objašnjavamo pripadnošću hrvatskog slavenskim jezicima koji teže aktivnim konstrukcijama dok njemački bolje podnosi pasivne konstrukcije. Poredbena dijakronijska analiza pokazala je da se slobodni prijevod na obama tržištima u određenom razdoblju koristio kao supstitut za izravni prijevod kojim se nije mogao iskoristiti puni apelativni potencijal naslova.

\section{1. 3. Transkreacije}

Udio transkreacije na hrvatskom govornom tržištu je 7 \%. Iako u većini slučajeva transkreacija nije bila obvezna s obzirom na mogućnost izravnog prevođenja naslova, naišli smo i na obvezne transkreacije. Tako je primjerice naslov filma Point Break ${ }^{33}$ (Bigelow, 1991) na hrvatski transkreiran kao Pakleni val. Transkreacije na hrvatski jezik nerijetko eksplicitnije izražavaju sadržaj filma. Tako je naslov filma Now You See Me 'sad me vidiš' (Leterrier, 2013) preveden kao Majstori iluzije sugerirajući da su likovi u filmu iluzionisti ili slično. U jednom se slučaju apelativno djelovanje osnažilo spajanjem dvaju koncepata koji se na hrvatskom govornom tržištu načelno ne povezuju: Mrs. Doubtfire 'gospođa Doubtfire' (Columbus, 1993) > Tatica u suknji. Zabilježili smo i jedan primjer personalizacije: First Blood ${ }^{34}$ (Kotcheff, 1982) > Rambo. Dijakronijska analiza nije pokazala značajne razlike u udjelu transkreacije (vidi Dijagram 11).

Transkreacija je na njemačkom govornom tržištu treća najzastupljenija strategija prevođenja filmskih naslova s 17,9 \%. I transkreacije za njemačko govorno tržište su većinom bile neobvezne, no zamijetili smo i obvezne, npr. Ace in the Hole 'as u rukavu' (Wilder, 1951) > Reporter des Satans 'Sotonin izvjestitelj'. Neki su originalni naslovi s toponimima transkreirani,

\footnotetext{
${ }^{33}$ Engleski izraz point break označava val idealan za daskanje.

${ }^{34}$ Engleski izraz first blood dio je idioma draw first blood koji otprilike znači prvi ozbiljno napasti.
} 
vjerojatno jer prijepisom ne bi bilo moguće prenijeti konotaciju toponima. Tako je naslov filma Fort Apache (Ford, 1948) na njemački jezik transkreiran kao Bis zum letzten Mann 'do posljednjeg čovjeka'. Toponim Fort Apache označava indijanski rezervat u Arizoni pa njegovo smještanje u naslov sugerira da se radi o vesternu dok na njemačkom govornom tržištu vjerojatno ne bi imao takvo djelovanje. Kao što je i Schubert (2004) u svojoj analizi zabilježio, naišli smo na transkreaciju na izvornom jeziku: Taken 'uzeta' (Morel, 2008) > 96 Hours $^{35}$ '96 sati'. Dijakronijska je analiza pokazala veći i kontinuirani pad udjela transkreacija od polovice 1980-ih što vremenski korelira s najvećim padom udjela izravnih prijevoda i kratkoročnom fazom rasta udjela slobodnih prijevoda. S obzirom na kontinuirani pad triju dosad navedenih strategija prevođenja, pretpostavka je da prijepis ima istaknutu ulogu kao strategija prevođenja filmskih naslova, a koja je, kako dijakronijska analiza pokazuje, i dalje u usponu. Nije jasno može li se preferiranje prijepisa na njemačkom govornom tržištu obrazložiti isključivo prestižem engleskog jezika na dotičnom tržištu.

\section{1. 4. Prijepisi}

Prijepis je druga najzastupljenija strategija prevođenja filmskih naslova na hrvatskom govornom tržištu. Većina prijepisa za hrvatsko govorno tržište bili su potpuni prijepisi (90\%), a prisutni su bili i prijepis s oduzimanjem $(8,7 \%)$ te s dodavanjem (1,3\%) (vidi Dijagram 3 ).

Potpuni se prijepis uglavnom koristio kada su se naslovi sastojali isključivo od imena, npr. Shrek (Adamson i Jenson, 2001) > Shrek. Od 135 potpunih prijepisa, samo se 14 (10,4 \%) ne može obrazložiti sadržavanjem imena ili homografijom. Među tih 14 naišli smo i na neke za koje nije jasno kako se mogla ostvariti značenjska ekvivalencija. Tako su se vjerojatno samo prijepisom mogli sačuvati i značenje i aliteracija u naslovu filma La La Land (Chazelle, 2016).

Kod prijepisa s oduzimanjem uglavnom $(61,5 \%)$ se radilo o oduzimanju engleskog određenog člana s početka naslova, vjerojatno jer predstavljaju specifični jezični fenomen koji nije prisutan u hrvatskom jeziku, a koji ovako strukturiran većinom nema istaknutu ulogu u razumijevanju poruke naslova, npr. The Pink Panther 'ružičasta pantera' (Edwards, 1963) > Pink Panther.

Pronašli smo samo dva primjera prijepisa s dodavanjem kod kojih je dodavanje bilo u službi

${ }^{35}$ Naslov filma je na hrvatski jezik preveden kao 96 sati te je tako mogući primjer imitativnog prijevoda. 
isticanja pripadnosti filma serijalu, npr. Octopussy (Glen, 1983) > James Bond: Octopussy. Dijakronijska analiza nije pokazala značajne promjene u udjelu prijepisa za hrvatsko govorno tržište (vidi Dijagram 9).

Za njemačko je govorno tržište prijepis pak najzastupljenija strategija prevođenja filmskih naslova s udjelom od 38,8 \%. Slične je rezultate dobio i Schubert. U njegovoj analizi prijepis je dominantna strategija prevođenja filmskih naslova već u razdoblju od 1964. do 1973. otkad ostaje vodeća strategija (Schubert, 2004: 255-257). Većinu prijepisa čine potpuni prijepisi (68,7 $\%)$, a slijede prijepisi s dodavanjem $(24,8 \%)$, prijepisi s oduzimanjem $(5,1 \%)$ te prijepisi sa zamjenom $^{36}(1,4 \%)$ (vidi Dijagram 6).

Za razliku od hrvatskih potpunih prijepisa njemački su se mogli objasniti sadržavanjem imena ili homografijom u samo 48,9 \% slučajeva. Većinu potpunih prijepisa čine, dakle, naslovi koji su se mogli prevesti drugom strategijom, a da se potpuno ili djelomično ne izgubi značenjska ekvivalencija. Iako se za mnoge potpune prijepise može reći da imaju relativno jednostavan vokabular na stranom jeziku, neki sadrže i stručnu terminologiju poput naslova filma Source Code $^{37}$ 'izvorni kod' (Jones, 2011). Pronašli smo samo jedan naslov filma koji je prijepisom zadržao igru riječi, a da pritom nije jasno kako bi se to ostvarilo nekom drugom strategijom prevođenja: (500) Days of Summer '(500) dana ljeta'/‘(500) dana Summer’ (Webb, 2009) > (500) Days of Summer. Navedeni naslov višeznačnost ostvaruje homonimijom imena Summer i engleskog izraza summer 'ljeto'.

Prijepisi s dodavanjem drugi su najzastupljeniji tip prijepisa za njemačko govorno tržište. Kao što je i Schubert (2004) u svojoj analizi zaključio, dodavanje se u njemačkim prijepisima prije svega odnosilo na dodavanje podnaslova $(90,9 \%)$ koji su od glavnog dijela naslova gotovo uvijek bili odijeljeni crticom $^{38}$. Nerijetko je u podnaslovima radnja filma bila eksplicitnije izražena, npr. Monsieur Verdoux 'gospodin Verdoux' (Chaplin, 1947) > Monsieur Verdoux Der Frauenmörder von Paris 'gospodin Verdoux - pariški ubojica žena'. Nekim se podnaslovima aludira na neka druga djela, moguće kako bi se ostvario efekt sličan efektu serije.

\footnotetext{
36 Prijepisi sa zamjenom nisu pokazali sustavno pojavljujuće osobine.

${ }^{37}$ Izvorni kod je termin iz programiranja.

38 Samo u jednome prijevodu naslova podnaslov nije bio odijeljen crticom, već zarezom: Dumbo (Armstrong, 1941)

> Dumbo, der fliegende Elefant 'Dumbo, leteći slon'. Dumbo je ime lika.
} 
Tako je primjerice naslov filma $Z$ (Gavras, 1969) za njemačko govorno tržište naslovljen kao $Z-$ Anatomie eines politischen Mordes ' $\mathrm{Z}$ - anatomija političkog ubojstva' čime se aludira na film Anatomy of a Murder 'anatomija ubojstva' (Preminger, 1959) koji je na njemački izravno preveden kao Anatomie eines Mordes. U nekim su se podnaslovima nalazile ključne riječi koje su označavale žanr filma. Tako je naslov filma Halloween 'Noć vještica' (Carpenter, 1978) preveden kao Halloween - Die Nacht des Grauens 'Noć vještica - noć strave' čime se sugerira da se radi o hororu dok podnaslov u prijepisu naslova filma Butch Cassidy and the Sundance Kid 'Butch Cassidy i Sundance Kid' (Hill, 1969) upućuje da se radi o kriminalističkom filmu: Butch Cassidy and the Sundance Kid - Zwei Banditen 'Butch Cassidy i Sundance Kid - dva razbojnika'. Dodavanjem u prijepisu mogao se ostvariti i efekt serije, npr. Skyfall ${ }^{39}$ (Mendes, 2012) > James Bond - Skyfall.

Prijepisima s oduzimanjem se kao i na hrvatskom govornom tržištu uglavnom odstranjivao određeni član (72,2 \%), npr. The Nightmare Before Christmas 'noćna mora prije Božića' (Selick, 1993) > Nightmare Before Christmas ${ }^{40}$.

Dijakronijska je analiza pokazala da udio prijepisa na njemačkom govornom tržištu pokazuje stalni rast od kraja 1950-ih i početka 1960-ih, no najveći smo rast zabilježili krajem 1960-ih što vremenski odgovara prijelazu na razdoblje novog Hollywooda te sredinom 1990-ih kada u Njemačkoj započinje prevlast multipleks kina usmjerenih na masovnu publiku. Druga faza najvećeg rasta vremenski korelira $\mathrm{s}$ najvećim padom udjela slobodnih prijevoda koja pak vremenski korelira s već tada prisutnim padom udjela izravnih prijevoda i transkreacija. Stoga možemo zaključiti da prijepisi na njemačkom govornom tržištu imaju najveći potencijal za apelativno djelovanje. Rezultati analize ukazuju na trend zamjenjivanja ostalih strategija prevođenja prijepisom. Razni su autori prijepise originalnih engleskih filmskih naslova objašnjavali prestižem engleskog jezika na ciljnom tržištu (Schubert, 2004; Jutronić i Karabatić, 2016; Surdyk i Urban, 2016).

Dok se na hrvatskom govornom tržištu kod prijepisa uglavnom radi o potpunim prijepisima imena, njemački prijepisi pokazuju veću raznolikost uporabe te strategije. Budući da

\footnotetext{
${ }^{39}$ Skyfall je toponim.

40 Takvu smo situaciju zabilježili i kod jednog francuskog originalnog naslova: L'Atalante (Vigo, 1934) > Atalante. Atalante je ime broda koji se pojavljuje u filmu.
} 
pretpostavljamo da prijepisi engleskih originalnih naslova imaju veće apelativno djelovanje zahvaljujući prestižu engleskog jezika na ciljnom tržištu, zaključujemo, kao i kod izravnih prijevoda, da se na hrvatskom govornom tržištu ne posvećuje tolika pažnja apelativnom djelovanju naslova kao što se posvećuje na njemačkom govornom tržištu ${ }^{41}$. Međutim, rezultati analize ipak pokazuju da iz perspektive hrvatskog govornog tržišta hrvatski prijevodi naslova često imaju jače apelativno djelovanje od originala. Nadalje, hrvatski se i njemački prijepisi uvelike razlikuju u udjelu prijepisa s dodavanjem, vjerojatno jer na hrvatskom govornom tržištu, kao što smo analizom utvrdili, nema tendencije prijepisa originalnih naslova koji se mogu izravno prevesti, a s čime je korelirana tendencija dodavanja podnaslova. Henning Bochert je pretpostavio da se na njemačkom tržištu često dodaju podnaslovi kako bi se uspostavila ravnoteža između velikog utjecaja engleskog jezika u Njemačkoj i statusa njemačkog kao službenog i nacionalnog jezika.

\section{1. 5. Kombinacije prijevoda i prijepisa}

Svi naslovi filmova koji su za hrvatsko govorno tržište prevedeni kombinacijom prijevoda i prijepisa pripadali su filmovima koji su dio serijala, npr. Rogue One: A Star Wars Story 'odmetnik jedan: priča iz Ratova zvijezda' (Edwards, 2016) > Rogue One: Priča iz Ratova zvijezda. Pretpostavljamo da je pojava ove strategije prevođenja povezana s rastom u produkciji filmskih serijala. Schubert navodi da se u njemačkim prijevodima nerijetko nastoji istaknuti pripadnost filma serijalu (Schubert, 2004: 245). Moguće je da se prijepisom dijela koji upućuje na pripadnost filma serijalu nastoji ojačati apelativno djelovanje naslova smještajući ga u već poznati kontekst što je Schubert povezao s efektom serije (ibid.: 247).

I na njemačkom su govornom tržištu kombinacije prijevoda i prijepisa isključivo vezane uz filmske serijale, npr. Pirates of the Caribbean: At World's End 'pirati s Kariba: na kraju svijeta' (Verbinski, 2007) > Pirates of the Caribbean - Am Ende der Welt. Zaključujemo da se kod kombinacije prijepisa i prijevoda radi o jačanju apelativnog djelovanja naslova zahvaljujući efektu serije i prestižu engleskog jezika na ciljnom tržištu.

\footnotetext{
${ }^{41}$ Možemo pretpostaviti da na hrvatskom govornom tržištu istaknutiju ulogu u privlačenju potrošača imaju drugi prateći elementi filma.
} 


\section{2. Rezultati analize specifičnog korpusa}

Iz analize specifičnog korpusa $\mathrm{u}$ ovome dijelu rada bit će prikazani samo oni rezultati koji odstupaju od rezultata dobivenih analizom općeg korpusa. Najprije ćemo se osvrnuti na naslove romantičnih komedija, a zatim horora.

\section{2. 1. Naslovi romantičnih komedija}

Analiza strategija prevođenja naslova romantičnih komedija na hrvatski jezik pokazala je veća odstupanja od rezultata analize općeg korpusa samo kod transkreacije ${ }^{42}$ (vidi Dijagram 12). Transkreacija je među prijevodima naslova romantičnih komedija na hrvatski s $54,2 \%$ najzastupljenija strategija prevođenja što je značajna razlika u odnosu na opći korpus gdje je bila zastupljena sa samo $7 \%$. Česti su prijevodi koji koriste emotivno konotirane riječi kao kod naslova The Other Woman 'druga žena' (Cassavetes, 2014) koji je preveden kao Osveta na visokim petama. Osim toga u prijevodima su zastupljene i igre riječi ili poslovice kao u You, Me and Dupree 'ti, ja i Dupree' (Russo i Russo, 2006) > Svakog gosta tri dana dosta, ali i oni koji ekspliciraju radnju, primjerice 27 Dresses '27 haljina' (Fletcher, 2008) > Zauvijek djeveruša, nikad nevjesta. Ipak ne postoji nijedna pojava u prijevodima koja bi se pojavljivala dovoljno često i sustavno da bi se moglo govoriti o obrascu te stoga nije jasno zašto se kod naslova romantičnih komedija preferira upravo transkreacija.

Transkreacija je i u prijevodima naslova romantičnih komedija na njemački najzastupljenija s 55,4 \% (vidi Dijagram 13). I ovdje se radi o značajnoj razlici u odnosu na opći korpus gdje je transkreacija bila zastupljena sa 17,9 \%. Među njima se može uočiti veliki udio naslova u kojima je eksplicirana radnja $(38,1 \%)$. Osim toga česte su verbalizacije ili barem uvođenje glagola u infinitivu kao primjerice Better Living Through Chemistry 'bolji život kroz kemiju' (Moore i Posamentier, 2014) > Hauptsache, die Chemie stimmt 'glavno da kemija funkcionira'. Ako se tome još pribroje naslovi u kojima su korišteni pridjevi u komparativu, pitanja i konstrukcije koje doduše ne sadržavaju glagol, ali ga impliciraju, dobije se veliki udio naslova koji pokazuju težnju ka dinamici $(45,2 \%)$. Kognitivnolingvistički je zanimljiv primjer The Five-Year Engagement

\footnotetext{
42 Ustanovili smo da nije bilo prijepisa naslova romantičnih komedija, no u korpusu je bio prisutan samo jedan naslov koji je bio sastavljen isključivo od imena. Radi se o naslovu filma Hope Springs (Frankel, 2012) koji sadrži toponim Hope Springs, ali kojim se postiže referencija na poslovicu hope springs eternal 'nada umire posljednja'. ${ }^{43}$ Posljedično je manji udio izravnih prijevoda $(27,1 \%)$.
} 
'petogodišnje zaruke' (Stoller, 2012) > Fast verheiratet 'gotovo zaručeni' jer original predočuje statičnu sliku vremenskog razdoblja od pet godina određenog stanja (zaručništva) kao zaokružene cjeline, dok prijevod implicira put prema nekom cilju (vjenčanju) te tako stvara dinamičnu sliku.

Transkreacija je i na njemačkom govornom tržištu najzastupljenija strategija prevođenja $s$ udjelom od 55,4\% što odstupa od rezultata analize općeg korpusa gdje je transkracija bila zastupljena s 17,9 \%. Posljedično je manji udio prijepisa (17,9 \%) i izravnog prijevoda (7,1\%). Njemački prijevodi pokazuju veću ujednačenost među transkreacijama - većina ih teži eksplikaciji i većoj dinamici, dok među hrvatskim prijevodima nema očitog obrasca. Zanimljivo je također da je naslov filma My Life in Ruins 'moj život u ruševinama' (Petrie, 2009) na obama tržištima transkreiran uz aluziju na prijevode naslova filma My Big Fat Greek Wedding 'moje veliko, debelo grčko vjenčanje' (Zwick, 2002) koji je na hrvatski jezik preveden kao Moje grčko vjenčanje, a na njemački kao My Big Fat Greek Wedding - Hochzeit auf griechisch 'moje veliko, debelo grčko vjenčanje - vjenčanje na grčki način'. Tako se naslov filma My Life in Ruins na hrvatski transkreirao kao Moja grčka avantura, a za njemačko govorno tržište kao My Big Fat Greek Summer 'moje veliko, debelo grčko ljeto'. Poveznica između dvaju filmova je glavna glumica, a djelomično i sudbine glavnih junakinja koje glumica prikazuje.

Naslovi romantičnih komedija su i za hrvatsko i njemačko govorno tržište uglavnom bili transkreirani što odudara od rezultata analize općeg korpusa. Dok se kod njemačkih transkreacija nerijetko postižu eksplicitnije izražavanje o radnji filma i veća dinamika, kod hrvatskih transkreacija nije jasno što uvjetuje njihov odabir. Šidiškytė i Tamulaitienè su u svojoj analizi strategija prevođenja engleskih naslova komedija na litavski i ruski također primijetile veliki udio transkreacija objašnjavajući to težnjom za jačanjem apelativnog djelovanja naslova (Šidiškyte i Tamulaitienè, 2013: 73). Možemo zaključiti da i žanr filma ima istankut utjecaj na odabir strategije prevođenja naslova.

\section{2. 2. Naslovi horora}

Analiza strategija prevođenja naslova horora na hrvatski jezik nije pokazala veća odstupanja od rezultata analize općeg korpusa (vidi Dijagram 14). Međutim, kao što su Jutronić i Karabatić (2016) također primijetile, uočili smo ključne riječi u funkciji isticanja žanra. Tako je primjerice 
naslov filma The Cave 'špilja' (Hunt, 2005) preveden kao Špilja straha. Ostali primjeri ključnih riječi uključuju uklet, tajna, misteriozan, strava i mrak, a svaka je bila zastupljena jedanput osim strah koji smo uočili kod dva prijevoda.

Rezultati analize njemačkih prijevoda naslova horora pokazuju veliku dominaciju prijepisa $\mathrm{s}$ udjelom od 83,5 \% (vidi Dijagram 15) dok je udio u općem korpusu iznosio 38,8 \%. Rast udjela prijepisa može se objasniti rastom udjela prijepisa s dodavanjem koji čine 57,6 \% (vidi Dijagram 16) prijepisa u odnosu na opći korpus gdje su činili $24,8 \%$ prijepisa. Manji udio potpunih prijepisa može se objasniti manjim udjelom naslova koji sadrže isključivo imena. Gotovo svi prijepisi s dodavanjem nastali su dodavanjem podnaslova, a u 78,9 \% slučajeva u podnaslovu je bila izražena ključna riječ za identificiranje žanra, npr. Captivity 'zatočeništvo' (Joffé, 2007) > Captivity - Tödliches Spiel 'zatočeništvo - smrtonosna igra'. Neki su naslovi sadržavali dvije ključne riječi. Ključne riječi uključuju Tod 'smrt', tödlich 'smrtonosan', tot 'mrtav' te töten 'ubiti' (7), zatim Grauen 'strava' (4), Hölle 'pakao' (4), dunkel 'taman' (2), das Böse 'zlo' (2), Angst 'strah' (2), Panik 'panika' (1), sterben 'umrijeti' (1), Geheimnis 'tajna' (1), schwarz 'crn' (1), blutig 'krvav' (1), Schrecken 'užas' (1), Monster ‘čudovište' (1) te Teufel 'vrag' (1).

Rezultati analize strategija prevođenja naslova horora također sugeriraju utjecaj žanra na odabir stragije prevođenja, no samo na njemačkom govornom tržištu. Moguće da su se naslovi na hrvatskom govornom tržištu izravno preveli jer već originalni naslovi horora imaju dovoljno elemenata kojima se može identificirati žanr. No onda nije jasno zašto se na njemačkom govornom tržištu nastoji dodatni ojačati metatekstualna funkcija. 


\section{ZAKLJUČAK}

Kako bismo analizirali strategije prevođenja filmskih naslova, izradili smo dva korpusa, opći i specifični, sastavljena od originalnih filmskih naslova, većinom na engleskom jeziku, i njihovih hrvatskih i njemačkih prijevoda. Opći se korpus sastojao od 917 hrvatskih i 914 njemačkih prijevoda filmskih naslova te je analiziran prema modificiranom Schubertovom (2004) modelu strategija prevođenja. Opći smo korpus analizirali i dijakronijski. Specifični se korpus sastojao od 78 hrvatskih odnosno 79 njemačkih prijevoda naslova romantičnih komedija te 55 hrvatskih odnosno 56 njemačkih prijevoda naslova horora.

Potvrdili smo većinu hipoteza. Ustanovili smo da se odabir strategija prevođnja filmskih naslova razlikuje na hrvatskom i njemačkom govornom tržištu. Dok je na hrvatskome dominantna strategija prevođenja izravni prijevod, na njemačkom se govornom tržištu najčešće koristila strategija prijepisa. Pritom većina prijepisa na hrvatskom govornom tržištu predstavljaju potpuni prijepisi naslova s imenima dok se prijepis na njemačkom govornom tržištu većinom koristi za jačanje apelativnog djelovanja naslova zahvaljujući prestižu engleskog jezika u njemačkoj govornoj zajednici. Razlike u odabiru strategije prevođenja filmskih naslova na dvama tržištima također sugeriraju različit stupanj komercijalizacije filmskog naslova.

Dijakronijska je analiza potvrdila da su se od 1923. do 2016. mijenjali trendovi korištenja pojedinih strategija prevođenja. Zajedničko i hrvatskom i njemačkom govornom tržištu jest stupnjeviti i kontinuirani pad udjela izravnog prijevoda koji je na hrvatskom govornom tržištu nadoknađen rastom udjela slobodnog prijevoda, a na njemačkom prijepisa. Njemačko govorno tržište tako pokazuje dijakronijski pad udjela svih strategija prevođenja filmskih naslova u korist prijepisa. Promjene u trendu mogu se objasniti događajima u povijesti kinematografije, a glavnom se povijesnom točkom pokazao prijelaz na razdoblje novog Hollywooda dok je za njemačko govorno područje također važna sredina 1990-ih kada u Njemačkoj raste broj multipleks kina. Međutim, unatoč našim očekivanjima nismo zabilježili rast prijepisa na hrvatskom govornom tržištu.

Rezultati analize općeg korpusa i njegove dijakronijske analize upućuju da sve strategije prevođenja filmskih naslova osim izravnog prijevoda načelno služe jačanju apelativnog 
djelovanja naslova. To smo naročito pokušali dokazati dijakronijskom analizom koja je za njemačko govorno tržište najprije pokazala prodor slobodnog prijevoda i prijepisa kao strategija S najvećim apelativnim potencijalom da bi sredinom 1990-ih sve strategije prevođenja osim prijepisa bile u padu. Takvi rezultati sugeriraju da prijepis na njemačkom govornom tržištu ima najveći apelativni potencijal. To se jednim dijelom može objasniti prestižem engleskog jezika u njemačkoj govornoj zajednici, no, kako je napomenuo i Bochert, moguće je da se radi o uspostavljanju ravnoteže između engleskog kao svjetskog jezika i njemačkog kao nacionalnog jezika. Tome u prilog idu i rezultati analize slobodnih prijevoda kod kojih nije bilo mnogo podnaslova za razliku od prijepisa gdje je prijepis s dodavanjem podnaslova najzastupljeniji tip prijepisa s modifikacijom.

Naposljetku smo analizom specifičnog korpusa ustanovili da žanr ima istaknuti utjecaj na odabir strategije prevođenja filmskog naslova. Ustanovili smo da se i na hrvatskome i na njemačkom govornom tržištu naslovi romantičnih komedija najčešće transkreiraju dok se ta strategija prevođenja u općem korpusu nije pokazala toliko plodnom. Analiza naslova nije pokazala razlike za hrvatsko govorno tržište u odnosu na opći korpus, ali je na njemačkom govornom tržištu primijećen veći udio prijepisa s dodavanjem u odnosu na opći korpus. 


\section{DIJAGRAMI}

Prijevodi na hrvatski jezik

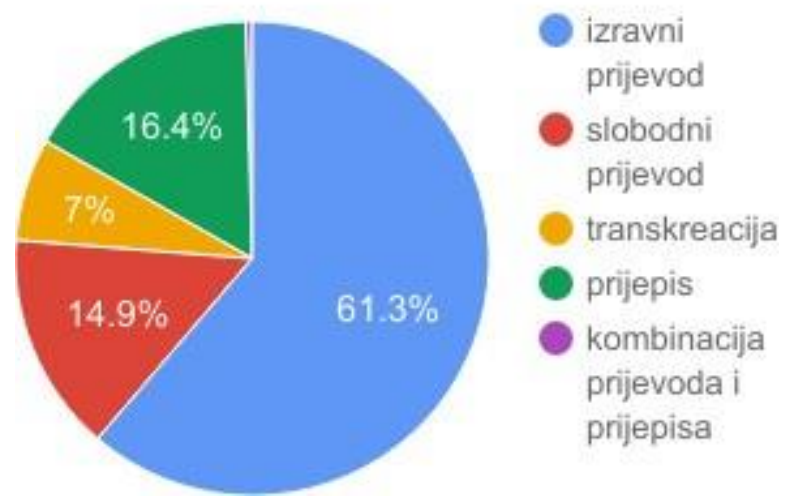

Dijagram 1 Prijevodi na hrvatski jezik, opći korpus

Slobodni prijevodi na hrvatski jezik

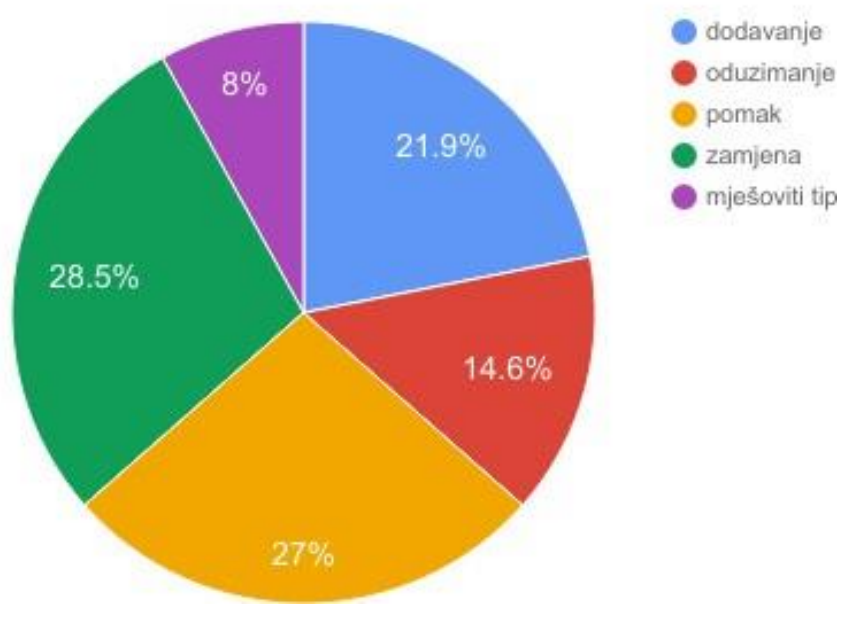

Dijagram 2 Slobodni prijevodi na hrvatski jezik, opći korpus 
Prijepisi za hrvatsko govorno tržište

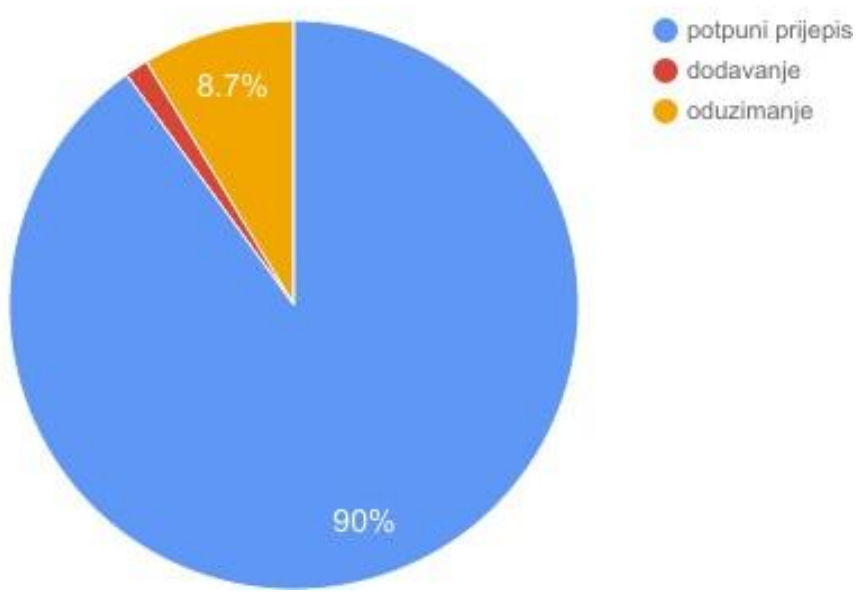

Dijagram 3 Prijepisi za hrvatsko govorno tržište, opći korpus

Prijevodi na njemački jezik

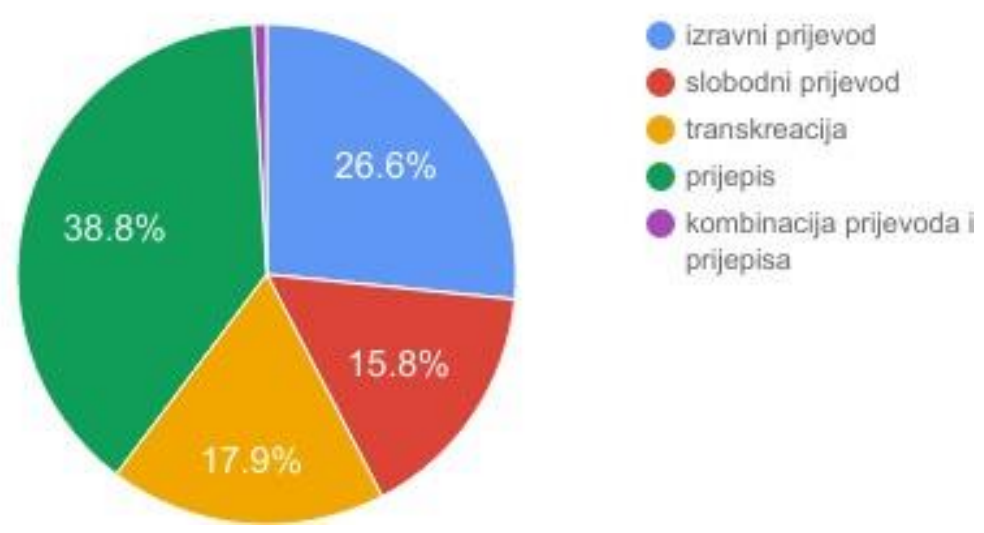

Dijagram 4 Prijevodi na njemački jezik, opći korpus 
Slobodni prijevodi na njemački jezik

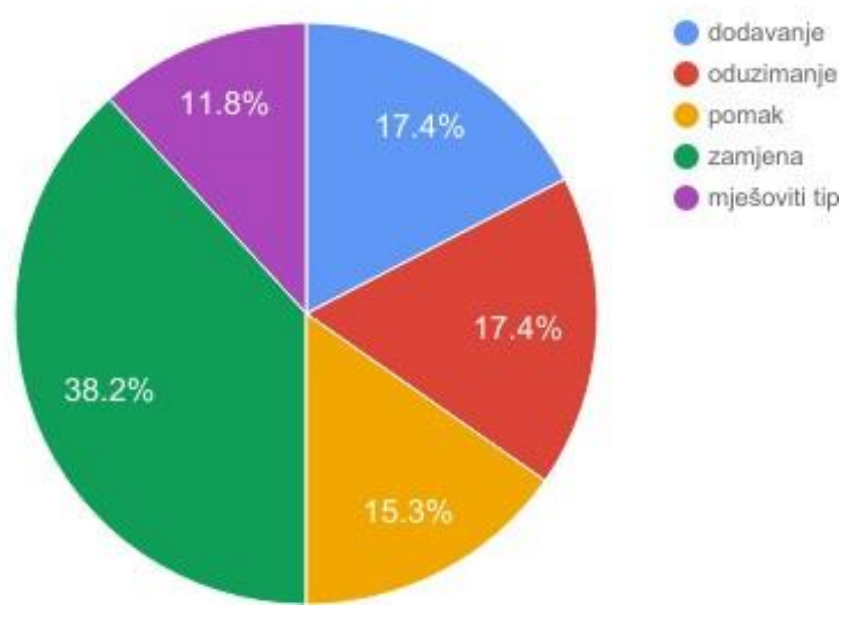

Dijagram 5 Slobodni prijevodi na njemački jezik, opći korpus

Prijepisi za njemačko govorno tržište

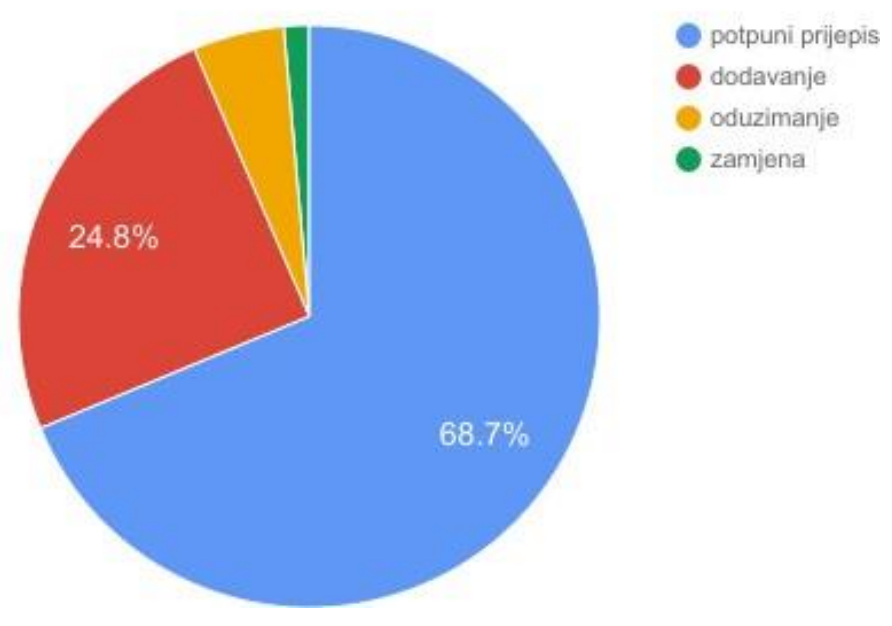

Dijagram 6 Prijepisi za njemačko govorno tržište, opći korpus 


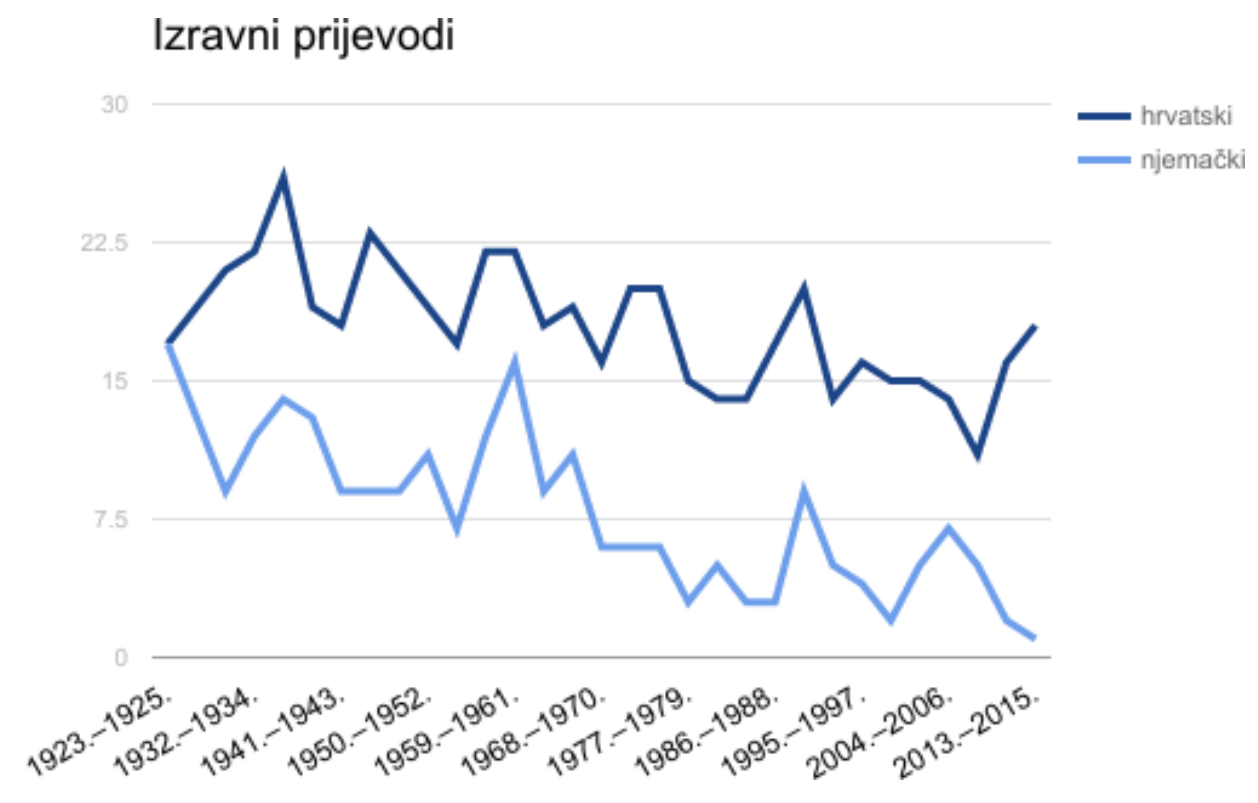

Dijagram 7 Dijakronijski prikaz izravnih prijevoda na hrvatski i njemački jezik

Slobodni prijevodi, dijakronijski prikaz

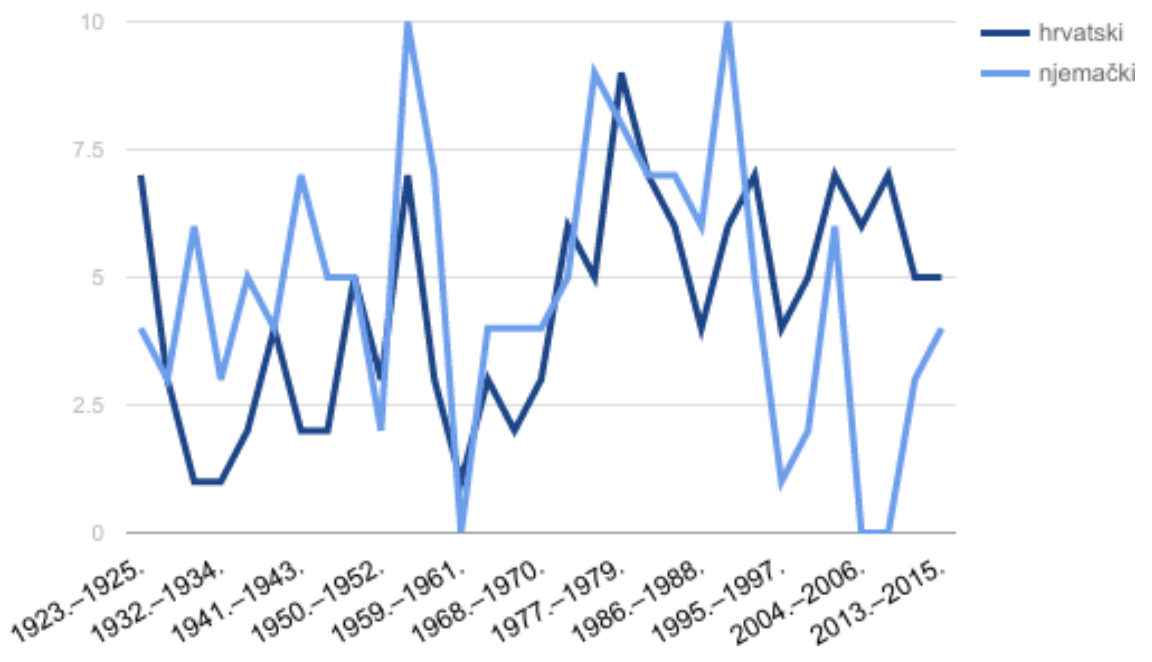

Dijagram 8 Dijakronijski prikaz slobodnih prijevoda na hrvatski i njemački jezik 


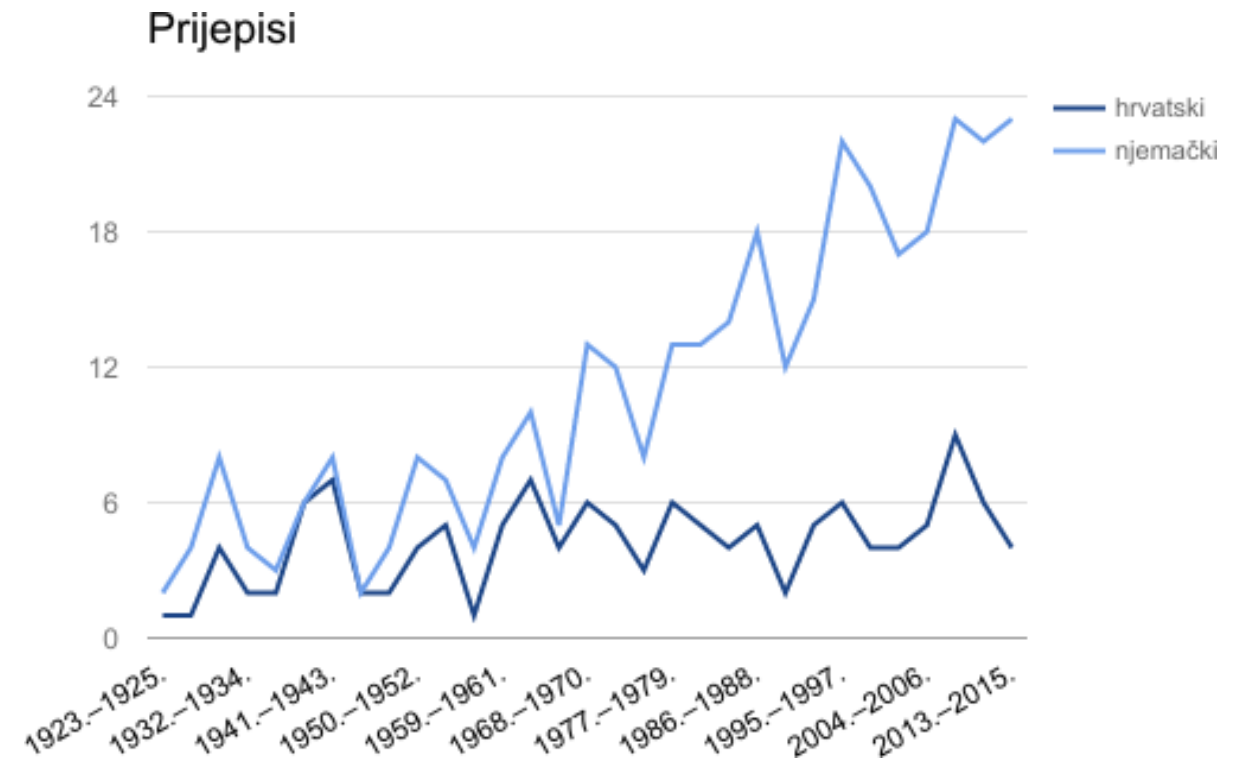

Dijagram 9 Dijakronijski prikaz prijepisa na hrvatski i njemački jezik

\section{Prijepisi s dodavanjem}

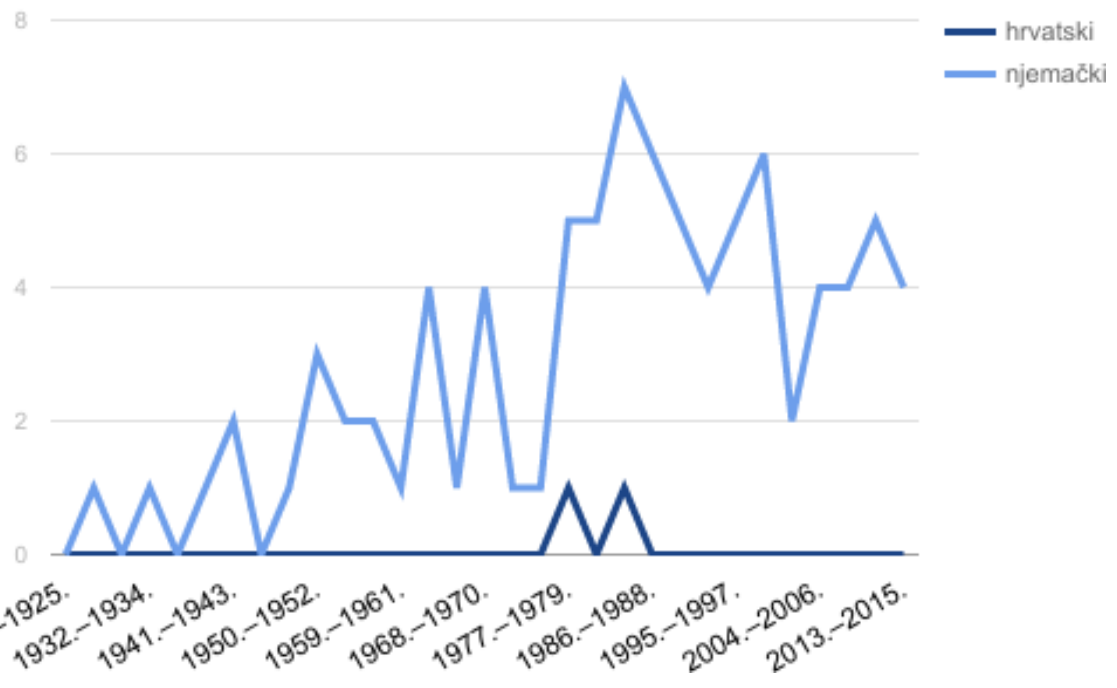

Dijagram 10 Dijakronijski prikaz prijepisa s dodavanjem na hrvatski i njemački jezik 


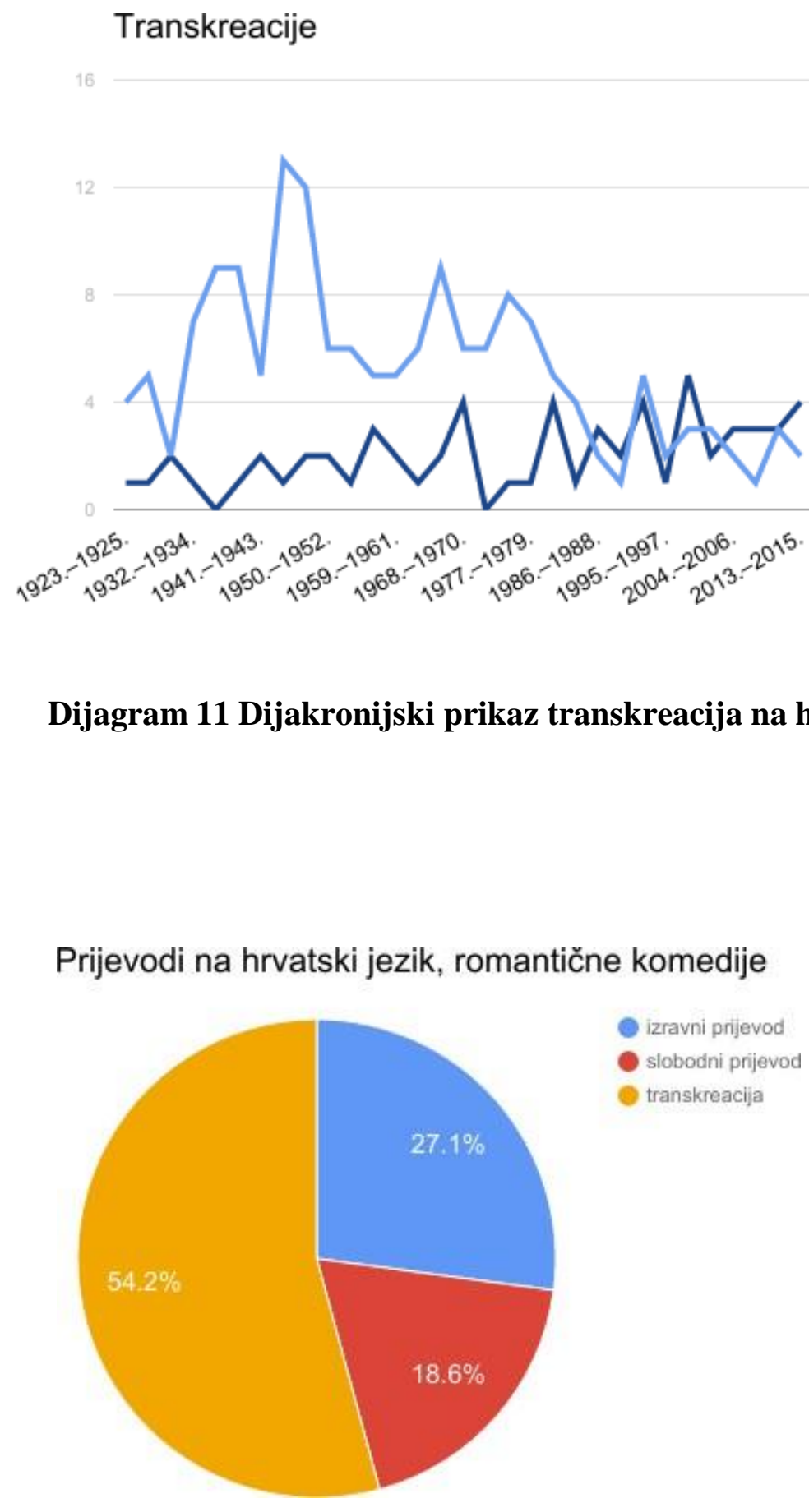

Dijagram 12 Prijevodi naslova romantičnih komedija na hrvatski jezik 
Prijevodi na njemački jezik, romantične komedije

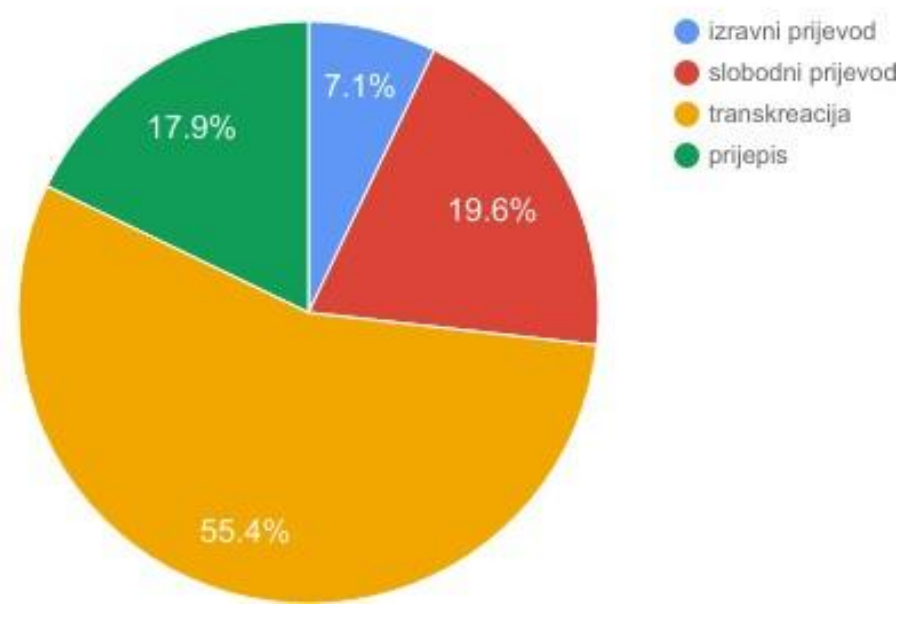

Dijagram 13 Prijevodi naslova romantičnih komedija na njemački jezik

Prijevodi na hrvatski jezik, horori

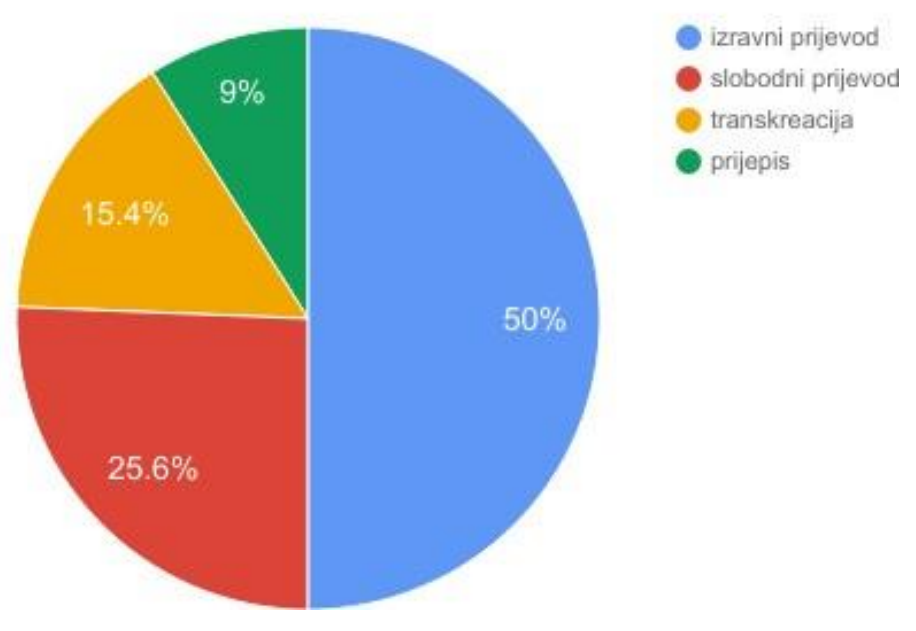

Dijagram 14 Prijevodi naslova horora na hrvatski jezik 
Prijevodi na njemački jezik, horori

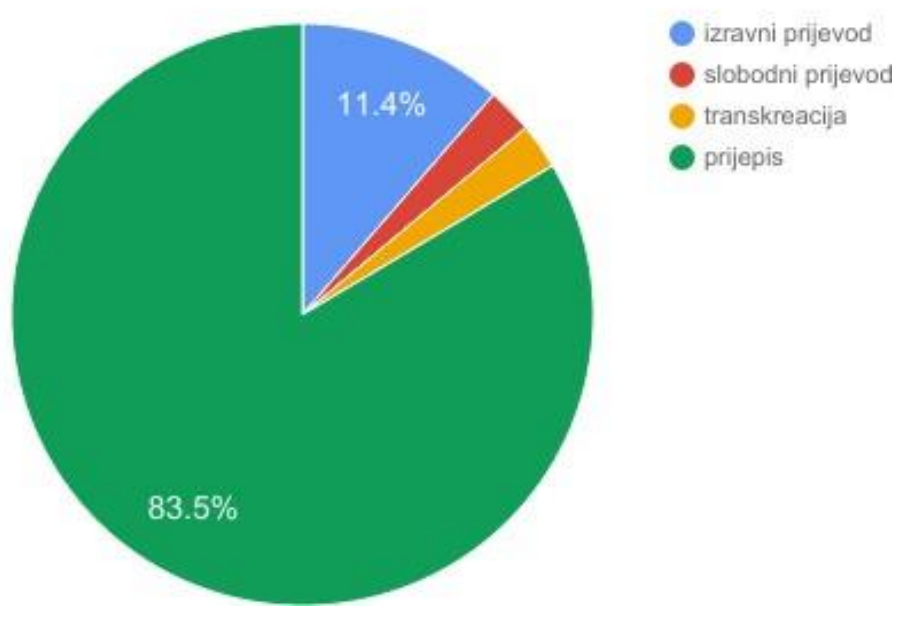

Dijagram 15 Prijevodi naslova horora na njemački jezik

Prijepisi za njemačko govorno tržište, horori

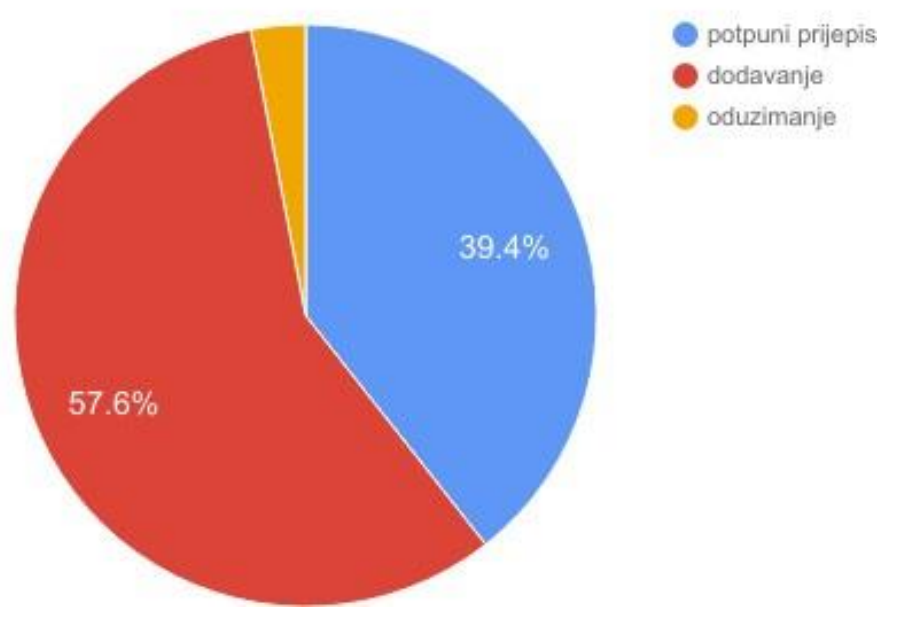

Dijagram 16 Prijepisi naslova horora za njemačko govorno tržište 


\section{ZAHVALE}

U prvom redu zahvaljujemo mentoru dr. sc. Velimiru Piškorcu na poticaju i potpori koju nam je pružio tijekom istraživanja i pisanja ovog znanstvenog rada.

Želimo zahvaliti i višoj lektorici Inji Skender Libhard s Odsjeka za germanistiku na podršci i pomoći pri odabiru teorijskih djela za rad i ostvarivanju kontakta s Hrvatskom radiotelevizijom.

Posebnu zahvalnost želimo iskazati voditeljici Službe za prijevode HRT-a Branimiri Borčić Nemec za sve informacije o radu prevoditelja na Hrvatskoj radioteleviziji.

Zahvaljujemo Hennningu Bochertu iz Bochert Translations na informacijama o radu njemačkih prevoditelja i prijevodnim strategijama raširenim na njemačkom tržištu.

Također zahvaljujemo Timmu Oberwellandu iz TOBIS Film GmbH na mogućnosti uvida u rad distributerskih tvrtki na njemačkom govornom području.

Želimo zahvaliti i ugovornoj lektorici DAAD-a Ivani Bašić s Odsjeka za germanistiku na pomoći pri pronalasku literature za teorijski dio rada.

Zahvaljujemo i redovitoj profesorici dr. sc. Idi Raffaelli s Odsjeka za lingvistiku i redovitoj profesorici dr. sc. Tatjani Jukić Gregurić s Odsjeka za anglistiku za njihove savjete.

Na kraju želimo zahvaliti i svojim kolegama s Filozofskog fakulteta koji su nam pomogli redom sa švedskim, poljskim, japanskim i ruskim jezikom: Ivani Hanžek, Martinu Ježoviti, Mariji Juratek i Mariji Matić. 


\section{POPIS LITERATURE}

1. Baker, M. (ur.) (1998). Routledge Encyclopedia of Translation Studies. London / New York: Routledge.

2. Berdis, V. (2013). English film titles and their Czech equivalents. Neobjavljeni završni rad. Masarykovo sveučilište, Brno.

3. Böhnke, A. (2007). Paratexte des Films. Über die Grenzen des filmischen Universums. Bielefeld: transcript.

4. Bouchehri, R. (2008). Filmtitel im interkulturellen Transfer. Berlin: Frank \& Timme.

5. Bühler, K. (1934). Sprachtheorie. Jena: Verlag von Gustav Fischer.

6. Genette, G. (1989). Paratexte. Das Buch vom Beiwerk des Buches. Frankfurt na Majni / New York: Campus Verlag.

7. Helbig, G., Buscha, J. (2001). Deutsche Grammatik: ein Handbuch für den Ausländerunterricht. Berlin: Langenscheidt.

8. House, J. (1996). Contrastive discourse analysis and misunderstanding: The case of German and English. U: Hellinger, M., Ammon, U. (ur.). Contrastive Sociolinguistics. Berlin: De Gruyter Mouton, 345-361.

9. Iannelli, E. C. (2015). Riflessione sulla traduzione dei titoli dei film. Milano: S. I. Editore. 10. Jojić, Lj. (2015). Veliki rječnik hrvatskoga standardnog jezika. Zagreb: Školska knjiga.

11. Jutronić, D., Karabatić, T. (2016). Translation of English feature films titles in Croatian. Zbornik radova Filozofskog fakulteta u Splitu, 8, 85-103.

12. Katnić-Bakaršić, M. (1999). Lingvistička stilistika. Budimpešta: Open Society Institute.

13. Kokonis, M. (2008). Hollywood's Major Crisis and the American Film "Renaissance".

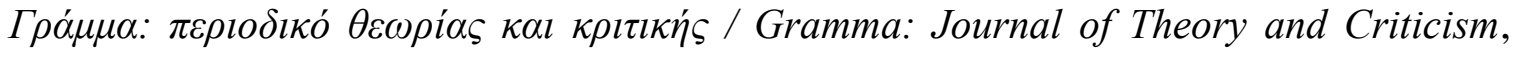
16(1), 169-206.

14. Kragić, B., Gilić, N. (ur.) (2003). Filmski leksikon. A-Ž. Zagreb: Leksikografski zavod Miroslav Krleža.

15. Leonardi, V. (2011). Translating film titles: linguistic skills, cultural awareness or marketing strategies?. Language, Communication and Social Environment, 9, 180-201.

16. Limon, D. (2012). Film titles and cultural transfer. Cultus: the Intercultural Journal of 
Mediation and Communication, 5, 189-208.

17. Lorenzo, G. di (ur.) (2015). Film: Geschichte des Films in Deutschland. Hamburg: Zeitverlag Gerd Bucerius GmbG i Co. KG.

18. Mei, Z. (2010). On the Translation Strategies of English Film Title from the Perspective of Skopos Theory. Journal of Language Teaching and Research, 1(1), 66-68.

19. Negro Alousque, I. (2015). The role of cognitive operations in the translation of film titles. Procedia - Social and Behavioral Sciences, 212, 237-241.

20. Nord, C. (1995). Text-Functions in Translation: Titles and Headings as a Case in Point. Target, 7(2), 261-284.

21. Pavlović, N. (2015). Uvod u teorije prevođenja. Zagreb: Leykam international.

22. Peterlić, A. (ur.) (1986). Filmska enciklopedija. 1, A-K. Zagreb: Jugoslavenski leksikografski zavod Miroslav Krleža.

23. Raffaelli, I. (2009). Značenje kroz vrijeme. Poglavlja iz dijakronijske semantike. Zagreb: Disput.

24. Ravlić, S. (2006). Hrvatska enciklopedija. 8, O-Pre. Zagreb: Leksikografski zavod Miroslav Krleža.

25. Rojo, A., Ibarretxe-Antuñano, I. (ur.) (2013). Cognitive Linguistics and Translation. Advances in Some Theoretical Models and Applications. Berlin: De Gruyter Mouton.

26. Schubert, C. (2004). Die Appelwirkung englischer Filmtitel und ihrer deutschen Neutitel: Techniken interkulturellen Transfers. AAA - Arbeiten aus Anglistik und Amerikanistik, 29(2), 239-259.

27. Stanojević, M. (2013). Konceptualna metafora: temeljni pojmovi, teorijski pristupi $i$ metode. Zagreb: Srednja Europa.

28. Surdyk, A., Urban, A., (2016). Mistranslations of Film Titles: Between Fidelity and Advertising. Glottodidactica, 43(1), 153-170.

29. Šidiškytė, D., Tamulaitienė, D. (2013). The Contrastive Analysis of the Translation of English Film Titles into Lithuanian and Russian. Kalbu studijos / Studies about Languages, 22, 71-77. 


\section{SAŽETAK}

Petar Gabrić, Iva Brajković, Letizia Licchetta, Juraj Bezuh, Dorotea Kelčec Ključarić

\section{ANALIZA STRATEGIJA PREVOĐENJA FILMSKIH NASLOVA NA HRVATSKI I NJEMAČKI JEZIK}

Razni su autori predložili istaknutu ulogu filmskih naslova u razumijevanju filma u cjelini pri čemu prije svega naglašavaju apelativnu funkciju naslova koja za cilj ima navesti adresata poruke na konzumiranje proizvoda. Budući da se uz tekst filma kao djela za ciljno tržište načelno prevodi i naslov, odlučili smo provesti analizu strategija prevođenja filmskih naslova na hrvatski i njemački jezik. Izradili smo dva korpusa sastavljena od originalnih filmskih naslova (uglavnom na engleskom jeziku) i njihovih prijevoda na hrvatski i njemački jezik. U prvome korpusu analizirani su prijevodi 935 filmskih naslova koji su stajali za filmove praizvedene između 1923. i 2016. Prijevodi su kategorizirani prema korištenim strategijama prevođenja. Model strategija prevođenja izrađen je s obzirom na manipulacije značenjskim i/ili specifičnim jezičnim strukturama iz originala. Prvi smo korpus i dijakronijski analizirali kako bismo ustanovili eventualne promjene trendova i pokušali objasniti te promjene. Drugi je korpus korišten za analizu prijevoda naslova horora i romantičnih komedija kako bismo provjerili ima li žanr utjecaj na odabir strategije prevođenja naslova. Iz drugog smo korpusa analizirali prijevode 80-ak originalnih naslova horora i 60-ak originalnih naslova romantičnih komedija prema istome principu kao i prijevode iz prvog korpusa. Rezultati naše analize sugeriraju razlike u odabiru strategija prevođenja za hrvatsko i njemačko govorno tržište. Dok su naslovi na hrvatski jezik uglavnom izravno prevedeni, najčešća strategija prevođenja za njemačko govorno tržište je prijepis originalnog naslova, a često je i dodavanje struktura koje nisu prisutne u originalu. Analiza naslova horora i romantičnih komedija upućuje da i žanr filma utječe na odabir strategije prevođenja, s razlikama između dvaju tržišta.

KLJUČNE RIJEČI: filmski naslovi, strategije prevođenja, apelativna jezična funkcija, hrvatski jezik, njemački jezik 


\section{SUMMARY}

Petar Gabrić, Iva Brajković, Letizia Licchetta, Juraj Bezuh, Dorotea Kelčec Ključarić

\section{ANALYSIS OF STRATEGIES APPLIED IN FILM TITLE TRANSLATION INTO THE CROATIAN AND GERMAN LANGUAGES}

Numerous authors have proposed that film titles have a notable role in understanding the film as a whole whereby they accentuate the appellative function of the title with the goal of convincing the addressee of the message to purchase the product. Since not only the text of the film but also the title is translated as a product for a targeted market, we have decided to conduct an analysis of the strategies on translating film titles into the Croatian and German languages. We have comprised two corpora consisting of original film titles (primarily in the English language) and their translations into the Croatian and German languages. In the first corpus, we analyse 935 translations of film titles which have been first screened in a time period from 1923 to 2015. The translations of the titles are categorized according to the applied translation strategies. The model of the strategies is formed by taking into consideration the manipulations through semantic and/or specific linguistic structures from the original. We also conduct a diachronic analysis of the first corpus in order to determine possible changes in the trends and we try to explain those changes. The second corpus is used for the analysis of the translations of horror and romantic comedy titles in order to determine if the genre influences the choice of the title translation strategy. We analyse the translations of approximately 80 original horror titles and approximately 60 romantic comedy titles according to the same principle as the translations from the first corpus. The results of our analysis suggest that there are differences in the selection of translation strategies for the Croatian and the German speaking markets. While the titles for the Croatian market are usually directly translated, the most common translation strategy for the German speaking market is the transcription of the original title, it is also common to add structures in German which are not present in the original. The analysis of horror and romantic comedy titles suggest that the genre also influences the selection of the translation strategy, with distinct differences between the two markets. 
KEY WORDS: film titles, translation strategies, appellative linguistic function, Croatian language, German language 
PRILOZI 
OPĆI KORPUS (ograničeno na engleske originalne naslove i njihove prijevode na hrvatski i njemački jezik)

\begin{tabular}{|c|c|c|c|}
\hline ORIGINALNI NASLOV & GODINA & HRVATSKI PRIJEVOD & NJEMAČKI PRIJEVOD \\
\hline Deadpool & 2016 & Deadpool & Deadpool \\
\hline Batman v Superman: Dawn of Justice & 2016 & Batman v Superman: Zora pravednika & Batman v Superman: Dawn of Justice \\
\hline Captain America: Civil War & 2016 & Kapetan Amerika: Građanski rat & The First Avenger: Civil War \\
\hline Suicide Squad & 2016 & Odred otpisanih & Suicide Squad \\
\hline Arrival & 2016 & Dolazak & Arrival \\
\hline Rogue One: A Star Wars Story & 2016 & Rogue One: Priča iz Ratova zvijezda & Rogue One: A Star Wars Story \\
\hline Zootopia & 2016 & Zootropola & Zoomania \\
\hline Doctor Strange & 2016 & Doktor Strange & Doctor Strange \\
\hline X-Men: Apocalypse & 2016 & X-Men: Apocalypse & X-Men: Apocalypse \\
\hline La La Land & 2016 & La La Land & La La Land \\
\hline $\begin{array}{l}\text { Star Wars: Episode VII - The Force } \\
\text { Awakens }\end{array}$ & 2015 & Ratovi zvijezda: Sila se budi & $\begin{array}{l}\text { Star Wars: Episode VII - Das Erwachen } \\
\text { der Macht }\end{array}$ \\
\hline Mad Max: Fury Road & 2015 & Pobješnjeli Max: Divlja cesta & Mad Max: Fury Road \\
\hline The Martian & 2015 & Marsovac & Der Marsianer - Rettet Mark Watney \\
\hline Avengers: Age of Ultron & 2015 & Osvetnici 2: Vladavina Ultrona & Avengers: Age of Ultron \\
\hline The Revenant & 2015 & Povratnik & The Revenant - Der Rückkehrer \\
\hline Jurassic World & 2015 & Jurski svijet & Jurassic World \\
\hline Inside Out & 2015 & Izvrnuto obrnuto & Alles steht Kopf \\
\hline Ant-Man & 2015 & Ant-Man & Ant-Man \\
\hline The Hateful Eight & 2015 & Mrska osmorka & The Hateful 8 \\
\hline Interstellar & 2014 & Interstellar & Interstellar \\
\hline Guardians of the Galaxy & 2014 & Čuvari galaksije & Guardians of the Galaxy \\
\hline Gone Girl & 2014 & Nestala & Gone Girl - Das perfekte Opfer \\
\hline X-Men: Days of Future Past & 2014 & X-Men: Dani buduće prošlosti & X-Men: Zukunft ist Vergangenheit \\
\hline Captain America: The Winter Soldier & 2014 & Kapetan Amerika: Ratnik zime & The Return of the First Avenger \\
\hline The Grand Budapest Hotel & 2014 & Hotel Grand Budapest & Grand Budapest Hotel \\
\hline The Imitation Game & 2014 & Igra oponašanja & $\begin{array}{l}\text { The Imitation Game - Ein streng } \\
\text { geheimes Leben }\end{array}$ \\
\hline Edge of Tomorrow & 2014 & Na rubu budućnosti & Edge of Tomorrow \\
\hline Whiplash & 2014 & Ritam ludila & Whiplash \\
\hline Kingsman: The Secret Service & 2014 & Kingsman: Tajna služba & Kingsman: The Secret Service \\
\hline The Wolf of Wall Street & 2013 & Vuk s Wall Streeta & The Wolf of Wall Street \\
\hline
\end{tabular}




\begin{tabular}{|c|c|c|c|}
\hline Gravity & 2013 & Gravitacija & Gravity \\
\hline Iron Man Three & 2013 & Iron Man 3 & Iron Man 3 \\
\hline Man of Steel & 2013 & Čovjek od čelika & Man of Steel \\
\hline The Hunger Games: Catching Fire & 2013 & Igre gladi: Plamen & Die Tribute von Panem - Catching Fire \\
\hline The Hobbit: The Desolation of Smaug & 2013 & Hobit: Smaugova pustoš & Der Hobbit: Smaugs Einöde \\
\hline World War Z & 2013 & Svjetski rat Z & World War Z \\
\hline Now You See Me & 2013 & Majstori iluzije & Die Unfassbaren - Now You See Me \\
\hline 12 Years a Slave & 2013 & 12 godina ropstva & 12 Years a Slave \\
\hline Frozen & 2013 & Snježno kraljevstvo & Die Eiskönigin - Völlig unverfroren \\
\hline The Dark Knight Rises & 2012 & Vitez tame: Povratak & The Dark Knight Rises \\
\hline The Avengers & 2012 & Osvetnici & The Avengers \\
\hline Django Unchained & 2012 & Odbjegli Django & Django Unchained \\
\hline The Hunger Games & 2012 & Igre gladi & $\begin{array}{l}\text { Die Tribute von Panem - The Hunger } \\
\text { Games }\end{array}$ \\
\hline The Hobbit: An Unexpected Journey & 2012 & Hobit: Neočekivano putovanje & Der Hobbit: Eine unerwartete Reise \\
\hline Silver Linings Playbook & 2012 & U dobru i u zlu & Silver Linings \\
\hline Skyfall & 2012 & Skyfall & James Bond 007 - Skyfall \\
\hline Ted & 2012 & Ted & Ted \\
\hline Prometheus & 2012 & Prometej & Prometheus - Dunkle Zeichen \\
\hline Argo & 2012 & Argo & Argo \\
\hline $\begin{array}{l}\text { Harry Potter and the Deathly Hollows: } \\
\text { Part } 2\end{array}$ & 2011 & Harry Potter i Darovi smrti 2. dio & $\begin{array}{l}\text { Harry Potter und die Heiligtümer des } \\
\text { Todes - Teil } 2\end{array}$ \\
\hline Thor & 2011 & Thor & Thor \\
\hline X: First Class & 2011 & X-Men: Prva generacija & X-Men: Erste Entscheidung \\
\hline Captain America: The First Avenger & 2011 & Kapetan Amerika: Prvi osvetnik & Captain America - The First Avenger \\
\hline Intouchables & 2011 & Nedodirljivi & Ziemlich beste Freunde \\
\hline Drive & 2011 & Vožnja & Drive \\
\hline Limitless & 2011 & Savršena formula & Ohne Limit \\
\hline Rise of the Planet of the Apes & 2011 & Planet majmuna: Postanak & Planet der Affen: Prevolution \\
\hline Source Code & 2011 & Izvorni kod & Source Code \\
\hline The Hangover Part II & 2011 & Mamurluk 2 & Hangover 2 \\
\hline Inception & 2010 & Početak & Inception \\
\hline Shutter Island & 2010 & Otok Shutter & Shutter Island \\
\hline Black Swan & 2010 & Crni labud & Black Swan \\
\hline Toy Story 3 & 2010 & Priča o igračkama 3 & Toy Story 3 \\
\hline Iron Man 2 & 2010 & Iron Man 2 & Iron Man 2 \\
\hline The King's Speech & 2010 & Kraljev govor & $\begin{array}{l}\text { The King's Speech - Die Rede des } \\
\text { Königs }\end{array}$ \\
\hline How to Train Your Dragon & 2010 & Kako izdresirati zmaja & Drachenzähmen leicht gemacht \\
\hline The Social Network & 2010 & Društvena mreža & The Social Network \\
\hline Kick-Ass & 2010 & Kick Ass & Kick-Ass \\
\hline
\end{tabular}




\begin{tabular}{|c|c|c|c|}
\hline Despicable Me & 2010 & Kako je Gru ukrao mjesec & Ich - Einfach unverbesserlich \\
\hline Inglourious Basterds & 2009 & Nemilosrdni gadovi & Inglourious Basterds \\
\hline Avatar & 2009 & Avatar & Avatar - Aufbruch nach Pandora \\
\hline Up & 2009 & Nebesa & Oben \\
\hline The Hangover & 2009 & Mamurluk & Hangover \\
\hline The District 9 & 2009 & Distrikt 9 & District 9 \\
\hline Star Trek & 2009 & Zvjezdane staze & Star Trek \\
\hline Sherlock Holmes & 2009 & Sherlock Holmes & Sherlock Holmes \\
\hline Watchmen & 2009 & Čuvari & Watchmen - Die Wächter \\
\hline Zombieland & 2009 & Dobrodošli u zemlju zombija & Zombieland \\
\hline (500) Days of Summer & 2009 & (500) dana ljubavi & (500) Days of Summer \\
\hline The Dark Knight & 2008 & Vitez tame & The Dark Knight \\
\hline $\mathrm{WALL} \cdot \mathrm{E}$ & 2008 & $\mathrm{WALL} \cdot \mathrm{E}$ & $\begin{array}{l}\text { WALL·E - Der Letzte räumt die Erde } \\
\text { auf }\end{array}$ \\
\hline Iron Man & 2008 & Iron Man & Iron Man \\
\hline Slumdog Millionaire & 2008 & Milijunaš s ulice & Slumdog Millionär \\
\hline Gran Torino & 2008 & Gran Torino & Gran Torino \\
\hline Taken & 2008 & 96 sati & 96 Hours \\
\hline The Curious Case of Benjamin Button & 2008 & Neobična priča o Benjaminu Buttonu & Der seltsame Fall des Benjamin Button \\
\hline Twilight & 2008 & Sumrak & Twilight - Biss zum Morgengrauen \\
\hline Hancock & 2008 & Hancock & Hancock \\
\hline $\begin{array}{l}\text { Indiana Jones and the Kingdom of the } \\
\text { Crystall Skull }\end{array}$ & 2008 & $\begin{array}{l}\text { Indiana Jones i Kraljevstvo kristalne } \\
\text { lubanje }\end{array}$ & $\begin{array}{l}\text { Indiana Jones und das Königreich des } \\
\text { Kristallschädels }\end{array}$ \\
\hline No Country for Old Men & 2007 & Nema zemlje za starce & No Country for Old Men \\
\hline I Am Legend & 2007 & Ja sam legenda & I Am Legend \\
\hline Transformers & 2007 & Transformeri & Transformers \\
\hline The Bourne Ultimatum & 2007 & Bourneov ultimatum & Das Bourne Ultimatum \\
\hline Ratatouille & 2007 & Juhu-hu & Ratatouille \\
\hline $\begin{array}{l}\text { Pirates of the Caribbean: At World's } \\
\text { End }\end{array}$ & 2007 & Pirati s Kariba: Na kraju svijeta & $\begin{array}{l}\text { Pirates of the Caribbean - Am Ende der } \\
\text { Welt }\end{array}$ \\
\hline Into the Wild & 2007 & U divljini & Into the Wild \\
\hline Superbad & 2007 & Superbad & Superbad \\
\hline Juno & 2007 & Juno & Juno \\
\hline Spider-Man 3 & 2007 & Spider-Man 3 & Spider-Man 3 \\
\hline The Departed & 2006 & Pokojni & Departed - Unter Feinden \\
\hline The Prestige & 2006 & Prestiž & Prestige - Die Meister der Magie \\
\hline 300 & 2006 & 300 & 300 \\
\hline $\begin{array}{l}\text { Pirates of the Caribbean: Dead Man's } \\
\text { Chest }\end{array}$ & 2006 & Pirati s Kariba: Mrtvačeva škrinja & $\begin{array}{l}\text { Pirates of the Caribbean - Fluch der } \\
\text { Karibik } 2\end{array}$ \\
\hline Blood Diamond & 2006 & Krvavi dijamant & Blood Diamond \\
\hline X-Men: The Last Stand & 2006 & X-Men: Posljednja fronta & X-Men: Der letzte Widerstand \\
\hline
\end{tabular}




\begin{tabular}{|c|c|c|c|}
\hline Children of Men & 2006 & Djeca čovječanstva & Children of Men \\
\hline Little Miss Sunshine & 2006 & Mala miss Amerike & Little Miss Sunshine \\
\hline Batman Begins & 2005 & Batman: Početak & Batman Begins \\
\hline V for Vendetta & 2005 & O za osvetu & V wie Vendetta \\
\hline Sin City & 2005 & Sin City & Sin City \\
\hline $\begin{array}{l}\text { Star Wars: Episode III-Revenge of the } \\
\text { Sith }\end{array}$ & 2005 & $\begin{array}{l}\text { Ratovi zvijezda: Epizoda III - Osveta } \\
\text { Sitha }\end{array}$ & $\begin{array}{l}\text { Star Wars: Episode III - Die Rache der } \\
\text { Sith }\end{array}$ \\
\hline Harry Potter and the Goblet of Fire & 2005 & Harry Potter i Plameni pehar & Harry Potter und der Feuerkelch \\
\hline Mr. \& Mrs. Smith & 2005 & Gospodin i gospođa Smith & Mr. \& Mrs. Smith \\
\hline War of the Worlds & 2005 & Rat svjetova & Krieg der Welten \\
\hline Charlie and the Chocolate Factory & 2005 & Charlie i tvornica čokolade & Charlie und die Schokoladenfabrik \\
\hline King Kong & 2005 & King Kong & King Kong \\
\hline The 40 Year Old Virgin & 2005 & Junfer u četrdesetoj & Jungfrau (40), männlich, sucht ... \\
\hline Eternal Sunshine of the Spotless Mind & 2004 & Vječni sjaj nepobjedivog uma & Vergiss mein nicht! \\
\hline Kill Bill: Vol. 2 & 2004 & Kill Bill 2 & Kill Bill - Volume 2 \\
\hline Million Dollar Baby & 2004 & Djevojka od milijun dolara & Million Dollar Baby \\
\hline The Incredibles & 2004 & Izbavitelji & Die Unglaublichen - The Incredibles \\
\hline Spider-Man 2 & 2004 & Spider-Man 2 & Spider-Man 2 \\
\hline The Notebook & 2004 & Zima za dvoje & Wie ein einziger Tag \\
\hline Shaun of the Dead & 2004 & Noć glupih mrtvaca & Shaun of the Dead \\
\hline I, Robot & 2004 & Ja, robot & I, Robot \\
\hline $\begin{array}{l}\text { Harry Potter and the Prisoner of } \\
\text { Azkaban }\end{array}$ & 2004 & Harry Potter i zatočenik Azkabana & $\begin{array}{l}\text { Harry Potter und der Gefangene von } \\
\text { Askaban }\end{array}$ \\
\hline Troy & 2004 & Troja & Troja \\
\hline $\begin{array}{l}\text { The Lord of the Rings: The Return of } \\
\text { the King }\end{array}$ & 2003 & Gospodar prstenova: Povratak kralja & $\begin{array}{l}\text { Der Herr der Ringe: Die Rückkehr des } \\
\text { Königs }\end{array}$ \\
\hline $\begin{array}{l}\text { Pirates of the Caribbean: The Curse of } \\
\text { the Black Pearl }\end{array}$ & 2003 & Pirati s Kariba & Fluch der Karibik \\
\hline Kill Bill: Vol. 1 & 2003 & Kill Bill & Kill Bill: Volume 1 \\
\hline Finding Nemo & 2003 & Potraga za Nemom & Findet Nemo \\
\hline The Matrix Reloaded & 2003 & Matrix Reloaded & Matrix Reloaded \\
\hline $\mathrm{X} 2$ & 2003 & X-Men 2 & X-Men 2 \\
\hline The Matrix Revolutions & 2003 & Matrix: Revolutions & Matrix Revolutions \\
\hline Big Fish & 2003 & Krupna riba & Big Fish \\
\hline Mystic River & 2003 & Mistična rijeka & Mystic River \\
\hline $\begin{array}{l}\text { The Lord of the Rings: The Two } \\
\text { Towers }\end{array}$ & 2002 & Gospodar prstenova: Dvije kule & Der Herr der Ringe: Die zwei Türme \\
\hline Spider-Man & 2002 & Spider-man & Spider-Man \\
\hline Catch Me If You Can & 2002 & Uhvati me ako možeš & Catch Me If You Can \\
\hline The Pianist & 2002 & Pijanist & Der Pianist \\
\hline Star Wars: Episode II - Attack of the & 2002 & Zvjezdani ratovi epizoda II: Klonovi & Star Wars: Episode II - Angriff der \\
\hline
\end{tabular}




\begin{tabular}{|c|c|c|c|}
\hline Clones & & napadaju & Klonkrieger \\
\hline The Bourne Identity & 2002 & Bourneov identitet & Die Bourne Identität \\
\hline Minority Report & 2002 & Specijalni izvještaj & Minority Report \\
\hline $\begin{array}{l}\text { Harry Potter and the Chamber of } \\
\text { Secrets }\end{array}$ & 2002 & Harry Potter i odaja tajni & $\begin{array}{l}\text { Harry Potter und die Kammer des } \\
\text { Schreckens }\end{array}$ \\
\hline Ice Age & 2002 & Ledeno doba & Ice Age \\
\hline $\begin{array}{l}\text { The Lord of the Rings: The Fellowship } \\
\text { of the Ring }\end{array}$ & 2001 & Gospodar prstenova: Prstenova družina & Der Herr der Ringe: Die Gefährten \\
\hline A Beautiful Mind & 2001 & Genijalni um & $\begin{array}{l}\text { A Beautiful Mind - Genie und } \\
\text { Wahnsinn }\end{array}$ \\
\hline Monsters, Inc. & 2001 & Čudovišta iz ormara & Die Monster AG \\
\hline Donnie Darko & 2001 & Donnie Darko & Donnie Darko \\
\hline Shrek & 2001 & Shrek & Shrek - Der tollkühne Held \\
\hline Harry Potter and the Sorcerer's Stone & 2001 & Harry Potter i kamen mudraca & Harry Potter und der Stein der Weisen \\
\hline Ocean's Eleven & 2001 & Oceanovih jedanaest & Ocean's Eleven \\
\hline Training Day & 2001 & Dan obuke & Training Day \\
\hline Gladiator & 2000 & Gladijator & Gladiator \\
\hline Memento & 2000 & Memento & Memento \\
\hline Snatch & 2000 & Zdrpi i briši & Snatch - Schweine und Diamanten \\
\hline Requiem for a Dream & 2000 & Rekvijem za snove & Requiem for a Dream \\
\hline X-Men & 2000 & X-Men & X-Men - Der Film \\
\hline Cast Away & 2000 & Brodolom života & Cast Away - Verschollen \\
\hline American Psycho & 2000 & Američki psiho & American Psycho \\
\hline Meet the Parents & 2000 & Dozvola za brak & Meine Braut, ihr Vater und ich \\
\hline Unbreakable & 2000 & Neslomljivi & Unbreakable - Unzerbrechlich \\
\hline Mission: Impossible II & 2000 & Nemoguća misija 2 & Mission: Impossible 2 \\
\hline Fight Club & 1999 & Klub boraca & Fight Club \\
\hline The Matrix & 1999 & Matrix & Matrix \\
\hline American Beauty & 1999 & Vrtlog života & American Beauty \\
\hline The Green Mile & 1999 & Zelena milja & The Green Mile \\
\hline The Sixth Sense & 1999 & Šesto čulo & The Sixth Sense \\
\hline $\begin{array}{l}\text { Star Wars: Episode I - The Phantom } \\
\text { Menace }\end{array}$ & 1999 & $\begin{array}{l}\text { Ratovi zvijezda Epizoda 1: Fantomska } \\
\text { prijetnja }\end{array}$ & $\begin{array}{l}\text { Star Wars: Episode I - Die dunkle } \\
\text { Bedrohung }\end{array}$ \\
\hline Toy Story 2 & 1999 & Priča o igračkama 2 & Toy Story 2 \\
\hline The Mummy & 1999 & Mumija & Die Mumie \\
\hline American Pie & 1999 & Američka pita & $\begin{array}{l}\text { American Pie - Wie ein heißer } \\
\text { Apfelkuchen }\end{array}$ \\
\hline Sleepy Hollow & 1999 & Sanjiva dolina & Sleepy Hollow \\
\hline Saving Private Ryan & 1998 & Spašavanje vojnika Ryana & Der Soldat James Ryan \\
\hline American History X & 1998 & Generacija X & American History X \\
\hline The Truman Show & 1998 & Trumanov šou & Die Truman Show \\
\hline
\end{tabular}




\begin{tabular}{|c|c|c|c|}
\hline The Big Lebowski & 1998 & Veliki Lebowski & The Big Lebowski \\
\hline $\begin{array}{l}\text { Lock, Stock and the Two Smoking } \\
\text { Barrels }\end{array}$ & 1998 & Lopovi, ubojice i dvije nabijene puške & Bube Dame König GrAs \\
\hline Armageddon & 1998 & Armageddon & Armageddon - Das jüngste Gericht \\
\hline There's Something About Mary & 1998 & Svi su ludi za Mary & Verrückt nach Mary \\
\hline Fear and Loathing in Las Vegas & 1998 & Strah i prezir u Las Vegasu & Fear and Loathing in Las Vegas \\
\hline A Bug's Life & 1998 & Život buba & Das große Krabbeln \\
\hline Blade & 1998 & Blade & Blade \\
\hline Titanic & 1997 & Titanic & Titanic \\
\hline Good Will Hunting & 1997 & Dobri Will Hunting & Good Will Hunting \\
\hline L.A. Confidential & 1997 & L.A. povjerljivo & L.A. Confidential \\
\hline Men in Black & 1997 & Ljudi u crnom & Men in Black \\
\hline The Fifth Element & 1997 & Peti element & Das fünfte Element \\
\hline Face/Off & 1997 & Čovjek bez lica & Im Körper des Feindes \\
\hline The Lost World: Jurassic Park & 1997 & Jurski park 2: Izgubljeni svijet & Vergessene Welt - Jurassic Park \\
\hline The Game & 1997 & Igra & The Game \\
\hline The Devil's Advocate & 1997 & Đavolji odvjetnik & Im Auftrag des Teufels \\
\hline Trainspotting & 1996 & Trainspotting & Trainspotting - Neue Helden \\
\hline Fargo & 1996 & Fargo & Fargo \\
\hline Independence Day & 1996 & Dan nezavisnosti & Independence Day \\
\hline Mission: Impossible & 1996 & Nemoguća misija & Mission: Impossible \\
\hline The Rock & 1996 & Hrid & The Rock - Fels der Entscheidung \\
\hline Scream & 1996 & Vrisak & Scream - Schrei! \\
\hline From Dusk Till Dawn & 1996 & Od sumraka do zore & From Dusk Till Dawn \\
\hline Jerry Maguire & 1996 & Jerry Maguire & Jerry Maguire - Spiel des Lebens \\
\hline Mars Attacks! & 1996 & Mars napada & Mars Attacks! \\
\hline Romeo + Juliet & 1996 & Romeo i Julija & William Shakespeares Romeo + Julia \\
\hline Se7en & 1995 & Sedam & Sieben \\
\hline The Usual Suspects & 1995 & Privedite osumnjičene & Die üblichen Verdächtigen \\
\hline Braveheart & 1995 & Hrabro srce & Braveheart \\
\hline Toy Story & 1995 & Priča o igračkama & Toy Story \\
\hline Twelve Monkeys & 1995 & 12 majmuna & 12 Monkeys \\
\hline Heat & 1995 & Vrućina & Heat \\
\hline Casino & 1995 & Kasino & Casino \\
\hline Die Hard with a Vengeance & 1995 & Umri muški 3 & Stirb langsam - Jetzt erst recht \\
\hline Apollo 13 & 1995 & Apollo 13 & Apollo 13 \\
\hline Jumanji & 1995 & Jumanji & Jumanji \\
\hline The Shawshank Redemption & 1994 & Iskupljenje u Shawshanku & Die Verurteilten \\
\hline Pulp Fiction & 1994 & Pakleni šund & Pulp Fiction \\
\hline Forrest Gump & 1994 & Forrest Gump & Forrest Gump \\
\hline
\end{tabular}




\begin{tabular}{|c|c|c|c|}
\hline The Lion King & 1994 & Kralj lavova & Der König der Löwen \\
\hline Dumb \& Dumber & 1994 & Glup i gluplji & Dumm und Dümmer \\
\hline The Mask & 1994 & Maska & Die Maske \\
\hline Speed & 1994 & Brzina & Speed \\
\hline $\begin{array}{l}\text { Interview with the Vampire: The } \\
\text { Vampire Chronicles }\end{array}$ & 1994 & Intervju s vampirom & Interview mit einem Vampir \\
\hline Ace Ventura: Pet Detective & 1994 & Ace Ventura: Šašavi detektiv & Ace Ventura - Ein tierischer Detektiv \\
\hline Schindler's List & 1993 & Schindlerova lista & Schindlers Liste \\
\hline Jurassic Park & 1993 & Jurski park & Jurassic Park \\
\hline Groundhog Day & 1993 & Beskrajni dan & Und täglich grüßt das Murmeltier \\
\hline The Nightmare Before Christmas & 1993 & Predbožićna noćna mora & Nightmare Before Christmas \\
\hline The Fugitive & 1993 & Bjegunac & Auf der Flucht \\
\hline Mrs. Doubtfire & 1993 & Tatica u suknji & $\begin{array}{l}\text { Mrs. Doubtfire - Das stachelige } \\
\text { Kindermädchen }\end{array}$ \\
\hline Clerks & 1993 & Trgovci & Clerks - Die Ladenhüter \\
\hline Philadelphia & 1993 & Philadelphia & Philadelphia \\
\hline What's Eating Gilbert Grape & 1993 & Što muči Gilberta Grapea & Gilbert Grape - Irgendwo in Iowa \\
\hline True Romance & 1993 & True Romance & True Romance \\
\hline Reservoir Dogs & 1992 & Psi iz rezervoara & Reservoir Dogs \\
\hline Unforgiven & 1992 & Nepomirljivi & Erbarmungslos \\
\hline Aladdin & 1992 & Aladdin & Aladdin \\
\hline Batman Returns & 1992 & Batman se vraća & Batmans Rückkehr \\
\hline Alien $^{3}$ & 1992 & Alien 3 & Alien $^{3}$ \\
\hline Home Alone 2: Lost in New York & 1992 & Sam u kući 2 & Kevin - Allein in New York \\
\hline Scent of a Woman & 1992 & Miris žene & Der Duft der Frauen \\
\hline A Few Good Men & 1992 & Malo dobrih ljudi & Eine Frage der Ehre \\
\hline Dracula & 1992 & Drakula & Bram Stoker's Dracula \\
\hline Basic Instinct & 1992 & Sirove strasti & Basic Instinct \\
\hline The Silence of the Lambs & 1991 & Kad jaganjci utihnu & Das Schweigen der Lämmer \\
\hline Terminator 2: Judgment Day & 1991 & Terminator 2: Sudnji dan & Terminator 2 - Tag der Abrechnung \\
\hline Beauty and the Beast & 1991 & Ljepotica i zvijer & Die Schöne und das Biest \\
\hline Hook & 1991 & Kapetan Kuka & Hook \\
\hline Robin Hood: Prince of Thieves & 1991 & Robin Hood: Princ lopova & Robin Hood - König der Diebe \\
\hline Cape Fear & 1991 & Rt straha & Kap der Angst \\
\hline Point Break & 1991 & Pakleni val & Gefährliche Brandung \\
\hline JFK & 1991 & JFK & JFK - Tatort Dallas \\
\hline Thelma \& Louise & 1991 & Thelma i Louise & Thelma \& Louise \\
\hline The Addams Family & 1991 & Obitelj Adams & Die Addams Family \\
\hline Goodfellas & 1990 & Dobri momci & $\begin{array}{l}\text { GoodFellas - Drei Jahrzehnte in der } \\
\text { Mafia }\end{array}$ \\
\hline Edward Scissorhands & 1990 & Edward Škaroruki & Edward mit den Scherenhänden \\
\hline
\end{tabular}




\begin{tabular}{|c|c|c|c|}
\hline Home Alone & 1990 & Sam u kući & Kevin - Allein zu Haus \\
\hline Back to the Future Part III & 1990 & Povratak u budućnost III & Zurück in die Zukunft III \\
\hline Die Hard 2 & 1990 & Umri muški 2 & Stirb langsam 2 \\
\hline The Godfather: Part III & 1990 & Kum 3 & Der Pate 3 \\
\hline Total Recall & 1990 & Totalni opoziv & Die totale Erinnerung - Total Recall \\
\hline Pretty Woman & 1990 & Zgodna žena & Pretty Woman \\
\hline Dances with Wolves & 1990 & Ples s vukovima & Der mit dem Wolf tanzt \\
\hline Ghost & 1990 & Duh & Ghost - Nachricht von Sam \\
\hline Indiana Jones and the Last Crusade & 1989 & $\begin{array}{l}\text { Indiana Jones i Posljednji križarski } \\
\text { pohod }\end{array}$ & Indiana Jones und der letzte Kreuzzug \\
\hline Back to the Future Part II & 1989 & Povratak u budućnost II & Zurück in die Zukunft II \\
\hline Dead Poets Society & 1989 & Društvo mrtvih pjesnika & Der Club der toten Dichter \\
\hline Batman & 1989 & Batman & Batman \\
\hline The Little Mermaid & 1989 & Mala sirena & Arielle, die Meerjungfrau \\
\hline When Harry Met Sally... & 1989 & Kad je Harry sreo Sally & Harry und Sally \\
\hline Ghostbusters II & 1989 & Istjerivači duhova 2 & Ghostbusters 2 \\
\hline The Abyss & 1989 & Bezdan & The Abyss \\
\hline Lethal Weapon 2 & 1989 & Smrtonosno oružje 2 & Lethal Weapon 2 - Brennpunkt L.A. \\
\hline Honey, I Shrunk the Kids & 1989 & Draga, smanjio sam djecu & $\begin{array}{l}\text { Liebling, ich habe die Kinder } \\
\text { geschrumpft }\end{array}$ \\
\hline Die Hard & 1988 & Umri muški & Stirb langsam \\
\hline Rain Man & 1988 & Kišni čovjek & Rain Man \\
\hline Beetlejuice & 1988 & Bubimir & Beetlejuice \\
\hline Big & 1988 & Veliki & Big \\
\hline Who Framed Roger Rabbit & 1988 & Tko je smjestio zeki Rogeru? & Falsches Spiel mit Roger Rabbit \\
\hline Coming to America & 1988 & Princ otkriva Ameriku & Der Prinz aus Zamunda \\
\hline $\begin{array}{l}\text { The Naked Gun: From the Files of } \\
\text { Police Squad! }\end{array}$ & 1988 & Goli pištolj & Die nackte Kanone \\
\hline Full Metal Jacket & 1987 & Full Metal Jacket & Full Metal Jacket \\
\hline The Princess Bride & 1987 & Kraljevna nevjesta & Die Braut des Prinzen \\
\hline Predator & 1987 & Predator & Predator \\
\hline The Untouchables & 1987 & Nedodirljivi & $\begin{array}{l}\text { The Untouchables - Die } \\
\text { Unbestechlichen }\end{array}$ \\
\hline Lethal Weapon & 1987 & Smrtonosno oružje & Lethal Weapon - Zwei stahlharte Profis \\
\hline RoboCop & 1987 & Robocop & RoboCop \\
\hline Dirty Dancing & 1987 & Prljavi ples & Dirty Dancing \\
\hline Spaceballs & 1987 & Svemirske lopte & Spaceballs \\
\hline Wall Street & 1987 & Wall Street & Wall Street \\
\hline Evil Dead II & 1987 & Zla smrt II & $\begin{array}{l}\text { Tanz der Teufel } 2 \text { - Jetzt wird noch } \\
\text { mehr getanzt }\end{array}$ \\
\hline Aliens & 1986 & Alien 2 & Aliens - Die Rückkehr \\
\hline
\end{tabular}




\begin{tabular}{|c|c|c|c|}
\hline Platoon & 1986 & Vod smrti & Platoon \\
\hline Stand by Me & 1986 & Ostani uz mene & $\begin{array}{l}\text { Stand by Me - Das Geheimnis eines } \\
\text { Sommers }\end{array}$ \\
\hline Ferris Bueller's Day Off & 1986 & Slobodan dan Ferrisa Buellera & Ferris macht blau \\
\hline Top Gun & 1986 & Top Gun & $\begin{array}{l}\text { Top Gun - Sie fürchten weder Tod noch } \\
\text { Teufel }\end{array}$ \\
\hline Blue Velvet & 1986 & Plavi baršun & Blue Velvet \\
\hline The Fly & 1986 & Muha & Die Fliege \\
\hline Highlander & 1986 & Gorštak & Highlander - Es kann nur einen geben \\
\hline Labyrinth & 1986 & Labirint & Die Reise ins Labyrinth \\
\hline Back to the Future & 1985 & Povratak u budućnost & Zurück in die Zukunft \\
\hline The Breakfast Club & 1985 & Klub ranoranilaca & Breakfast Club - Der Frühstücksclub \\
\hline The Goonies & 1985 & Goonies & Die Goonies \\
\hline Brazil & 1985 & Brazil & Brazil \\
\hline Rocky IV & 1985 & Rocky 4 & $\begin{array}{l}\text { Rocky IV - Der Kampf des } \\
\text { Jahrhunderts }\end{array}$ \\
\hline Rambo: First Blood Part II & 1985 & Rambo 2 & Rambo II - Der Auftrag \\
\hline Commando & 1985 & Komandos & Das Phantom Kommando \\
\hline Mad Max Beyond Thunderdome & 1985 & Pobješnjeli Max 3 & $\begin{array}{l}\text { Mad Max III - Jenseits der } \\
\text { Donnerkuppel }\end{array}$ \\
\hline A View to Kill & 1985 & Pogled na ubojstvo & $\begin{array}{l}\text { James Bond } 007 \text { - Im Angesicht des } \\
\text { Todes }\end{array}$ \\
\hline The Terminator & 1984 & Terminator & Terminator \\
\hline Indiana Jones and the Temple of Doom & 1984 & Indiana Jones i ukleti hram & $\begin{array}{l}\text { Indiana Jones und der Tempel des } \\
\text { Todes }\end{array}$ \\
\hline Ghostbusters & 1984 & Istjerivači duhova & Ghostbusters - Die Geisterjäger \\
\hline Once Upon a Time in America & 1984 & Bilo jednom u Americi & Es war einmal in Amerika \\
\hline A Nightmare on Elm Street & 1984 & Strava u ulici Brijestova & Nightmare - Mörderische Träume \\
\hline Gremlins & 1984 & Gremlini & Gremlins - Kleine Monster \\
\hline The Karate Kid & 1984 & Karate Kid & Karate Kid \\
\hline Beverly Hills Cop & 1984 & Policajac s Beverly Hillsa & $\begin{array}{l}\text { Beverly Hills Cop - Ich lös' den Fall auf } \\
\text { jeden Fall }\end{array}$ \\
\hline This Is Spinal Tap & 1984 & Ovo je Spinal Tap & This Is Spinal Tap \\
\hline $\begin{array}{l}\text { Star Wars: Episode VI - Return of the } \\
\text { Jedi }\end{array}$ & 1983 & Zvjezdani ratovi VI: Povratak Jedija & Die Rückkehr der Jedi-Ritter \\
\hline Scarface & 1983 & Lice s ožiljkom & Scarface \\
\hline A Christmas Story & 1983 & Božićna priča & Fröhliche Weihnachten \\
\hline Trading Places & 1983 & Kolo sreće & Die Glücksritter \\
\hline The Meaning of Life & 1983 & Monty Python: Smisao života & Der Sinn des Lebens \\
\hline Octopussy & 1983 & James Bond: Octopussy & James Bond 007 - Octopussy \\
\hline WarGames & 1983 & Ratne igre & WarGames - Kriegsspiele \\
\hline
\end{tabular}




\begin{tabular}{|c|c|c|c|}
\hline National Lampoon's Vacation & 1983 & Godišnji odmor snova & Die schrillen Vier auf Achse \\
\hline Videodrome & 1983 & Videodrom & Videodrome \\
\hline Risky Business & 1983 & Riskantan posao & Lockere Geschäfte \\
\hline Blade Runner & 1982 & Istrebljivač & Blade Runner \\
\hline E.T. the Extra-Terrestrial & 1982 & E.T. & E.T. - Der Außerirdische \\
\hline The Thing & 1982 & Stvor & Das Ding aus einer anderen Welt \\
\hline First Blood & 1982 & Rambo & Rambo \\
\hline Rocky III & 1982 & Rocky 3 & Rocky III - Das Auge des Tigers \\
\hline Conan the Barbarian & 1982 & Konan Barbarin & Conan der Barbar \\
\hline Poltergeist & 1982 & Poltergeist & Poltergeist \\
\hline TRON & 1982 & Tron & Tron \\
\hline Star Trek: The Wrath of Khan & 1982 & Zvjezdane staze II: Khanov bijes & Star Trek II: Der Zorn des Khan \\
\hline Raiders of the Lost Ark & 1981 & $\begin{array}{l}\text { Indiana Jones: Otimači izgubljenog } \\
\text { kovčega }\end{array}$ & Jäger des verlorenen Schatzes \\
\hline The Evil Dead & 1981 & Zla smrt & Tanz der Teufel \\
\hline Mad Max 2 & 1981 & Pobješnjeli Max 2 & Mad Max II - Der Vollstrecker \\
\hline Escape from New York & 1981 & Bijeg iz New Yorka & Die Klapperschlange \\
\hline For Your Eyes Only & 1981 & James Bond 007: Samo za tvoje oči & James Bond 007 - In tödlicher Mission \\
\hline An American Werewolf in London & 1981 & Američki vukodlak u Londonu & American Werewolf \\
\hline The Fox and the Hound & 1981 & Lisica i pas & Cap und Capper \\
\hline Halloween II & 1981 & Noć vještica 2 & $\begin{array}{l}\text { Halloween II - Das Grauen kehrt } \\
\text { zurück }\end{array}$ \\
\hline Stripes & 1981 & Vojničine & Ich glaub' mich knutscht ein Elch! \\
\hline $\begin{array}{l}\text { Star Wars: Episode V - The Empire } \\
\text { Strikes Back }\end{array}$ & 1980 & $\begin{array}{l}\text { Zvjezdani ratovi V: Carstvo uzvraća } \\
\text { udarac }\end{array}$ & Das Imperium schlägt zurück \\
\hline The Shining & 1980 & Isijavanje & Shining \\
\hline Raging Bull & 1980 & Razjareni bik & Wie ein wilder Stier \\
\hline The Elephant Man & 1980 & Čovjek slon & Der Elefantenmensch \\
\hline Airplane! & 1980 & Ima li pilota u avionu & $\begin{array}{l}\text { Die unglaubliche Reise in einem } \\
\text { verrückten Flugzeug }\end{array}$ \\
\hline The Blues Brothers & 1980 & Braća Blues & Blues Brothers \\
\hline Friday the 13th & 1980 & Petak 13-ti & Freitag der 13. \\
\hline Caddyshack & 1980 & Golf klub & $\begin{array}{l}\text { Caddyshack - Wahnsinn ohne } \\
\text { Handicap }\end{array}$ \\
\hline Superman II & 1980 & Superman 2 & Superman II - Allein gegen alle \\
\hline The Blue Lagoon & 1980 & Plava laguna & Die blaue Lagune \\
\hline Alien & 1979 & Alien: Osmi putnik & $\begin{array}{l}\text { Alien - Das unheimliche Wesen aus } \\
\text { einer fremden Welt }\end{array}$ \\
\hline Apocalypse Now & 1979 & Apokalipsa danas & Apocalypse Now \\
\hline Life of Brian & 1979 & Brianov život & Das Leben des Brian \\
\hline Mad Max & 1979 & Pobješnjeli Max & Mad Max \\
\hline
\end{tabular}




\begin{tabular}{|c|c|c|c|}
\hline Rocky II & 1979 & Rocky 2 & Rocky II \\
\hline Manhattan & 1979 & Manhattan & Manhattan \\
\hline Kramer vs. Kramer & 1979 & Kramer protiv Kramera & Kramer gegen Kramer \\
\hline Escape from Alcatraz & 1979 & Bijeg iz Alcatraza & Flucht von Alcatraz \\
\hline The Warriors & 1979 & Ratnici podzemlja & Die Warriors \\
\hline Moonraker & 1979 & James Bond 007: Operacija svemir & $\begin{array}{l}\text { James Bond } 007 \text { - Moonraker - Streng } \\
\text { geheim }\end{array}$ \\
\hline The Deer Hunter & 1978 & Lovac na jelene & Die durch die Hölle gehen \\
\hline Grease & 1978 & Briljantin & Grease \\
\hline Halloween & 1978 & Noć vještica & Halloween - Die Nacht des Grauens \\
\hline Superman & 1978 & Superman & Superman \\
\hline Animal House & 1978 & Zvjerinjak & Ich glaub, mich tritt ein Pferd \\
\hline Dawn of the Dead & 1978 & Zora živih mrtvaca & Zombie - Dawn of the Dead \\
\hline Midnight Express & 1978 & Ponoćni ekspres & 12 Uhr nachts - Midnight Express \\
\hline Jaws 2 & 1978 & Ralje 2 & Der weiße Hai 2 \\
\hline Days of Heaven & 1978 & Nebeski dani & In der Glut des Südens \\
\hline Invasion of the Body Snatchers & 1978 & Invazija tjelokradica & Die Körperfresser kommen \\
\hline Star Wars & 1977 & $\begin{array}{l}\text { Zvjezdani ratovi Epizoda IV: Nova } \\
\text { nada }\end{array}$ & Krieg der Sterne \\
\hline Annie Hall & 1977 & Annie Hall & Der Stadtneurotiker \\
\hline Close Encounters of the Third Kind & 1977 & Bliski susreti treće vrste & Unheimliche Begegnung der dritten Art \\
\hline The Spy Who Loved Me & 1977 & James Bond 007: Špijun koji me volio & $\begin{array}{l}\text { James Bond } 007 \text { - Der Spion, der mich } \\
\text { liebte }\end{array}$ \\
\hline Eraserhead & 1977 & Eraserhead & Eraserhead \\
\hline Saturday Night Fever & 1977 & Groznica subotnje večeri & Nur Samstag Nacht \\
\hline The Rescuers & 1977 & Spasitelji & Bernard und Bianca - Die Mäusepolizei \\
\hline A Bridge Too Far & 1977 & Nedostižni most & Die Brücke von Arnheim \\
\hline Smokey and the Bandit & 1977 & Smokey i Bandit & Ein ausgekochtes Schlitzohr \\
\hline Taxi Driver & 1976 & Taksist & Taxi Driver \\
\hline Rocky & 1976 & Rocky & Rocky \\
\hline Carrie & 1976 & Carrie & Carrie - Des Satans jüngste Tochter \\
\hline Network & 1976 & TV mreža & Network \\
\hline The Omen & 1976 & Pretkazanje & Das Omen \\
\hline All the President's Men & 1976 & Svi predsjednikovi ljudi & Die Unbestechlichen \\
\hline The Outlaw Josey Wales & 1976 & Odmetnik Josey Wales & Der Texaner \\
\hline Marathon Man & 1976 & Maratonac & Der Marathon-Mann \\
\hline Logan's Run & 1976 & Loganov bijeg & Flucht ins 23. Jahrhundert \\
\hline The Enforcer & 1976 & Istjerivač pravde & Dirty Harry III - Der Unerbittliche \\
\hline One Flew Over the Cuckoo's Nest & 1975 & Let iznad kukavičjeg gnijezda & Einer flog über das Kuckucksnest \\
\hline Jaws & 1975 & Ralje & Der weiße Hai \\
\hline Monty Python and the Holy Grail & 1975 & Monty Python i Sveti gral & Die Ritter der Kokosnuß \\
\hline
\end{tabular}




\begin{tabular}{|c|c|c|c|}
\hline Dog Day Afternoon & 1975 & Pasje poslijepodne & Hundstage \\
\hline The Rocky Horror Picture Show & 1975 & Rocky Horror Picture Show & The Rocky Horror Picture Show \\
\hline Barry Lyndon & 1975 & Barry Lyndon & Barry Lyndon \\
\hline The Man Who Would Be King & 1975 & Covjek koji je htio biti kralj & Der Mann, der König sein wollte \\
\hline Three Days of the Condor & 1975 & Tri dana Kondora & Die drei Tage des Condor \\
\hline The Godfather: Part II & 1974 & Kum 2 & Der Pate 2 \\
\hline Chinatown & 1974 & Kineska četvrt & Chinatown \\
\hline Young Frankenstein & 1974 & Mladi Frankenstein & Frankenstein Junior \\
\hline The Texas Chain Saw Massacre & 1974 & Teksaški masakr motornom pilom & Blutgericht in Texas \\
\hline Blazing Saddles & 1974 & Vruća sedla & Der Wilde Wilde Westen \\
\hline The Conversation & 1974 & Prisluškivanje & Der Dialog \\
\hline The Man with the Golden Gun & 1974 & $\begin{array}{l}\text { James Bond 007: Čovjek sa zlatnim } \\
\text { pištoljem }\end{array}$ & $\begin{array}{l}\text { James Bond } 007 \text { - Der Mann mit dem } \\
\text { goldenen Colt }\end{array}$ \\
\hline Murder on the Orient Express & 1974 & Ubojstvo u Orient Expressu & Mord im Orient Express \\
\hline The Towering Inferno & 1974 & Pakleni toranj & Flammendes Inferno \\
\hline Death Wish & 1974 & Smrtonosna želja & Ein Mann sieht rot \\
\hline The Exorcist & 1973 & Istjerivač đavola & Der Exorzist \\
\hline The Sting & 1973 & Žalac & Der Clou \\
\hline Robin Hood & 1973 & Robin Hood & Robin Hood \\
\hline Serpico & 1973 & Serpico & Serpico \\
\hline Enter the Dragon & 1973 & U zmajevom gnijezdu & Der Mann mit der Todeskralle \\
\hline Live and Let Die & 1973 & James Bond: Živi i pusti umrijeti & $\begin{array}{l}\text { James Bond } 007 \text { - Leben und sterben } \\
\text { lassen }\end{array}$ \\
\hline Mean Streets & 1973 & Ulice nasilja & Hexenkessel \\
\hline American Graffiti & 1973 & Američki grafiti & American Graffiti \\
\hline The Wicker Man & 1973 & Čovjek od pruća & The Wicker Man \\
\hline The Godfather & 1972 & Kum & Der Pate \\
\hline Deliverance & 1972 & Oslobađanje & Beim Sterben ist jeder der Erste \\
\hline Sleuth & 1972 & Njuškalo & Mord mit kleinen Fehlern \\
\hline Cabaret & 1972 & Kabaret & Cabaret \\
\hline The Poseidon Adventure & 1972 & Posejdonova avantura & Die Höllenfahrt der Poseidon \\
\hline $\begin{array}{l}\text { Everything You Always Wanted to } \\
\text { Know About Sex * But Were Afraid to } \\
\text { Ask }\end{array}$ & 1972 & Sve što ste željeli znati o seksu & $\begin{array}{l}\text { Was Sie schon immer über Sex wissen } \\
\text { wollten }\end{array}$ \\
\hline Frenzy & 1972 & Mahnitost & Frenzy \\
\hline A Clockwork Orange & 1971 & Paklena naranča & Uhrwerk Orange \\
\hline Willy Wonka \& the Chocolate Factory & 1971 & Willy Wonka i tvornica čokolade & Charlie und die Schokoladenfabrik \\
\hline Dirty Harry & 1971 & Prljavi Harry & Dirty Harry \\
\hline The French Connection & 1971 & Francuska veza & $\begin{array}{l}\text { French Connection - Brennpunkt } \\
\text { Brooklyn }\end{array}$ \\
\hline Diamonds are Forever & 1971 & Dijamanti su vječni & James Bond 007 - Diamantenfieber \\
\hline
\end{tabular}




\begin{tabular}{|c|c|c|c|}
\hline Harold and Maude & 1971 & Harold i Maude & Harold and Maude \\
\hline Duel & 1971 & Dvoboj & Duell \\
\hline Straw Dogs & 1971 & Psi od slame & Wer Gewalt sät \\
\hline The Last Picture Show & 1971 & Posljednja kino predstava & Die letzte Vorstellung \\
\hline The AristoCats & 1970 & Mačke iz visokog društva & Aristocats \\
\hline MASH & 1970 & M.A.S.H. & M.A.S.H. \\
\hline Kelly's Heroes & 1970 & Zlato za odvažne & Stoßtrupp Gold \\
\hline Beneath the Planet of the Apes & 1970 & Ispod planeta majmuna & Rückkehr zum Planet der Affen \\
\hline Little Big Man & 1970 & Mali veliki čovjek & Little Big Man \\
\hline Five Easy Pieces & 1970 & Pet lakih komada & Ein Mann sucht sich selbst \\
\hline Love Story & 1970 & Ljubavna priča & Love Story \\
\hline Midnight Cowboy & 1969 & Ponoćni kauboj & Asphalt-Cowboy \\
\hline Easy Rider & 1969 & Goli u sedlu & Easy Rider \\
\hline The Wild Bunch & 1969 & Divlja horda & $\begin{array}{l}\text { The Wild Bunch - Sie kannten kein } \\
\text { Gesetz }\end{array}$ \\
\hline On Her Majesty's Secret Service & 1969 & U službi njenog veličanstva & $\begin{array}{l}\text { James Bond } 007 \text { - Im Geheimdienst } \\
\text { Ihrer Majestät }\end{array}$ \\
\hline True Gift & 1969 & Covjek zvan Hrabrost & Der Marshal \\
\hline Take the Money and Run & 1969 & Uzmi novac i bježi & Woody, der Unglücksrabe \\
\hline Battle of Britain & 1969 & Bitka za Britaniju & Luftschlacht um England \\
\hline 2001: A Space Odyssey & 1968 & 2001: Odiseja u svemiru & 2001: Odyssee im Weltraum \\
\hline Rosemary's Baby & 1968 & Rosemaryna beba & Rosemaries Baby \\
\hline Planet of the Apes & 1968 & Planet majmuna & Planet der Affen \\
\hline Night of the Living Dead & 1968 & Noć živih mrtvaca & Die Nacht der lebenden Toten \\
\hline Where Eagle Dares & 1968 & Orlovo gnijezdo & Agenten sterben einsam \\
\hline Chitty Chitty Bang Bang & 1968 & Chitty Chitty Bang Bang & Tschitti Tschitti Bäng Bäng \\
\hline The Party & 1968 & Zabava & Der Partyschreck \\
\hline Hang 'Em High & 1968 & Objesite ga bez milosti & Hängt ihn höher \\
\hline The Graduate & 1967 & Diplomac & Die Reifeprüfung \\
\hline The Jungle Book & 1967 & Knjiga o džungli & Das Dschungelbuch \\
\hline Cool Hand Luke & 1967 & Hladnokrvni kažnjenik & Der Unbeugsame \\
\hline You Only Live Twice & 1967 & Samo dvaput se živi & $\begin{array}{l}\text { James Bond } 007 \text { - Man lebt nur } \\
\text { zweimal }\end{array}$ \\
\hline The Dirty Dozen & 1967 & 12 žigosanih & Das dreckige Dutzend \\
\hline In the Heat of the Night & 1967 & U vrelini noći & In der Hitze der Nacht \\
\hline The Producers & 1967 & Producenti & Frühling für Hitler \\
\hline Who's Afraid of Virginia Woolf? & 1966 & Tko se boji Virginije Woolf? & Wer hat Angst vor Virginia Woolf? \\
\hline Blowup & 1966 & Povećanje & BlowUp - Ekstaze '67 \\
\hline How the Grinch Stole Christmas! & 1966 & Kako je Grinch ukrao Božić! & Die gestohlenen Weihnachtsgeschenke \\
\hline Manos: The Hands of Fate & 1966 & & Manos: The Hands of Fate \\
\hline A Man for All Seasons & 1966 & Čovjek za sva vremena & Ein Mann zu jeder Jahreszeit \\
\hline
\end{tabular}




\begin{tabular}{|c|c|c|c|}
\hline The Sound of Music & 1965 & Moje pjesme, moji snovi & Meine Lieder, meine Träume \\
\hline Thunderball & 1965 & Operacija Grom & James Bond 007 - Feuerball \\
\hline Repulsion & 1965 & Odvratnost & Ekel \\
\hline A Charlie Brown Christmas & 1965 & Božić Charlieja Browna & Die Peanuts - Fröhliche Weihnachten \\
\hline The Flight of the Phoenix & 1965 & Feniksov let & Der Flug des Phönix \\
\hline Help! & 1965 & U pomoć! & Hi-Hi-Hilfe! \\
\hline $\begin{array}{l}\text { Dr. Strangelove or: How I Learned to } \\
\text { Stop Worrying and Love the Bomb }\end{array}$ & 1964 & $\begin{array}{l}\text { Dr. Strangelove ili: Kako sam naučio ne } \\
\text { brinuti i zavolio bombu }\end{array}$ & $\begin{array}{l}\text { Dr. Seltsam, oder wie ich lernte, die } \\
\text { Bombe zu lieben }\end{array}$ \\
\hline My Fair Lady & 1964 & Moja draga lady & My Fair Lady \\
\hline A Hard Day's Night & 1964 & Noć nakon teškog dana & Yeah, Yeah, Yeah \\
\hline A Shot in the Dark & 1964 & Pink Panther: Pucanj u tami & Ein Schuß im Dunkeln \\
\hline Rudolph, the Red-Nosed Reindeer & 1964 & Rudolf, sob crvenog nosa & Rudolph mit der roten Nase \\
\hline The Great Escape & 1963 & Veliki bijeg & Gesprengte Ketten \\
\hline The Birds & 1963 & Ptice & Die Vögel \\
\hline From Russia with Love & 1963 & Iz Rusije s ljubavlju & $\begin{array}{l}\text { James Bond } 007 \text { - Liebesgrüße aus } \\
\text { Moskau }\end{array}$ \\
\hline The Sword in the Stone & 1963 & Mač u kamenu & Die Hexe und der Zauberer \\
\hline Charade & 1963 & Šarada & Charade \\
\hline The Pink Panther & 1963 & Pink Panther & Der rosarote Panther \\
\hline It's a Mad Mad Mad Mad World & 1963 & Svijet je poludio & Eine total, total verrückte Welt \\
\hline The Haunting & 1963 & Kuća duhova & Bis das Blut gefriert \\
\hline To Kill a Mockingbird & 1962 & Ubiti pticu rugalicu & Wer die Nachtigall stört \\
\hline Lawrence of Arabia & 1962 & Lawrence od Arabije & Lawrence von Arabien \\
\hline The Manchurian Candidate & 1962 & Mandžurijski kandidat & Botschafter der Angst \\
\hline The Man Who Shot Liberty Valance & 1962 & Čovjek koji je ubio Liberty Valancea & Der Mann, der Liberty Valance erschoß \\
\hline The Longest Day & 1962 & Najduži dan & Der Längste Tag \\
\hline What Ever Happened to Baby Jane? & 1962 & Sto se dogodilo s Baby Jane? & Was geschah wirklich mit Baby Jane? \\
\hline Breakfast at Tiffany's & 1961 & Doručak kod Tiffanyja & Frühstück bei Tiffany \\
\hline One Hundred and One Dalmatians & 1961 & 101 Dalmatinac & 101 Dalmatiner \\
\hline West Side Story & 1961 & Priča sa zapadne strane & West Side Story \\
\hline The Hustler & 1961 & Hazarder & Haie der Großstadt \\
\hline Judgment at Nuremberg & 1961 & Suđenje u Nürnbergu & Das Urteil von Nürnberg \\
\hline The Guns of Navarone & 1961 & Topovi s Navaronea & Die Kanonen von Navarone \\
\hline The Innocents & 1961 & Nevini & Schloß des Schreckens \\
\hline The Apartment & 1960 & Apartman & Das Appartement \\
\hline The Magnificent Seven & 1960 & Sedmorica veličanstvenih & Die glorreichen Sieben \\
\hline The Time Machine & 1960 & Vremenski stroj & Die Zeitmaschine \\
\hline Peeping Tom & 1960 & Voajer & Augen der Angst \\
\hline Nort by Northwest & 1959 & Sjever-sjeverozapad & Der unsichtbare Dritte \\
\hline Some Like It Hot & 1959 & Neki to vole vruće & Manche mögen's heiß \\
\hline Sleeping Beauty & 1959 & Trnoružica & Dornröschen \\
\hline
\end{tabular}




\begin{tabular}{|c|c|c|c|}
\hline Anatomy of a Murder & 1959 & Anatomija jednog ubojstva & Anatomie eines Morders \\
\hline Plan 9 from Outer Spce & 1959 & Plan 9 iz vanjskog svemira & Plan 9 aus dem Weltall \\
\hline House on Haunted Hill & 1959 & Kuća straha & Das Haus auf dem Geisterhügel \\
\hline Vertigo & 1958 & Vrtoglavica & Vertigo - Aus dem Reich der Toten \\
\hline Touch of Evil & 1958 & Dodir zla & Im Zeichen des Bösen \\
\hline Cat on a Hot Tin Roof & 1958 & Mačka na vrućem limenom krovu & Die Katze auf dem heißen Blechdach \\
\hline The Blob & 1958 & Gruda & Blob - Schrecken ohne Namen \\
\hline The Fly & 1958 & Muha & Die Fliege \\
\hline 12 Angry Men & 1957 & 12 gnjevnih ljudi & Die zwölf Geschworenen \\
\hline The Bridge on the River Kwai & 1957 & Most na rijeci Kwai & Die Brücke am Kwei \\
\hline Paths of Glory & 1957 & Staze slave & Wege zum Ruhm \\
\hline Witness for the Prosecution & 1957 & Svjedok optužbe & Zeugin der Klage \\
\hline An Affair to Remember & 1957 & Nešto za sjećanje & Die große Liebe meines Lebens \\
\hline Sweet Smell of Success & 1957 & Slatki miris uspjeha & Dein Schicksal in meiner Hand \\
\hline The Killing & 1956 & Uzaludna pljačka & Die Rechnung ging nicht auf \\
\hline The Searchers & 1956 & Tragači & Der schwarze Falke \\
\hline The Ten Commandments & 1956 & Deset zapovijedi & Die zehn Gebote \\
\hline The Man Who Knew Too Much & 1956 & Čovjek koji je previše znao & Der Mann, der zuviel wusste \\
\hline Invasion of the Body Snatchers & 1956 & Invazija tjelokradica & $\begin{array}{l}\text { Die Demonischen, auch: Invasion der } \\
\text { Körperfresser }\end{array}$ \\
\hline Forbidden Planet & 1956 & Zabranjen planet & Alarm im Weltall \\
\hline Giant & 1956 & Div & Giganten \\
\hline The King and I & 1956 & Kralj I ja & Der König und ich \\
\hline The Wrong Man & 1956 & Krivo optužen ili Nevino osuđen & Der falsche Mann \\
\hline Around the World in Eighty Days & 1956 & Put oko svijeta za 80 dana & In 80 Tagen um die Welt \\
\hline Lady and the Tramp & 1955 & Dama I skitnica & Susi und Strolch \\
\hline The Night of the Hunter & 1955 & Noć lovca & Die Nacht des Jägers \\
\hline Rebel Without a Cause & 1955 & Buntovnik bez razloga & ...denn sie wissen nicht, was sie tun \\
\hline To Catch a Thief & 1955 & Uhvatite lopova & Über den Dächern von Nizza \\
\hline East of Eden & 1955 & Istočno od raja & Jenseits von Eden \\
\hline The Seven Year Itch & 1955 & Sedma godina vjernosti & Das verflixte 7 . Jahr \\
\hline The Trouble with Harry & 1955 & Nevolje s Harryjem & Immer Ärger mit Harry \\
\hline The Ladykillers & 1955 & Gangsterska petorka & Ladykillers \\
\hline Rear Window & 1954 & Prozor u dvorište & Das Fenster zum Hof \\
\hline Dial M for Murder & 1954 & Nazovi M radi ubojstva & Bei Anruf Mord \\
\hline On the Waterfront & 1954 & Na dokovima New Yorka & Die Faust im Nacken \\
\hline 20,000 Leagues Under the Sea & 1954 & 20000 milja pod morem & 20000 Meilen unter dem Meer \\
\hline White Christmas & 1954 & Bijeli Božić & Weiße Weihnachten \\
\hline The Caine Mutiny & 1954 & Pobuna na brodu Caine & Die Caine war ihr Schicksal \\
\hline Roman Holiday & 1953 & Praznik u Rimu & Ein Herz und eine Krone \\
\hline
\end{tabular}




\begin{tabular}{|c|c|c|c|}
\hline Stalag 17 & 1953 & Stalag 17 & Stalag 17 \\
\hline From Here to Eternity & 1953 & Odavde od vječnosti & Verdammt in alle Ewigkeit \\
\hline The War of the Worlds & 1953 & Rat svjetova & Kampf der Welten \\
\hline Gentlemen Prefer Blondes & 1953 & Muškarci više vole plavuše & Blondinen bevorzugt \\
\hline The Big Heat & 1953 & Velika žega & Heiße eisen \\
\hline Singin' in the Rain & 1952 & Pjevajmo na kiši & Du sollst mein Glücksstern sein \\
\hline High Noon & 1952 & Točno u podne & Zwölf Uhr Mittags \\
\hline The Quiet Man & 1952 & Miran čovjek & Der Sieger \\
\hline Limelight & 1952 & Svjetla pozornice & Rampenlicht \\
\hline Monkey Business & 1952 & Majmunska posla & Liebling, ich werde jünger \\
\hline The Bad and the Beautiful & 1952 & Grad iluzija & Stadt der Illusionen \\
\hline The Greatest Show on Earth & 1952 & Najveća predstava na svijetu & Die größte Schau der Welt \\
\hline Strangers on a Train & 1951 & Nepoznati iz Nord Expressa & Der Fremde im Zug \\
\hline A Streetcar Named Desire & 1951 & Tramvaj zvan čežnja & Endstation Sehnsucht \\
\hline The Day the Earth Stood Still & 1951 & Dan kad je zemlja stala & Der Tag, an dem die Erde stillstand \\
\hline The African Queen & 1951 & Afrička kraljica & African Queen \\
\hline Ace in the Hole & 1951 & As u rukavu & Reporter des Satans \\
\hline The Thing from Another World & 1951 & Stvar & Das Ding aus einer anderen Welt \\
\hline A Place in the Sun & 1951 & Mjesto pod suncem & Ein Platz an der Sonne \\
\hline All About Eve & 1950 & Sve o Evi & Alles über Eva \\
\hline Twelve O'Clock Higjh & 1949 & Polijetanje usred dana & Der Kommandeur \\
\hline All the King's Men & 1949 & Sve kraljevi ljudi & Der Mann, der herrschen wollte \\
\hline The Heiress & 1949 & Nasljednica & Die Erbin \\
\hline Rope & 1948 & Uže & Cocktail für eine Leiche \\
\hline The Treasure of the Sierra Madre & 1948 & Blago Sierra Madre & Der Schatz der Sierra Madre \\
\hline The Red Shoes & 1948 & Crvene cipelice & Die roten Schuhe \\
\hline $\begin{array}{l}\text { Bud Abbott Lou Costello Meet } \\
\text { Frankenstein }\end{array}$ & 1948 & Abbott I Costello susreću Frankensteina & $\begin{array}{l}\text { Abbott und Costello treffen } \\
\text { Frankenstein }\end{array}$ \\
\hline The Naked City & 1948 & Goli grad & Stadt ohne Maske \\
\hline Miracle on 34th Street & 1947 & Čudo u 34. ulici & Das Wunder von Manhattan \\
\hline Out of the Past & 1947 & Iz prošlosti & Goldenes Gift \\
\hline The Lady from Shanghai & 1947 & Dama iz Šangaja & Die Lady von Schanghai \\
\hline Black Narcissus & 1947 & Crni narcis & Die schwarze Narzisse \\
\hline Dark Passage & 1947 & Mračni prolaz & Die schwarze Natter \\
\hline The Ghost and Mrs. Muir & 1947 & Duh I gospođa Mjur & Ein Gespenst auf Freiersfüßen \\
\hline Gentlemen's Agreement & 1947 & Đentlmenski sporazum & Tabu der Gerechten \\
\hline The Bishop's Wife & 1947 & Biskupova žena & Jede Frau braucht einen Engel \\
\hline The Paradine Case & 1947 & Slučaj Paradine & Der Fall Paradin \\
\hline It's a Wonderful Life & 1946 & Divan život & Ist das Leben nicht schön \\
\hline Notorious & 1946 & Ozloglašena & Berüchtigt \\
\hline
\end{tabular}




\begin{tabular}{|c|c|c|c|}
\hline The Big Sleep & 1946 & Duboki san & Tote schlafen fest \\
\hline The Best Years of Our Lives & 1946 & Najbolje godine našega života & Die besten Jahre unseres Lebens \\
\hline Great Expectations & 1946 & Velika išćekivanja & Geheimnisvolle Erbschaft \\
\hline My Darling Clementine & 1946 & Moja draga Klementina & Faustrecht der Prärie \\
\hline The Postman Always Rings Twice & 1946 & Poštar uvijek zvoni dvaput & Im Netz der Leidenschaft \\
\hline The Killers & 1946 & Ubojice & Rache der Unterwelt \\
\hline Spellbound & 1945 & Začarana (isto: Opsjednut) & Ich kämpfe um dich \\
\hline Brief Encounter & 1945 & Kratak susret & Begegnung \\
\hline The Lost Weekend & 1945 & Izgubljeni vikend & Das verlorene Wochenende \\
\hline Detour & 1945 & Skretanja (isto: Zaobilaznica) & Umleitung \\
\hline And Then There Were None & 1945 & I ne osta nijedan & Das letzte Wochenende \\
\hline The Picture of Dorian Gray & 1945 & Slika Dorijana Grayja & Das Bildnis des Dorian Gray \\
\hline Double Indemnity & 1944 & Dvostruka obmana & Frau ohne Gewissen \\
\hline Arsenic and Old Lace & 1944 & Arsen I stare čipke & Arsen und Spitzenhäubchen \\
\hline To Have and Have Not & 1944 & Imati I nemati & Haben und Nichthaben \\
\hline Lifeboat & 1944 & Čamac za spašavanje & Das Rettungsboot \\
\hline Gaslight & 1944 & Plinsko svijetlo & Das Haus der Lady Alquist \\
\hline Meet Me in St. Louis & 1944 & Srest ćemo se u St. Louisu & Meet me in St. Louis \\
\hline The Woman in the Window & 1944 & Žena u izlogu & Gefährliche Begegnungen \\
\hline Murder, My Sweet & 1944 & Zbogom ljepotice & $\begin{array}{l}\text { Mord, meine Liebling, auch: Leb wohl, } \\
\text { Liebling }\end{array}$ \\
\hline The Three Caballeros & 1944 & Tri Kabaljerosa & $\begin{array}{l}\text { Drei Caballeros (ursprünglich: Donald } \\
\text { erobert Mexiko) }\end{array}$ \\
\hline Shadow of a Doubt & 1943 & Sjenka sumnje & Im Schatten des Zweifels \\
\hline The Ox-Bow Incident & 1943 & Omča za vješanje & Ritt zum Ox -Bow \\
\hline The Life and Death of Colonel Blimp & 1943 & Život I smrt pukovnika Blimpa & Leben und Sterben des Colonel Blimp \\
\hline I Walked with a Zombie & 1943 & Šetala sam se uz zombija & Ich folgte einem Zombie \\
\hline Heaven Can Wait & 1943 & Nebo ne može čekati & Ein himmlischer Sünder \\
\hline For Whom the Bell Tolls & 1943 & Kome zvono zvoni & Wem die Stunde schlägt \\
\hline To $\mathrm{Be}$ or Not to $\mathrm{Be}$ & 1942 & Biti ili ne biti & Sein oder Nichtsein \\
\hline Saboteur & 1942 & Saboter & Saboteure \\
\hline The Magnificent Ambersons & 1942 & Veličanstveni Ambersonovi & Der Glanz des Hauses Amberson \\
\hline Cat People & 1942 & Ljudi mačke & Katzenmenschen \\
\hline Now, Voyager & 1942 & Na raskršću & Reise aus der Vergangenheit \\
\hline Citizen Kane & 1941 & Građanin Kane & Bürger Kane \\
\hline The Maltese Falcon & 1941 & Malteški sokol & Die Spur des Falken \\
\hline Suspicion & 1941 & Sumnja & Verdacht \\
\hline Sullivan's Travels & 1941 & Sullivanovo putovanje & Sullivans Reisen \\
\hline The Wolf Man & 1941 & Vukodlak & Der Wolfmensch \\
\hline How Green Was My Valley & 1941 & Kako je bila zelena moja dolina & Schlagende Wetter \\
\hline The Lady Eve & 1941 & Lady Eve & Die Falschspielerin \\
\hline
\end{tabular}




\begin{tabular}{|c|c|c|c|}
\hline Sergeant York & 1941 & Narednik York & Sergeant York \\
\hline High Sierra & 1941 & Visoka Sierra & Entscheidung in der Sierra \\
\hline The Great Dictator & 1940 & Veliki diktator & Der große Diktator \\
\hline Fantasia & 1940 & Fantazija & Fantasia \\
\hline The Grapes of Wrath & 1940 & Plodovi gnjeva & Früchte des Zorns \\
\hline The Philadelphia Story & 1940 & Philadelphijska priča & Die Nacht vor der Hochzeit \\
\hline His Girl Friday & 1940 & Njegova djevojka petko & Sein Mädchen für besondere Fälle \\
\hline The Shop Around the Corner & 1940 & Trgovina iza ugla & Rendezvous nach Ladenschluss \\
\hline Foreign Correspondent & 1940 & Strani dopisnik & Der Auslandskorrespondent \\
\hline The Thief of Bagdad & 1940 & Bagdadski lopov & Der Dieb von Bagdad \\
\hline The Wizard of $\mathrm{Oz}$ & 1939 & Čarobnjak iz Oza & Der Zauberer von $\mathrm{Oz}$ \\
\hline Gone with the Wind & 1939 & Zameo ih vjetar & Vom Winde verweht \\
\hline Mr. Smith Goes to Washington & 1939 & Gospodin Smith ide u Washington & Mr. Smith geht nach Washington \\
\hline Stagecoach & 1939 & Poštanska kočija & Ringo \\
\hline Wuthering Heights & 1939 & Orkanski visovi & Sturmhöhe \\
\hline The Women & 1939 & Žene & Die Frauen \\
\hline The Roaring Twenties & 1939 & Burne dvadesete & Die wilden Zwanziger \\
\hline Only Angels Have Wings & 1939 & Samo anđeli imaju krila & S.O.S. Feuer an Bord \\
\hline Bringing Up Baby & 1938 & Silom dadilja & Leoparden küsst man nicht \\
\hline The Adventures of Robin Hood & 1938 & Pustolovine Robina Hooda & Robin Hood, König der Vagabunden \\
\hline The Lady Vanishes & 1938 & Dama koja nestaje & Eine Dame verschwindet \\
\hline You Can't Take It with You & 1938 & U grob ništa ne nosiš & Lebenskünstler \\
\hline Angels with Dirty Faces & 1938 & Anđeli garava lica & $\begin{array}{l}\text { Chicaco -Engel mit schmutzigen } \\
\text { Gesichtern }\end{array}$ \\
\hline Holiday & 1938 & Praznik & Die Schwester der Braut \\
\hline Snow White and the Seven Dwarfs & 1937 & Snjeguljica i sedam patuljaka & Schneewittchen und die sieben Zwerge \\
\hline The Awful Truth & 1937 & Strašna istina & Die schreckliche Wahrheit \\
\hline A Day at the Races & 1937 & Dan na utrkama (isto: Dan na trkama) & $\begin{array}{l}\text { Die Marx Brothers: Ein Tag beim } \\
\text { Rennen }\end{array}$ \\
\hline Lost Horizon & 1937 & Izgubljeni horizont & In den Fesseln von Shangri - La \\
\hline Captains Courageous & 1937 & Kapetan Hrabrosti & Manuel \\
\hline Young and Innocent & 1937 & Mladi i nevini & Jung und unschuldig \\
\hline Stage Door & 1937 & Ulaz na pozornicu & Bühneneingang \\
\hline Way Out West & 1937 & Stanlio i Olio na Divljem zapadu & $\begin{array}{l}\text { Laurel und Hardy: Zwei ritten nach } \\
\text { Texas }\end{array}$ \\
\hline A Star Is Born & 1937 & Zvijezda je rođena & Ein Stern geht auf \\
\hline Modern Times & 1936 & Moderna vremena & Moderne Zeiten \\
\hline My Man Godfrey & 1936 & Moj čovjek Godfrey & Mein Mann Godfrey \\
\hline Mr. Deeds Goes to Town & 1936 & Gospodin Deeds ide u grad & Mr. Deeds geht in die Stadt \\
\hline Sabotage & 1936 & Sabotaža & Sabotage \\
\hline The Petrified Forest & 1936 & Okamenjena šuma & Der versteinerte Wald \\
\hline
\end{tabular}




\begin{tabular}{|c|c|c|c|}
\hline Swing Time & 1936 & Doba swinga & Swing Time \\
\hline Fury & 1936 & Bijes & Blinde Wut \\
\hline After the Thin Man & 1936 & Nakon Mršavka & Dünner Mann, 2. Fall \\
\hline Tell Your Children & 1936 & Ludilo trave & Reefer Madness \\
\hline Dodsworth & 1936 & Dodsworth & Zeit der Liebe, Zeit des Abschieds \\
\hline The 39 Steps & 1935 & 39 stepenica & Die 39 Stufen \\
\hline Bride of Frankenstein & 1935 & Frankensteinova nevjesta & Frankensteins Braut \\
\hline A Night at the Opera & 1935 & Noć u operi & Skandal in der Oper \\
\hline Mutiny on the Bounty & 1935 & Pobuna u Bountyju & Meuterei auf der Bounty \\
\hline Top Hat & 1935 & Cilindar & Ich tanz' mich in dein Herz hinein \\
\hline Captain Blood & 1935 & Captain Blood & Unter Piratenflagge \\
\hline The Informer & 1935 & Potkazivač & Der Verräter \\
\hline A Tale of Two Cities & 1935 & Priča o dva grada & Flucht aus Paris \\
\hline It Happened One Night & 1934 & Dogodilo se jedne noći & Es geschah in einer Nacht \\
\hline The Thin Man & 1934 & Mršavko & Der dünne Mann \\
\hline The Man Who Knew Too Much & 1934 & Čovjek koji je previše znao & Der Mann, der zuviel wusste \\
\hline The Black Cat & 1934 & Crna mačka & Die schwarze Katze \\
\hline The Gay Divorcee & 1934 & $\begin{array}{l}\text { Vesela rastava (isto: Vesela } \\
\text { razvedenica) }\end{array}$ & Tanz mit mir! \\
\hline Twentieth Century & 1934 & Dvadeseto stoljeće & Napoleon vom Broadway \\
\hline Babes in Toyland & 1934 & & Laurel und Hardy: Rache ist süß \\
\hline Of Human Bondage & 1934 & Ljudski okovi & Of Human Bondage \\
\hline The Scarlet Empress & 1934 & Grimizna carica & Die scharlachrote Kaiserin \\
\hline Duck Soup & 1933 & Pačja juha & Die Marx Brothers im Krieg \\
\hline The Invisible Man & 1933 & Nevidljivi čovjek & Der Unsichtbare \\
\hline Dinner at Eight & 1933 & Večera u osam & Dinner um acht \\
\hline Sons of the Desert & 1933 & Sinovi pustinje & Laurel und Hardy: Die Wüstensöhne \\
\hline Queen Christina & 1933 & Kraljica Kristina & Königin Christine \\
\hline Gold Diggers of 1933 & 1933 & Lov na sreću & Goldgräber von 1933 \\
\hline Freaks & 1932 & Nakaze & Freaks \\
\hline Scarface & 1932 & Lice s ožiljkom & Narbengesicht \\
\hline The Mummy & 1932 & Mumija & Die Mumie \\
\hline Trouble in Paradise & 1932 & Nevolje u raju & Ärger im Paradies \\
\hline Horse Feathers & 1932 & Konjsko perje & Blühender Blödsinn \\
\hline I Am a Fugitive from a Chain Gang & 1932 & Ja sam bjegunac iz Chain ganga & Jagd auf James A. \\
\hline The Most Dangerous Game & 1932 & The Most Dangerous Game & Graf Zaroff - Genie des Bösen \\
\hline White Zombie & 1932 & White Zombie & The White Zombie \\
\hline City Lights & 1931 & Svjetla velegrada & Lichter der Großstadt \\
\hline The Public Enemy & 1931 & Državni neprijatelj & Der öffentliche Feind \\
\hline Dr. Jekyll and Mr. Hyde & 1931 & Dr. Jekyll i Mr. Hyde & Dr. Jekyll und Mr. Hyde \\
\hline
\end{tabular}




\begin{tabular}{|c|c|c|c|}
\hline Monkey Business & 1931 & Majmunska posla & Die Marx Brothers auf See \\
\hline Little Caesar & 1931 & Mali Cezar & Der kleine Cäsar \\
\hline Tabu: A Story of the South Seas & 1931 & Tabu & Tabu \\
\hline All Quiet on the Western Front & 1930 & Na zapadu ništa novo & Im Westen nichts Neues \\
\hline Animal Crackers & 1930 & Animal Crackers & Animal Crackers \\
\hline Murder! & 1930 & Umorstvo & Mord - Sir John greift ein! \\
\hline Hell's Angels & 1930 & Pakleni anđeli & Höllenflieger \\
\hline The Big Trail & 1930 & Veliki put & Der große Treck \\
\hline Blackmail & 1929 & Ucjena & Erpressung \\
\hline The Broadway Melody & 1929 & Brodvejska melodija & The Broadway Melody \\
\hline The Skeleton Dance & 1929 & Skeletni ples? & Tanz der Skelette \\
\hline Queen Kelly & 1929 & Kraljica Kelly & Queen Kelly \\
\hline Big Business & 1929 & Veliki posao & Laurel und Hardy: Das große Geschäft \\
\hline The Circus & 1928 & Cirkus & Der Zirkus \\
\hline Steamboat Bill, Jr. & 1928 & Steamboat Bill, Jr. & $\begin{array}{l}\text { Steamboat Bill, Jr. (Alternative: } \\
\text { Stürmische Zeiten) }\end{array}$ \\
\hline The Cameraman & 1928 & Kameraman & Der Kameramann \\
\hline The Crowd & 1928 & Gomila & Ein Mensch der Masse \\
\hline Steamboat Willie & 1928 & Parobrod Willy & Steamboat Willie \\
\hline The Wind & 1928 & Vjetar & Der Wind \\
\hline The Man Who Laughs & 1928 & Čovjek koji se smije? & Der Mann, der lacht \\
\hline Show People & 1928 & Show People & Es tut sich was in Hollywood \\
\hline Sunrise: A Song of Two Humans & 1927 & $\begin{array}{l}\text { Izlazak sunca - Pjesma o dva ljudska } \\
\text { bića }\end{array}$ & $\begin{array}{l}\text { Sonnenaufgang - Lied von zwei } \\
\text { Menschen }\end{array}$ \\
\hline Wings & 1927 & Krila & Wings \\
\hline The Lodger: A Story of the London Fog & 1927 & Stanar: Priča o londonskoj magli & Der Mieter \\
\hline The Jazz Singer & 1927 & Pjevač jazza & Der Jazzsänger \\
\hline The Unknown & 1927 & Nepoznati & The Unknown - Der Unbekannte \\
\hline College & 1927 & Koledž & Der Musterschüler \\
\hline The Kid Brother & 1926 & The Kid Brother (Mlađi brat) & Der kleine Bruder \\
\hline The General & 1926 & General & Der General \\
\hline Flesh and the Devil & 1926 & Put I đavo & Es war \\
\hline Battling Butler & 1926 & Buster boksački prvak & Der Killer von Alabama \\
\hline The Son of the Sheik & 1926 & The Son of the Sheik & Der Sohn des Scheichs \\
\hline The Black Pirate & 1925 & & Der Seeräuber \\
\hline The Gold Rush & 1925 & Potjera za zlatom & Der Goldrausch \\
\hline The Phantom of the Opera & 1925 & Fantom opere & Das Phantom der Oper \\
\hline Seven Chances & 1925 & Sedam sreća & Sieben Chancen \\
\hline Ben-Hur: A Tale of the Christ & 1925 & & Ben Hur \\
\hline The Big Parade & 1925 & Velika parada & Die große Parade \\
\hline The Freshman & 1925 & Brucoš & Der Sportstudent \\
\hline
\end{tabular}




\begin{tabular}{|c|c|c|c|}
\hline The Lost World & 1925 & Izgubljeni svijet & Die verlorene Welt \\
\hline Go West & 1924 & Na zapad & Der Cowboy \\
\hline Sherlock Jr. & 1924 & Sherlock Jr. & Sherlock jr. \\
\hline Greed & 1924 & Pohlepa & Gier \\
\hline The Navigator & 1924 & Navigator & Der Navigator \\
\hline The Thief of Bagdad & 1924 & Bagdadski lopov & Der Dieb von Bagdad \\
\hline Girl Shy & 1924 & Girl Shy & Mädchenscheu \\
\hline He Who Gets Slapped & 1923 & Onaj kojega su tresnuli & Der Mann, der die Ohrfeigen bekam \\
\hline Safety Last! & 1923 & Napokon spas! & Ausgerechnet Wolkenkratzer! \\
\hline Our Hospitality & 1923 & Naše gostoprimstvo & Verflixte Gastfreundschaft \\
\hline The Hunchback of Notre Dame & 1923 & Zvonar crkve Notre - Dame & Der Glöckner von Notre Dame \\
\hline A Woman of Paris: A Drama of Fate & 1923 & Parižanka & Die Nächte einer schönen Frau \\
\hline The Pilgrim & 1923 & Hodočasnik & Der Pilger \\
\hline Three Ages & 1923 & Tri povijesna doba & Drei Zeitalter \\
\hline The Balloonatic & 1923 & Plin smijavac & \\
\hline The Love Nest & 1923 & & Das Liebesnest \\
\hline The Ten Commandments & 1927 & Deset zapovijedi & Die zehn Gebote \\
\hline
\end{tabular}


SPECIFIČNI KORPUS

\begin{tabular}{|c|c|c|c|}
\hline ORIGINALNI NASLOV & $\begin{array}{c}\text { GODI } \\
\text { NA }\end{array}$ & NJEMAČKI PRIJEVOD & HRVATSKI PRIJEVOD \\
\hline (500) Days of Summer & 2009 & (500) Days of Summer & (500) dana ljubavi \\
\hline 100 Feet & 2008 & 100 Feet & 100 stopa \\
\hline $11-11-11$ & 2011 & 11-11-11 - Das Tor zur Hölle & $11-11-11$ \\
\hline 12 Angry Men & 1957 & Die zwölf Geschworenen & 12 ljutih muškaraca \\
\hline 12 Monkeys & 1995 & 12 Monkeys & 12 majmuna \\
\hline 12 Years a Slave & 2013 & 12 Years a Slave & 12 godina ropstva \\
\hline 127 Hours & 2010 & 127 Hours & 127 sati \\
\hline 17 Again & 2009 & 17 Again - Back to High School & Ponovno 17 \\
\hline 21 Jump Street & 2012 & 21 Jump Street & 21 Jump Street \\
\hline 22 Jump Street & 2014 & 22 Jump Street & 22 Jump Street \\
\hline $247^{\circ} \mathrm{F}$ & 2011 & 247 Grad Fahrenheit - Todesfalle Sauna & \\
\hline 27 Dresses & 2008 & 27 Dresses & Zauvijek djeveruša, nikad nevjesta \\
\hline 50 First Dates & 2004 & 50 erste Dates & 50 prvih poljubaca \\
\hline $50 / 50$ & 2011 & 50/50 - Freunde fürs (Über)Leben & $50 / 50$ \\
\hline A Beautiful Mind & 2001 & A Beautiful Mind - Genie und Wahnsinn & Genijalni um \\
\hline A Few Best Men & 2011 & Die Trauzeugen & Mamurni kumovi \\
\hline A Haunted House & 2013 & Ghost Movie & Paranenormalna aktivnost \\
\hline A LEGOBrickumentary & 2014 & & \\
\hline A Million Ways to Die in the West & 2014 & A Million Ways to Die in the West & Tko preživi, pričat će \\
\hline A Most Wanted Man & 2014 & A Most Wanted Man & Najtraženiji čovjek \\
\hline A Very English Genius & 2002 & & \\
\hline A Walk in the Woods & 2015 & Picknick mit Bären & \\
\hline About Time & 2013 & Alles eine Frage der Zeit & Pravi trenutak \\
\hline Accepted & 2006 & S.H.I.T. - Die Highschool GmbH & Fakultet za gubitnike \\
\hline Afflicted & 2013 & & Unesrećen \\
\hline
\end{tabular}




\begin{tabular}{|c|c|c|c|}
\hline After Sex & 2007 & Sexgeflüster & Nakon seksa \\
\hline Aftershock & 2012 & Aftershock - Die Hölle nach dem Beben & Aftershock \\
\hline Airplane vs. Volcano & 2014 & Airplane vs. Volcano & Avion protiv vulkana \\
\hline $\begin{array}{l}\text { Alexander, and the Terrible, Horrible, No Good, } \\
\text { Very Bad Day }\end{array}$ & 2014 & Die Coopers - Schlimmer geht immer & $\begin{array}{l}\text { Alexander i grozan, užasan, loš, vrlo } \\
\text { loš dan }\end{array}$ \\
\hline Alien & 1979 & Alien - Das unheimliche Wesen aus einer fremden Welt & Alien: Osmi putnik \\
\hline Alien 3 & 1992 & Alien 3 & Alien 3 \\
\hline Alien: Resurrection & 1997 & Alien - Die Wiedergeburt & Alien: Uskrsnuće \\
\hline Aliens & 1986 & Aliens - Die Rückkehr & Alien 2 \\
\hline All About Steve & 2009 & Verrückt nach Steve & Sve o Steveu \\
\hline Almost Famous & 2000 & Almost Famous - Fast berühmt & Korak do slave \\
\hline Aloha & 2015 & Aloha - Die Chance auf Glück & Aloha \\
\hline Along Came Polly & 2004 & ...und dann kam Polly & Napokon Polly \\
\hline American Hustle & 2013 & American Hustle & Američki varalice \\
\hline American Pie & 1999 & American Pie - Wie ein heißer Apfelkuchen & Američka pita \\
\hline American Pie 2 & 2001 & American Pie 2 & Američka pita 2 \\
\hline American Psycho & 2000 & American Psycho & Američki psiho \\
\hline American Reunion & 2012 & American Pie: Das Klassentreffen & Američka pita: Okupljanje \\
\hline American Sniper & 2014 & American Sniper & Američki snajper \\
\hline American Ultra & 2015 & American Ultra & American Ultra \\
\hline American Wedding & 2003 & American Pie - Jetzt wird geheiratet & Američka pita 3: Vjenčanje \\
\hline Anatomy of a Murder & 1959 & Anatomie eines Mordes & $\begin{array}{l}\text { Anatomija jednog umorstva } \\
\text { Anatomija jednog ubojstva }\end{array}$ \\
\hline Anchorman 2: The Legend Continues & 2013 & Anchorman - Die Legende kehrt zurück & Voditelj: Legenda se nastavlja \\
\hline Anchorman: The Legend of Ron Burgundy & 2004 & Anchorman - Die Legende von Ron Burgundy & Voditelj uzvraća udarac \\
\hline And Soon the Darkness & 2010 & $\begin{array}{l}\text { And Soon the Darkness } \\
\text { Mörderische Ferien (TV) }\end{array}$ & \\
\hline Angels \& Demons & 2009 & Illuminati & Anđeli i demoni \\
\hline Annabelle & 2014 & Annabelle & Annabelle \\
\hline Anonymous & 2011 & Anonymous & Nepoznati \\
\hline
\end{tabular}




\begin{tabular}{|c|c|c|c|}
\hline Antichrist & 2009 & Antichrist & Antikrist \\
\hline Ant-Man & 2015 & Ant-Man & Ant-Man \\
\hline Apollo 13 & 1995 & Apollo 13 & Apollo 13 \\
\hline Apollo 18 & 2011 & Apollo 18 & Apollo 18 \\
\hline Are We There Yet? & 2005 & Sind wir schon da? & Jesmo li stigli? \\
\hline Argo & 2012 & Argo & Argo \\
\hline Around the World in 80 Days & 2004 & In 80 Tagen um die Welt & Put oko svijeta u 80 dana \\
\hline As Above, So Below & 2014 & Katakomben & U mraku katakombe \\
\hline Ass Backwards & 2013 & Ass Backwards - Die Schönsten sind wir & $\begin{array}{l}\text { Nerazdvojne prijateljice } \\
\text { Tuapava i tupavija }\end{array}$ \\
\hline ATM & 2012 & ATM - Tödliche Falle & Bankomat \\
\hline Avengers: Age of Ultron & 2015 & Marvel's The Avengers 2: Age of Ultron & Osvetnici 2: Vladavina Ultrona \\
\hline Awake & 2007 & Awake & Budan \\
\hline Baby Mama & 2008 & Baby Mama & Rent-a-Mama \\
\hline Baby on Board & 2009 & Baby on Board & Stiže iznenađenje \\
\hline Bachelorette & 2012 & Die Hochzeit unserer dicksten Freundin & Djeveruše pod gasom \\
\hline Bad Teacher & 2011 & Bad Teacher & Zločesta učiteljica \\
\hline Bad Words & 2013 & Bad Words & Ružne riječi \\
\hline Beauty and the Beast & 1991 & Die Schöne und das Biest & Ljepotica i zvijer \\
\hline Before I Go to Sleep & 2014 & Ich. Darf. Nicht. Schlafen. & Prije nego što zaspim \\
\hline Begin Again & 2013 & Can a Song Save Your Life? & Pjesma koja ljubav znači \\
\hline Beginners & 2010 & Beginners & Početnici \\
\hline Better Living Through Chemistry & 2014 & Hauptsache, die Chemie stimmt & Plavuša na recept \\
\hline Big Hero 6 & 2014 & Baymax - Riesiges Robowabohu & Ekipa za 6 \\
\hline Billy Elliot & 2000 & Billy Elliot - I Will Dance & Billy Elliot \\
\hline Birdman or (The Unexpected Virtue of Ignorance) & 2014 & $\begin{array}{l}\text { Birdman oder (Die unverhoffte Macht der } \\
\text { Ahnungslosigkeit) }\end{array}$ & Birdman \\
\hline Black Death & 2010 & Black Death & Crna smrt \\
\hline Black Mass & 2015 & Black Mass & Crna misa \\
\hline Black Swan & 2010 & Black Swan & Crni labud \\
\hline Blackfish & 2013 & $\begin{array}{l}\text { Blackfish } \\
\text { Der Killerwal }\end{array}$ & Kit ubojica \\
\hline Blades of Glory & 2007 & Die Eisprinzen & Ledom do slave \\
\hline Blindness & 2008 & Die Stadt der Blinden & Sljepoća \\
\hline Blood Diamond & 2006 & Blood Diamond & Krvavi dijamant \\
\hline Blue Jasmine & 2013 & Blue Jasmine & Jasmine French \\
\hline
\end{tabular}




\begin{tabular}{|c|c|c|c|}
\hline Boogeyman & 2005 & Boogeyman - Der schwarze Mann & Tihi vrisak \\
\hline Book of Shadows: Blair Witch 2 & 2000 & Blair Witch 2 & Vještica iz Blaira 2 \\
\hline Boyhood & 2014 & Boyhood & Odrastanje \\
\hline Boys Don't Cry & 1999 & Boys Don't Cry & Dečki nikad ne plaču \\
\hline Brain Divided & 2013 & & \\
\hline Brave & 2012 & Merida - Legende der Highlands & Merida Hrabra \\
\hline Bride Wars & 2009 & Bride Wars - Beste Feindinnen & Rat među nevjestama \\
\hline Bridesmaids & 2011 & Brautalarm & Djeveruše \\
\hline Bull Durham & 1988 & Annies Männer & Bull Durham \\
\hline Buried & 2010 & Buried - Lebend begraben & Živ zakopan \\
\hline Burnt & 2015 & Im Rausch der Sterne & Paklena kuhinja \\
\hline But I'm a Cheerleader & 1999 & Weil ich ein Mädchen bin & \\
\hline Captain America: The First Avenger & 2011 & Captain America: The First Avenger & Kapetan Amerika: Prvi osvetnik \\
\hline Captain America: The Winter Soldier & 2014 & The Return of the First Avenger & Kapetan Amerika: Ratnik zime \\
\hline Captivity & 2007 & Captivity - Tödliches Spiel & Ćelija straha \\
\hline Carnage & 2011 & Der Gott des Gemetzels & Bračne svađe \\
\hline Carriers & 2009 & Carriers - Flucht vor der tödlichen Seuche & Epidemija \\
\hline Cartel Land & 2015 & & \\
\hline Case 39 & 2009 & Fall 39 & Slučaj 39 \\
\hline Casino Royale & 2006 & James Bond 007 - Casino Royale & Casino Royale \\
\hline Catacombs & 2007 & Catacombs - Unter der Erde lauert der Tod & Katakombe \\
\hline Catwoman & 2004 & Catwoman & Žena mačka \\
\hline Cave of Forgotten Dreams & 2010 & Die Höhle der vergessenen Träume & \\
\hline Changeling & 2008 & Der fremde Sohn & Zamjena \\
\hline Chappie & 2015 & Chappie & Chappie \\
\hline Charlie and the Chocolate Factory & 2005 & Charlie und die Schokoladenfabrik & Charlie i tvornica čokolade \\
\hline Cheaper by the Dozen & 2003 & Im Dutzend billiger & Popust na količinu \\
\hline Cheaper by the Dozen 2 & 2005 & Im Dutzend billiger 2: Zwei Väter drehen durch & Popust na količinu 2 \\
\hline Chef & 2014 & Kiss the Cook: So schmeckt das Leben & Glavni kuhar \\
\hline Chernobyl Diaries & 2012 & Chernobyl Diaries & Černobilski dnevnici \\
\hline Cinderella & 2015 & Cinderella & Pepeljuga \\
\hline Citizenfour & 2014 & Citizenfour & Citizenfour \\
\hline Cloudy with a Chance of Meatballs & 2009 & Wolkig mit Aussicht auf Fleischbällchen & Oblačno s ćuftama \\
\hline Contact & 1997 & Contact & Kontakt \\
\hline Contagion & 2011 & Contagion & Zaraza \\
\hline
\end{tabular}




\begin{tabular}{|c|c|c|c|}
\hline Crazy, Stupid, Love. & 2011 & Crazy, Stupid, Love. & Ta luda ljubav \\
\hline Creation & 2009 & Creation & Postanak \\
\hline Crimson Peak & 2015 & Crimson Peak & Crimson Peak \\
\hline Dallas Buyers Club & 2013 & Dallas Buyers Club & Dobri dileri iz Dallasa \\
\hline Danny Collins & 2015 & Manglehorn - Schlüssel zum Glück & Danny Collins \\
\hline Dante's Peak & 1997 & Dante's Peak & Danteov vrh \\
\hline Dark Skies & 2013 & Dark Skies - Sie sind unter uns & Zamračenje \\
\hline Date Night & 2010 & Date Night - Gangster für eine Nacht & Savršeni spoj \\
\hline Dawn of the Planet of the Apes & 2014 & Planet der Affen: Revolution & Planet majmuna: Revolucija \\
\hline Deliver Us from Evil & 2014 & Erlöse uns von dem Bösen & Izbavi nas od zla \\
\hline Delivery Man & 2013 & Der Lieferheld - Unverhofft kommt oft & Dostavljač \\
\hline Despicable Me & 2010 & Ich - Einfach unverbesserlich & Kako je Gru ukrao mjesec \\
\hline Despicable Me 2 & 2013 & Ich - Einfach unverbesserlich 2 & Gru na supertajnom zadatku \\
\hline Devil & 2010 & Devil: Fahrstuhl zur Hölle & Sotona \\
\hline Dirty Wars & 2013 & Schmutzige Kriege & Prljavi ratovi \\
\hline Disconnect & 2012 & Disconnect & Prekinuta veza \\
\hline District 9 & 2009 & District 9 & Distrikt 9 \\
\hline Disturbia & 2007 & Disturbia - Auch Killer haben Nachbarn & Paranoja \\
\hline Divergent & 2014 & Die Bestimmung - Divergent & Različita \\
\hline Django Unchained & 2012 & Django Unchained & Odbjegli Django \\
\hline Don Jon & 2013 & Don Jon - Was Frauen wollen und Männer brauchen & Don Jon \\
\hline Dorian Gray & 2009 & Das Bildnis des Dorian Gray & Dorian Gray \\
\hline Drillbit Taylor & 2008 & Drillbit Taylor - Ein Mann für alle Unfälle & Traži se bodyguard \\
\hline Drinking Buddies & 2013 & Drinking Buddies - Erwachsen werden ist schwer & Prijatelji po pivu \\
\hline E.T. the Extra-Terrestrial & 1982 & E.T. - Der Außerirdische & E.T. \\
\hline Eagle Eye & 2008 & Eagle Eye - Außer Kontrolle & Oko sokolovo \\
\hline Easy A & 2010 & Einfach zu haben & Cura na lošem glasu \\
\hline Edge of Tomorrow & 2014 & Edge of Tomorrow & Na rubu budućnosti \\
\hline Elf & 2003 & Buddy - Der Weihnachtself & Vilenjak \\
\hline Eliza Graves & 2014 & Stonehearst Asylum - Diese Mauern wirst du nie verlassen & Umobolnica na osami \\
\hline Elysium & 2013 & Elysium & Elysium \\
\hline Enemy & 2013 & Enemy & Neprijatelj \\
\hline Entourage & 2015 & Entourage & Svita \\
\hline Epic & 2013 & Epic - Verborgenes Königreich & Čuvari šume: Tajanstveni svijet \\
\hline Equilibrium & 2002 & Equilibrium & Equilibrium \\
\hline
\end{tabular}




\begin{tabular}{|c|c|c|c|}
\hline Erin Brockovich & 2000 & Erin Brockovich & Erin Brockovich \\
\hline Eternal Sunshine of the Spotless Mind & 2004 & Vergiss mein nicht! & Vječni sjaj nepobjedivog uma \\
\hline Europa Report & 2013 & Europa Report & Izvještaj s Europe \\
\hline EuroTrip & 2004 & Eurotrip & Ludi provod po Europi \\
\hline Event Horizon & 1997 & Event Horizon - Am Rande des Universums & $\begin{array}{l}\text { Konačni horizont } \\
\text { Na rubu horizonta }\end{array}$ \\
\hline Everest & 2015 & Everest & Everest \\
\hline Evil Dead & 2013 & Evil Dead & Zla smrt \\
\hline Ex Machina & 2015 & Ex Machina & Ex Machina \\
\hline Exam & 2009 & Exam - Tödliche Prüfung & Ispit \\
\hline Exodus: Gods and Kings & 2014 & Exodus: Götter und Könige & Egzodus: Bogovi i kraljevi \\
\hline Fair Game & 2010 & Fair Game - Nichts ist gefährlicher als die Wahrheit & Poštena igra \\
\hline Far from the Madding Crowd & 2015 & Am grünen Rand der Welt & Daleko od bjesomučne gomile \\
\hline Fatal Attraction & 1987 & Eine verhängnisvolle Affäre & Kobna privlačnost \\
\hline Fear Isłand & 2009 & & \\
\hline Fifty Shades of Grey & 2015 & Fifty Shades of Grey & Pedeset nijansi sive \\
\hline Final Destination & 2000 & Final Destination & $\begin{array}{l}\text { Put bez povratka } \\
\text { Konačno odredište }\end{array}$ \\
\hline Final Destination 2 & 2003 & Final Destination 2 & Put bez povratka 2 \\
\hline Final Destination 3 & 2006 & Final Destination 3 & Put bez povratka 3 \\
\hline Final Destination 5 & 2011 & Final Destination 5 & Put bez povratka 5 \\
\hline Finding Nemo & 2003 & Findet Nemo & Potraga za Nemom \\
\hline First Daughter & 2004 & First Daughter - Date mit Hindernissen & Predsjednikova kći \\
\hline Flightplan & 2005 & Flightplan - Ohne jede Spur & Red letenja \\
\hline Focus & 2015 & Focus & Fokus \\
\hline Food, Inc. & 2008 & Food, Inc. & Hrana, d. d. \\
\hline Four Lions & 2010 & Four Lions & Četiri lava \\
\hline Foxcatcher & 2014 & Foxcatcher & $\begin{array}{l}\text { Foxcatcher: Priča koja je šokirala } \\
\text { svijet }\end{array}$ \\
\hline Friday the 13th & 2009 & Freitag der 13. & Petak 13. \\
\hline Friends with Benefits & 2011 & Freunde mit gewissen Vorzügen & Veza bez obveza \\
\hline Frozen & 2013 & Die Eiskönigin - Völlig unverfroren & Snježno kraljevstvo \\
\hline Frozen & 2010 & Frozen - Eiskalter Abgrund & Smrznuti \\
\hline Garfield & 2004 & Garfield - Der Film & Garfield \\
\hline Garfield: A Tail of Two Kitties & 2006 & Garfield 2 - Faulheit verpflichtet & Garfield 2 \\
\hline Get Hard & 2015 & Der Knastcoach & Get Hard \\
\hline
\end{tabular}




\begin{tabular}{|c|c|c|c|}
\hline Get Smart & 2008 & Get Smart - Wir lieben es, die Welt zu retten! & Ulovi Smarta \\
\hline Ghost & 1990 & Ghost - Nachricht von Sam & Duh \\
\hline Ghost Ship & 2002 & $\begin{array}{l}\text { Ghost Ship } \\
\text { Ghost Ship - Das Geisterschiff } \\
\text { Ghost Ship - Meer des Grauens }\end{array}$ & Ukleti brod \\
\hline Ginger \& Rosa & 2012 & Ginger \& Rosa & Ginger i Rosa \\
\hline Godzilla & 2014 & Godzilla & Godzilla \\
\hline Gone Girl & 2014 & Gone Girl - Das perfekte Opfer & Nestala \\
\hline Gran Torino & 2008 & Gran Torino & Gran Torino \\
\hline Grandma & 2015 & Grandma & \\
\hline Grandma's Boy & 2006 & Grandma's Boy & Bakin dečko \\
\hline Grave Encounters & 2011 & Grave Encounters & Susreti s mrtvima \\
\hline Grave Encounters 2 & 2012 & Grave Encounters 2 & Susreti s mrtvima 2 \\
\hline Gravity & 2013 & Gravity & Gravitacija \\
\hline Grown Ups & 2010 & Kindsköpfe & Starci \\
\hline Grown Ups 2 & 2013 & Kindsköpfe 2 & Starci 2 \\
\hline Guardians of the Galaxy & 2014 & Guardians of the Galaxy & Čuvari galaksije \\
\hline Hall Pass & 2011 & Alles erlaubt - Eine Woche ohne Regeln & Pušteni s lanca \\
\hline Hard Candy & 2005 & Hard Candy & Gorki slatkiš \\
\hline Harry Potter and the Chamber of Secrets & 2002 & Harry Potter und die Kammer des Schreckens & Harry Potter i Odaja tajni \\
\hline Harry Potter and the Deathly Hallows: Part 1 & 2010 & Harry Potter und die Heiligtümer des Todes - Teil 1 & Harry Potter i Darovi smrti, 1. dio \\
\hline Harry Potter and the Deathly Hallows: Part 2 & 2011 & Harry Potter und die Heiligtümer des Todes - Teil 2 & Harry Potter i Darovi smrti, 2. dio \\
\hline Harry Potter and the Goblet of Fire & 2005 & Harry Potter und der Feuerkelch & Harry Potter i Plameni pehar \\
\hline Harry Potter and the Half-Blood Prince & 2009 & Harry Potter und der Halbblutprinz & Harry Potter i Princ miješane krvi \\
\hline Harry Potter and the Order of the Phoenix & 2007 & Harry Potter und der Orden des Phönix & Harry Potter i Red feniksa \\
\hline Harry Potter and the Philosopher's Stone & 2001 & Harry Potter und der Stein der Weisen & Harry Potter i Kamen mudraca \\
\hline Harry Potter and the Prisoner of Azkaban & 2004 & Harry Potter und der Gefangene von Askaban & Harry Potter i zatočenik Azkabana \\
\hline Haunt & 2014 & Haunt - Das Böse erwacht & Sablast \\
\hline Her & 2013 & Her & Ona \\
\hline He's Just Not That Into You & 2009 & Er steht einfach nicht auf Dich & Njemu baš i nije stalo \\
\hline Hide and Seek & 2005 & Hide and Seek - Du kannst dich nicht verstecken & Igra skrivača \\
\hline High Noon & 1952 & Zwölf Uhr mittags & Točno u podne \\
\hline Holy Motors & 2012 & Holy Motors & Sveti motori \\
\hline Home & 2015 & Home - Ein smektakulärer Trip & Kod kuće \\
\hline Home Alone & 1990 & Kevin - Allein zu Haus & Sam u kući \\
\hline
\end{tabular}




\begin{tabular}{|c|c|c|c|}
\hline Home Alone 2: Lost in New York & 1992 & Kevin - Allein in New York & Sam u kući 2: Izgubljen u New Yorku \\
\hline Home Alone 3 & 1997 & Wieder allein zu Haus & Sam u kući 3 \\
\hline Home Alone 4 & 2002 & $\begin{array}{l}\text { Kevin - Allein gegen alle } \\
\text { Kevin - Allein zu Haus } 4\end{array}$ & Sam u kući 4 \\
\hline Home Alone: The Holiday Heist & 2012 & & Sam u kući 5: Sam u mraku \\
\hline Honey I Blew Up the Kid & 1992 & Liebling, jetzt haben wir ein Riesenbaby & Draga, povećao sam dijete \\
\hline Honey, I Shrunk the Kids & 1989 & Liebling, ich habe die Kinder geschrumpft & Draga, smanjio sam djecu \\
\hline Hope Springs & 2012 & Wie beim ersten Mal & Začin za brak \\
\hline Horrible Bosses & 2011 & Kill the Boss & Kako se riješiti šefa \\
\hline Horrible Bosses 2 & 2014 & Kill the Boss 2 & Kako se riješiti šefa 2 \\
\hline Hostel & 2005 & Hostel & Hostel \\
\hline Hostel: Part II & 2007 & Hostel 2 & Hostel 2 \\
\hline Hostel: Part III & 2011 & Hostel 3 & Hostel 3 \\
\hline Hot Pursuit & 2015 & Miss Bodyguard - In High Heels auf der Flucht & Vruća potjera \\
\hline Hot Shots! & 1991 & Hot Shots! - Die Mutter aller Filme & Kakvi frajeri! \\
\hline Hotel Chevalier & 2007 & Hotel Chevalier & \\
\hline House at the End of the Street & 2012 & House at the End of the Street & Kuća na kraju ulice \\
\hline House of 1000 Corpses & 2003 & Haus der 1000 Leichen & Ukleta kuća \\
\hline House of Wax & 2005 & House of Wax & Kuća voštanih figura \\
\hline How High & 2001 & $\begin{array}{l}\text { So High } \\
\text { American High - Probieren geht über Studieren }\end{array}$ & Totalno napušeni \\
\hline How to Lose a Guy in 10 Days & 2003 & Wie werde ich ihn los - in 10 Tagen? & Kako se riješiti frajera u 10 dana \\
\hline How to Train Your Dragon & 2010 & Drachenzähmen leicht gemacht & Kako izdresirati zmaja \\
\hline How to Train Your Dragon 2 & 2014 & Drachenzähmen leicht gemacht 2 & Kako izdresirati zmaja 2 \\
\hline I Don't Know How She Does It & 2011 & Der ganz normale Wahnsinn - Working Mum & Ne znam kako joj uspijeva \\
\hline I Know What You Did Last Summer & 1997 & Ich weiß, was du letzten Sommer getan hast & Znam što si radila prošlog ljeta \\
\hline I Love You, Man & 2009 & Trauzeuge gesucht! & Čovječe, volim te \\
\hline I Now Pronounce You Chuck and Larry & 2007 & Chuck und Larry - Wie Feuer und Flamme & Chuck, sada možete poljubiti Larryja \\
\hline I Origins & 2014 & I Origins - Im Auge des Ursprungs & I Origins \\
\hline Ice Age & 2002 & Ice Age & Ledeno doba \\
\hline Identity Thief & 2013 & Voll abgezockt & Krađa identiteta \\
\hline In Time & 2011 & In Time - Deine Zeit läuft ab & Vrijeme je novac \\
\hline Inception & 2010 & Inception & Početak \\
\hline Indiana Jones and the Temple of Doom & 1984 & Indiana Jones und der Tempel des Todes & Indiana Jones i ukleti hram \\
\hline India's Daughter & 2014 & & \\
\hline
\end{tabular}




\begin{tabular}{|c|c|c|c|}
\hline Inside Out & 2015 & Alles steht Kopf & Izvrnuto obrnuto \\
\hline Insidious & 2011 & Insidious & Podmuklo \\
\hline Insidious: Chapter 2 & 2013 & Insidious: Chapter 2 & Podmuklo: 2. poglavlje \\
\hline Insidious: Chapter 3 & 2015 & Insidious: Chapter 3 - Jede Geschichte hat einen Anfang & Ukleti: 3. poglavlje \\
\hline Insurgent & 2015 & Die Bestimmung - Insurgent & Trilogija Različita: Pobunjena \\
\hline Interstellar & 2014 & Interstellar & Interstellar \\
\hline Into the Woods & 2014 & Into the Woods & U šumi \\
\hline Intruders & 2011 & Intruders & Uljezi \\
\hline Invictus & 2009 & Invicturs - Unbezwungen & Invictus \\
\hline Iron Man & 2008 & Iron Man & Iron Man \\
\hline Iron Man 2 & 2010 & Iron Man 2 & Iron Man 2 \\
\hline Iron Man 3 & 2013 & Iron Man 3 & Iron Man 3 \\
\hline It Follows & 2014 & It Follows & To dolazi \\
\hline Jack and Jill & 2011 & Jack und Jill & Ludi blizanci \\
\hline John Tucker Must Die & 2006 & Rache ist sexy & John Tucker mora umrijeti \\
\hline Journey 2: The Mysterious Island & 2012 & Die Reise zur geheimnisvollen Insel & $\begin{array}{l}\text { Putovanje u središte zemlje } 2 \text { : } \\
\text { Tajanstveni otok }\end{array}$ \\
\hline Jug Face & 2013 & & \\
\hline Jumanji & 1995 & Jumanji & Jumanji \\
\hline Juno & 2007 & Juno & Juno \\
\hline Jupiter Ascending & 2015 & Jupiter Ascending & Jupiter u usponu \\
\hline Jurassic Park & 1993 & Jurassic Park & Jurski park \\
\hline Jurassic Park III & 2001 & Jurassic Park III & Jurski park 3 \\
\hline Jurassic World & 2015 & Jurassic World & Jurski svijet \\
\hline Just Go with It & 2011 & Meine erfundene Frau & Moja lažna žena \\
\hline Just Married & 2003 & Voll verheiratet & Upravo vjenčani \\
\hline Kill Your Darlings & 2013 & Kill Your Darlings - Junge Wilde & Ubij svoje najdraže \\
\hline Killers & 2010 & Kiss \& Kill & Ubojice \\
\hline Knocked Up & 2007 & Beim ersten Mal & Zalomilo se \\
\hline Kung Fu Panda & 2008 & Kung Fu Panda & Kung fu panda \\
\hline Kung Fu Panda 2 & 2011 & Kung Fu Panda 2 & Kung fu panda 2 \\
\hline Lake Placid & 1999 & $\begin{array}{l}\text { Lake Placid } \\
\text { Lake Placid - Schrecken aus der Tiefe (Fernsehen) }\end{array}$ & Jezero straha \\
\hline Last Holiday & 2006 & Noch einmal Ferien & Posljednji provod \\
\hline Legally Blonde & 2001 & Natürlich blond & Plavuša s Harvarda \\
\hline
\end{tabular}




\begin{tabular}{|c|c|c|c|}
\hline Legally Blonde: Red, White and Blonde & 2003 & Natürlich blond 2 & Plavuša uzvraća udarac \\
\hline Legally Blondes & 2009 & Natürlich blond 3 - Jetzt geht's doppelt weiter & Nove plavuše s Harvarda \\
\hline Legend & 2015 & Legend & Legenda \\
\hline Let's Be Cops & 2014 & Let's be Cops - Die Party Bullen & Lažna patrola \\
\hline Letters to Juliet & 2010 & Briefe an Julia & Pisma Juliji \\
\hline Life as We Know It & 2010 & So spielt das Leben & Kad te ljubav pronađe \\
\hline Lights Out & 2013 & & \\
\hline Like Crazy & 2011 & Like Crazy & Kao ludi \\
\hline Limitless & 2011 & Ohne Limit & Savršena formula \\
\hline Little Ice Age: Big Chill & 2005 & & \\
\hline Little Miss Sunshine & 2006 & Little Miss Sunshine & Mala miss Amerike \\
\hline Love the Coopers & 2015 & Alle Jahre wieder - Weihnachten mit den Coopers & Božić kod Cooperovih \\
\hline Lucy & 2014 & Lucy & Lucy \\
\hline Machete & 2010 & Machete & Machete \\
\hline Machete Kills & 2013 & Machete Kills & Machete ubija \\
\hline Mad Max & 1979 & Mad Max & Pobješnjeli Max \\
\hline Mad Max 2 & 1981 & Mad Max II - Der Vollstrecker & Pobješnjeli Max 2: Cestovni ratnik \\
\hline Mad Max Beyond Thunderdome & 1985 & Mad Max - Jenseits der Donnerkuppel & Pobješnjeli Max 3 \\
\hline Mad Max: Fury Road & 2015 & Mad Max: Fury Road & Pobješnjeli Max: Divlja cesta \\
\hline Made of Honor & 2008 & Verliebt in die Braut & Kako ukrasti nevjestu \\
\hline Magic Mike & 2012 & Magic Mike & Čarobni Mike \\
\hline Maid in Manhattan & 2002 & Manhattan Love Story & Dogodilo se na Manhattanu \\
\hline Maleficent & 2014 & Maleficent - Die dunkle Fee & $\begin{array}{l}\text { Gospodarica zla } \\
\text { Zlurada }\end{array}$ \\
\hline Man on a Ledge & 2012 & Ein riskanter Plan & Na rubu \\
\hline Man on Wire & 2008 & Man on Wire & Čovjek na žici \\
\hline Man Up & 2015 & Es ist kompliziert..! & \\
\hline Maps to the Stars & 2014 & Maps to the Stars & Karta do zvijezda \\
\hline Marley \& Me & 2008 & Marley \& Ich & Marley i ja \\
\hline Match Point & 2005 & Match Point & Završni udarac \\
\hline Max & 2015 & Max - Bester Freund. Held. Retter. & Max \\
\hline Maze Runner: The Scorch Trials & 2015 & Maze Runner - Die Auserwählten in der Brandwüste & Labirint: Kroz spaljenu zemlju \\
\hline Mean Girls & 2004 & Girls Club - Vorsicht bissig! & Opasne djevojke \\
\hline
\end{tabular}




\begin{tabular}{|c|c|c|c|}
\hline Melancholia & 2011 & Melancholia & Melankolija \\
\hline Memento & 2000 & Memento & Memento \\
\hline Midnight in Paris & 2011 & Midnight in Paris & Ponoć u Parizu \\
\hline Minions & 2015 & Minions & Malci \\
\hline Mirror Mirror & 2012 & $\begin{array}{l}\text { Spieglein Spieglein - Die wirklich wahre Geschichte von } \\
\text { Schneewittchen }\end{array}$ & Snjeguljica \\
\hline Mirrors & 2008 & Mirrors & Zrcala \\
\hline Miss Potter & 2006 & Miss Potter & Gospođica Potter \\
\hline Mission: Impossible & 1996 & Mission: Impossible & Nemoguća misija \\
\hline Mission: Impossible II & 2000 & Mission: Impossible II & Nemoguća misija 2 \\
\hline Mona Lisa Smile & 2003 & Mona Lisas Lächeln & Osmijeh Mona Lise \\
\hline Monster-in-Law & 2005 & Das Schwiegermonster & Za sve je kriva svekrva \\
\hline Monster's Ball & 2001 & Monster's Ball & Bal čudovišta \\
\hline Monsters, Inc. & 2001 & Die Monster AG & Čudovišta iz ormara \\
\hline Moon & 2009 & Moon & Mjesec \\
\hline Movie 43 & 2013 & Movie 43 & Film 43 \\
\hline Mr. Peabody \& Sherman & 2014 & Die Abenteuer von Mr. Peabody \& Sherman & $\begin{array}{l}\text { Avanture gospodina Peabodya i } \\
\text { Shermana }\end{array}$ \\
\hline Mulholland Drive & 2001 & Mulholland Drive - Straße der Finsternis & Bulevar zločina \\
\hline Music Box & 1989 & Music Box - Die ganze Wahrheit & Muzička kutija \\
\hline My Best Friend's Wedding & 1997 & Die Hochzeit meines besten Freundes & Moj dečko se ženi \\
\hline My Life in Ruins & 2009 & My Big Fat Greek Summer & Moja grčka avantura \\
\hline My Mom's New Boyfriend & 2008 & Lauschangriff - My Mom's New Boyfriend & Mamin novi frajer \\
\hline My Sister's Keeper & 2009 & Beim Leben meiner Schwester & Čuvarica svoje sestre \\
\hline National Lampoon's Vacation & 1983 & Die schrillen Vier auf Achse & $\begin{array}{l}\text { Godišnji odmor snova } \\
\text { Ludi odmor }\end{array}$ \\
\hline National Treasure & 2004 & Das Vermächtnis der Tempelritter & Nacionalno blago \\
\hline National Treasure: Book of Secrets & 2007 & Das Vermächtnis des geheimen Buches & Nacionalno blago: Knjiga tajni \\
\hline Nebraska & 2013 & Nebraska & Nebraska \\
\hline Neighbors & 2014 & Bad Neighbors & Susjedi iz pakla \\
\hline New in Town & 2009 & New in Town & Gradska cura \\
\hline New Year's Eve & 2011 & Happy New Year & Sretna Nova godina! \\
\hline Nightcrawler & 2014 & Nightcrawler - Jede Nacht hat ihren Preis & Noćne kronike \\
\hline No Escape & 2015 & & \\
\hline
\end{tabular}




\begin{tabular}{|c|c|c|c|}
\hline Noah & 2014 & Noah & Noa \\
\hline Non-Stop & 2014 & Non-Stop & Non Stop \\
\hline Not Another Teen Movie & 2001 & Nicht noch ein Teenie-Film! & $\begin{array}{l}\text { To nije još jedan film za mlade } \\
\text { Ovo nije glupi film za mlade }\end{array}$ \\
\hline Nothing but the Truth & 2008 & Nichts als die Wahrheit & Predsjednička igra \\
\hline Now You See Me & 2013 & Die Unfassbaren - Now You See Me & Majstori iluzije \\
\hline Oblivion & 2013 & Oblivion & Zaborav \\
\hline Oculus & 2013 & Oculus - Das Böse ist in dir & Ogledalo smrti \\
\hline One Day & 2011 & Zwei an einem Tag & Jedan dan \\
\hline Orphan & 2009 & Orphan - Das Waisenkind & Siroče \\
\hline Our Idiot Brother & 2011 & Our Idiot Brother & Naš brat idiot \\
\hline P.S. I Love You & 2007 & P.S. Ich liebe Dich & P.S. Volim te \\
\hline Pandorum & 2009 & Pandorum & Pandorum \\
\hline Panic Room & 2002 & Panic Room & Soba panike \\
\hline Paper Towns & 2015 & Margos Spuren & Gradovi na papiru \\
\hline Paranormal Activity & 2007 & Paranormal Activity & Paranormalno \\
\hline Paranormal Activity 2 & 2010 & Paranormal Activity 2 & Paranormalno 2 \\
\hline Paranormal Activity 3 & 2011 & Paranormal Activity 3 & Paranormalno 3 \\
\hline Parkland & 2013 & Parkland & Parkland \\
\hline Passengers & 2008 & Passengers & Putnici \\
\hline Pathology & 2008 & Pathology - Jeder hat ein Geheimnis & Patologija \\
\hline Paul Blart: Mall Cop & 2009 & Der Kaufhaus Cop & Policajac iz shopping centra \\
\hline Phoenix & 2014 & N/A & Feniks \\
\hline Piranha 3D & 2010 & Piranha 3D & Piranha 3D \\
\hline Pitch Perfect & 2012 & Pitch Perfect & Na putu do zvijezda \\
\hline Pitch Perfect 2 & 2015 & Pitch Perfect 2 & Na putu do zvijezda 2 \\
\hline Planet of the Apes & 2001 & Planet der Affen & Planet majmuna \\
\hline Planet of the Apes & 1968 & Planet der Affen & Planet majmuna \\
\hline Pompeii & 2014 & Pompeii & Pompeji \\
\hline Predestination & 2014 & Predestination & Predodređenje \\
\hline Premonition & 2007 & Die Vorahnung & Slutnja \\
\hline Pretty Woman & 1990 & Pretty Woman & Zgodna žena \\
\hline Pride & 2014 & Pride & Ponos \\
\hline Primat & 2010 & & \\
\hline Primal Fear & 1996 & Zwielicht & Iskonski strah \\
\hline
\end{tabular}




\begin{tabular}{|c|c|c|c|}
\hline Prime & 2005 & Couchgeflüster - Die erste therapeutische Liebeskomödie & Mlađe je slađe \\
\hline Prisoners & 2013 & Prisoners & Zatočene \\
\hline Prometheus & 2012 & Prometheus - Dunkle Zeichen & Prometej \\
\hline Psycho & 1960 & Psycho & Psiho \\
\hline Puff, Puff, Pass & 2006 & Living High - Was für ein Trip! & Povuci, povuci, proslijedi \\
\hline Pulp Fiction & 1994 & Pulp Fiction & Pakleni šund \\
\hline Pulse & 2006 & Pulse - Du bist tot, bevor Du stirbst & Impuls \\
\hline Puss in Boots & 2011 & Der gestiefelte Kater & Mačak u čizmama \\
\hline Quantum of Solace & 2008 & James Bond 007: Ein Quantum Trost & Zrno utjehe \\
\hline Quarantine & 2008 & Quarantäne & Karantena \\
\hline Raiders of the Lost Ark & 1981 & Jäger des verlorenen Schatzes & $\begin{array}{l}\text { Otimači izgubljenog kovčega } \\
\text { Indiana Jones i otimači izgubljenog } \\
\text { kovčega }\end{array}$ \\
\hline Rear Window & 1954 & Das Fenster zum Hof & Prozor u dvorište \\
\hline RED & 2010 & R.E.D. - Älter. Härter. Besser. & RED \\
\hline RED 2 & 2013 & R.E.D. 2 & $\begin{array}{l}\text { Red 2: Umirovljeni, naoružani i } \\
\text { iznimno opasni }\end{array}$ \\
\hline Red Eye & 2005 & Red Eye - Nachtflug in den Tod & Noćni let \\
\hline Regression & 2015 & Regression & \\
\hline Remember Me & 2010 & Remember Me - Lebe den Augenblick & Hvala ti za ljubav \\
\hline Reservoir Dogs & 1992 & Reservoir Dogs - Wilde Hunde & $\begin{array}{l}\text { Reservoir Dogs } \\
\text { Psi iz rezervoara }\end{array}$ \\
\hline Revolutionary Road & 2008 & Zeiten des Aufruhrs & Put oslobođenja \\
\hline Ricki and the Flash & 2015 & Ricki - Wie Familie so ist & Rock kraljica \\
\hline Rio & 2011 & Rio & Rio \\
\hline Rise of the Planet of the Apes & 2011 & Planet der Affen: Prevolution & Planet majmuna: Postanak \\
\hline Role Models & 2008 & Vorbilder?! & Mentori za nevolje \\
\hline Rosemary's Baby & 1968 & Rosemaries Baby & $\begin{array}{l}\text { Rosemaryna beba } \\
\text { Rosemaryno dijete }\end{array}$ \\
\hline Rush & 2013 & Rush - Alles für den Sieg & Utrka života \\
\hline Saw & 2004 & $\begin{array}{l}\text { Saw } \\
\text { Saw - Wessen Blut wird fliessen? (Schweiz) }\end{array}$ & Slagalica strave \\
\hline Saw 3D & 2010 & Saw 3D - Vollendung & Slagalica strave 3D \\
\hline Scary Movie & 2000 & Scary Movie & Mrak film \\
\hline Scary Movie 5 & 2013 & Scary Movie 5 & Mrak film 5 \\
\hline
\end{tabular}




\begin{tabular}{|c|c|c|c|}
\hline School for Scoundrels & 2006 & Der Date Profi & Škola za frajere \\
\hline Scott Pilgrim vs. the World & 2010 & Scott Pilgrim gegen den Rest der Welt & Scott Pilgrim protiv svijeta \\
\hline Secret Window & 2004 & Das geheime Fenster & Tajni prozor \\
\hline Selma & 2014 & Selma & Selma \\
\hline Seven Pounds & 2008 & Sieben Leben & Sedam duša \\
\hline Sex Tape & 2014 & Sex Tape & Snimka seksa \\
\hline Shadow Dancer & 2012 & Shadow Dancer & Čovjek iz sjene \\
\hline Shaun of the Dead & 2004 & Shaun of the Dead & Noć glupih mrtvaca \\
\hline She's Out of My League & 2010 & Zu scharf um wahr zu sein & Jednostavno savršena \\
\hline She's the Man & 2006 & She's the Man - Voll mein Typ! & Ona je najbolja \\
\hline Shrek & 2001 & Shrek - Der tollkühne Held & Shrek \\
\hline Shrek 2 & 2004 & Shrek 2 - Der tollkühne Held kehrt zurück & Shrek 2 \\
\hline Shrek Forever After & 2010 & Für immer Shrek & Shrek uvijek i zauvijek \\
\hline Shrek the Third & 2007 & Shrek der Dritte & Shrek Treći \\
\hline Shutter Island & 2010 & Shutter Island & Otok Shutter \\
\hline Sicario & 2015 & Sicario & Sicario \\
\hline Side Effects & 2013 & Side Effects - Tödliche Nebenwirkungen & Nuspojave \\
\hline Signs & 2002 & Signs - Zeichen & Misteriozni znakovi \\
\hline Silent Hill & 2006 & Silent Hill - Willkommen in der Hölle & Silent Hill \\
\hline Silent Hill: Revelation 3D & 2012 & Silent Hill: Revelation 3D & Silent Hill: Otkrivenje 3D \\
\hline Silent House & 2011 & Silent House - Die Stille wird dich töten! & Kuća tišine \\
\hline Silver Linings Playbook & 2012 & Silver Linings & U dobru i zlu \\
\hline Sinister & 2012 & Sinister & Zla kob \\
\hline Skinny Jeans & 2012 & & \\
\hline Skyfall & 2012 & James Bond 007: Skyfall & Skyfall \\
\hline Sleepy Hollow & 1999 & Sleepy Hollow & Sanjiva dolina \\
\hline Snowpiercer & 2013 & Snowpiercer & Snowpiercer \\
\hline Solaris & 2002 & Solaris & Solaris \\
\hline Source Code & 2011 & Source Code & Izvorni kod \\
\hline Southpaw & 2015 & Southpaw & Lijevi kroše \\
\hline Spectre & 2015 & James Bond 007: Spectre & Spectre \\
\hline Splice & 2009 & Splice - Das Genexperiment & Hibrid \\
\hline Spy & 2015 & Spy - Susan Cooper Undercover & Špijunka \\
\hline St. Vincent & 2014 & St. Vincent & Vincent \\
\hline
\end{tabular}




\begin{tabular}{|c|c|c|c|}
\hline Star Leaf & 2015 & & \\
\hline State of Play & 2009 & State of Play - Stand der Dinge & U vrtlogu igre \\
\hline Stay Alive & 2006 & Stay Alive & Igra smrti \\
\hline Steve Jobs & 2015 & Steve Jobs & Steve Jobs \\
\hline Still Alice & 2014 & Still Alice - Mein Leben ohne Gestern & Zauvijek Alice \\
\hline Straight Outta Compton & 2015 & Straight Outta Compton & Straight Outta Compton \\
\hline Stuck in Love & 2012 & Love Stories & Izgubljeni u ljubavi \\
\hline Sunshine & 2007 & Sunshine & Sunce \\
\hline Super Size Me & 2004 & Super Size Me & Super veliki ja \\
\hline Superbad & 2007 & Superbad & Superbad \\
\hline Surviving Christmas & 2004 & Wie überleben wir Weihnachten? & Kako preživjeti Božić \\
\hline Sydney White & 2007 & Sydney White - Campus Queen & Super luzeri \\
\hline Tangled & 2010 & Rapunzel - Neu verföhnt & Vrlo zapetljana priča \\
\hline Tangled Ever After & 2012 & Rapunzel - Verföhnt, Verlobt, Verheiratet & Do kraja zapetljana priča \\
\hline Ted & 2012 & Ted & Ted \\
\hline Teeth & 2007 & Teeth - Wer zuletzt beißt, beißt am besten & Zubi \\
\hline Terminator 2: Judgement Day & 1991 & Terminator 2 - Tag der Abrechnung & Terminator 2: Sudnji dan \\
\hline Terminator 3: Rise of the Machines & 2003 & Terminator 3 - Rebellion der Maschinen & Terminator 3: Pobuna strojeva \\
\hline Terminator Genisys & 2015 & Terminator: Genisys & Terminator: Genisys \\
\hline Terminator Salvation & 2009 & Terminator: Die Erlösung & Terminator: Spasenje \\
\hline Texas Chainsaw 3D & 2013 & Texas Chainsaw 3D - The Legend Is Back & Teksaški masakr motornom pilom 3D \\
\hline That Awkward Moment & 2014 & Für immer Single? & Onaj osjećaj kad... \\
\hline That's My Boy & 2012 & Der Chaos-Dad & Tatin sin \\
\hline The Abandoned & 2006 & The Abandoned - Die Verlassenen & Ostavljena \\
\hline The Adjustment Bureau & 2011 & Der Plan & Nemogući susret \\
\hline The Adventures of Tintin & 2011 & $\begin{array}{l}\text { Die Abenteuer von Tim und Struppi - Das Geheimnis der } \\
\text { Einhorn }\end{array}$ & $\begin{array}{l}\text { Avanture Tintina } \\
\text { Tintinove pustolovine }\end{array}$ \\
\hline The Age of Stupid & 2009 & The Age of Stupid - warum tun wir nichts? & $\begin{array}{l}\text { Doba gluposti } \\
\text { Era glupih }\end{array}$ \\
\hline The American & 2010 & The American & Amerikanac \\
\hline
\end{tabular}




\begin{tabular}{|c|c|c|c|}
\hline The Amityville Horror & 1979 & Amityville Horror & Amityville horor \\
\hline The Amityville Horror & 2005 & Amityville Horror - Eine wahre Geschichte & Amityville horor \\
\hline The Apparition & 2012 & Apparition - Dunkle Erscheinung & Utvara \\
\hline The Artist & 2011 & The Artist & Umjetnik \\
\hline The Astronaut Farmer & 2006 & Astronaut Farmer & Astronaut farmer \\
\hline The Astronaut's Wife & 1999 & The Astronaut's Wife - Das Böse hat ein neues Gesicht & Astronautova žena \\
\hline The Avengers & 2012 & Marvel's The Avengers & Osvetnici \\
\hline The Awakening & 2011 & $\begin{array}{l}\text { The Awakening: Geister der Vergangenheit } \\
\text { The Awakening - Geister der Vergangenheit (SUI) } \\
\text { Geister der Vergangenheit (naslov za televiziju) }\end{array}$ & Buđenje \\
\hline The Babadook & 2014 & Der Babadook & \\
\hline The Bank Job & 2008 & Bank Job & Pljačka \\
\hline The Bay & 2012 & The Bay - Nach Angst kommt Panik & Zaljev \\
\hline The Big Wedding & 2013 & The Big Wedding & Vjenčanje godine \\
\hline The Birds & 1963 & Die Vögel & Ptice \\
\hline The Blair Witch Project & 1999 & Blair Witch Project & Projekt: Vještica iz Blaira \\
\hline The Blind Side & 2009 & Blind Side - Die große Chance & Priča o prvaku \\
\hline The Bling Ring & 2013 & The Bling Ring & Bling Ring \\
\hline The Blob & 1988 & Der Blob & Mjehur ubojica \\
\hline The Bodyguard & 1992 & Bodyguard & Tjelohranitelj \\
\hline The Bone Collector & 1999 & Der Knochenjäger & Sakupljač kostiju \\
\hline The Book of Life & 2014 & Manolo und das Buch des Lebens & Knjiga života \\
\hline The Bourne Identity & 2002 & Die Bourne Identität & Bourneov identitet \\
\hline The Bourne Legacy & 2012 & Das Bourne Vermächtnis & Bourneovo nasljeđe \\
\hline The Bourne Supremacy & 2004 & Die Bourne Verschwörung & Bourneova nadmoć \\
\hline The Bourne Ultimatum & 2007 & Das Bourne Ultimatum & Bourneov ultimatum \\
\hline The Boxtrolls & 2014 & Die Boxtrolls & \\
\hline The Breakfast Club & 1985 & Der Frühstücksclub & Klub ranoranilaca \\
\hline The Butterfly Effect & 2004 & Butterfly Effect & Domino efekt \\
\hline The Cabin in the Woods & 2012 & The Cabin in the Woods & Koliba u šumi \\
\hline The Call & 2013 & The Call - Leg nicht auf! & Poziv \\
\hline The Canal & 2014 & & \\
\hline The Captive & 2014 & The Captive: Spurlos verschwunden & \\
\hline The Cave & 2004 & The Cave & Špilja straha \\
\hline
\end{tabular}




\begin{tabular}{|c|c|c|c|}
\hline The Cavern & 2005 & The Cavern - Abstieg ins Grauen & \\
\hline The Collection & 2012 & The Collection - The Collector 2 & Kolekcija \\
\hline The Collector & 2009 & The Collector: He Always Takes One & Kolekcionar \\
\hline The Conjuring & 2013 & Conjuring - Die Heimsuchung & Prizivanja \\
\hline The Croods & 2013 & Die Croods & Croods \\
\hline The Crypt & 2009 & The Crypt - Gruft des Grauens & \\
\hline The Da Vinci Code & 2006 & The Da Vinci Code - Sakrileg & Da Vincijev kod \\
\hline The Darjeeling Limited & 2007 & Darjeeling Limited & Darjeeling d.o.o. \\
\hline The Debt & 2010 & Eine offene Rechnung & Dug \\
\hline The Descent & 2005 & The Descent - Abgrund des Grauens & Špilja užasa \\
\hline The Descent: Part 2 & 2009 & The Descent 2 - Die Jagd geht weiter & Špilja užasa 2 \\
\hline The Devil Wears Prada & 2006 & Der Teufel trägt Prada & Vrag nosi Pradu \\
\hline The Dilemma & 2011 & Dickste Freunde & Šutnja (ni)je zlato \\
\hline The Drop & 2014 & The Drop - Bargeld & Prljavi novac \\
\hline The DUFF & 2015 & DUFF: Hast du keine, bist du eine & Kako postati popularna \\
\hline The Equalizer & 2014 & The Equalizer & Pravednik \\
\hline The Eye & 2008 & The Eye & Oko \\
\hline The Family & 2013 & Malavita - The Family & Malavita \\
\hline The Fault in Our Stars & 2014 & Das Schicksal ist ein mieser Verräter & Krive su zvijezde \\
\hline The Fifth Element & 1997 & Das fünfte Element & Peti element \\
\hline The Fifth Estate & 2013 & Inside WikiLeaks - Die fünfte Gewalt & Tajne petog staleža \\
\hline The Final Destination & 2009 & Final Destination 4 & Put bez povratka 4 \\
\hline The Five-Year Engagement & 2012 & Fast verheiratet & Vječni zaručnici \\
\hline The Fog & 2005 & The Fog - Nebel des Grauens & Magla \\
\hline The Fourth Kind & 2009 & Die vierte Art & Susreti četvrte vrste \\
\hline The Ghost Writer & 2010 & Der Ghostwriter & Pisac iz sjene \\
\hline The Gift & 2015 & The Gift & Dar \\
\hline The Girl Next Door & 2004 & The Girl Next Door & Djevojka iz susjedstva \\
\hline The Girl with the Dragon Tatoo & 2011 & Verblendung & Muškarci koji mrze žene \\
\hline The Giver & 2014 & Hüter der Erinnerung - The Giver & Davatelj \\
\hline The Godfather & 1972 & Der Pate & Kum \\
\hline The Good Lie & 2014 & The Good Lie - Der Preis der Freiheit & Nevina laž \\
\hline The Goonies & 1985 & Die Goonies & Goonies \\
\hline The Grand Budapest Hotel & 2014 & $\begin{array}{l}\text { Grand Budapest Hotel } \\
\text { The Grand Budapest Hotel (Švicarska) }\end{array}$ & Hotel Grand Budapest \\
\hline
\end{tabular}




\begin{tabular}{|c|c|c|c|}
\hline The Great Gatsby & 2013 & Der große Gatsby & Veliki Gatsby \\
\hline The Green Inferno & 2013 & & \\
\hline The Grey & 2011 & The Grey - Unter Wölfen & Opstanak \\
\hline The Hangover & 2009 & Hangover & Mamurluk \\
\hline The Hangover Part II & 2011 & Hangover 2 & Mamurluk 2 \\
\hline The Hangover Part III & 2013 & Hangover 3 & Mamurluk 3 \\
\hline The Happening & 2008 & The Happening & Događaj \\
\hline The Heat & 2013 & Taffe Mädels & Specijalne agentice \\
\hline The Help & 2011 & The Help & Tajni život kućnih pomoćnica \\
\hline The Hills Have Eyes & 2006 & The Hills Have Eyes - Hügel der blutigen Augen & Brda imaju oči \\
\hline The Hills Have Eyes II & 2007 & The Hills Have Eyes 2 & Brda imaju oči 2 \\
\hline The Hitchhiker's Guide to the Galaxy & 2005 & Per Anhalter durch die Galaxis & Vodič kroz galaksiju za autostopere \\
\hline The Hobbit: An Unexpected Journey & 2012 & Der Hobbit: Eine unerwartete Reise & Hobit: Neočekivano putovanje \\
\hline The Hobbit: The Battle of Five Armies & 2014 & Der Hobbit: Die Schlacht der fünf Heere & Hobit: Bitka pet vojski \\
\hline The Hobbit: The Desolation of Smaug & 2013 & Der Hobbit: Smaugs Einöde & Hobit: Smaugova pustoš \\
\hline The House Bunny & 2008 & House Bunny & Kućna zečica \\
\hline The Human Centipede (First Sequence) & 2009 & Human Centipede - Der menschliche Tausendfüßler & Ljudska stonoga \\
\hline The Hundred-Foot Journey & 2014 & Madame Mallory und der Duft von Curry & Indijski začin na francuski način \\
\hline The Hunger Games & 2012 & Die Tribute von Panem - The Hunger Games & Igre gladi \\
\hline The Hunger Games: Catching Fire & 2013 & Die Tribute von Panem - Catching Fire & Igre gladi: Plamen \\
\hline The Hunger Games: Mockingjay - Part 1 & 2014 & Die Tribute von Panem - Mockingjay: Teil 1 & Igre gladi: Šojka rugalica 1. dio \\
\hline The Hunger Games: Mockingjay - Part 2 & 2015 & Die Tribute von Panem - Mockingjay: Teil 2 & Igre gladi: Šojka rugalica 2. dio \\
\hline The Hurt Locker & 2008 & Tödliches Kommando - The Hurt Locker & Narednik James \\
\hline The Illusionist & 2006 & The Illusionist - Nichts ist wie es scheint & Iluzionist \\
\hline The Imitation Game & 2014 & The Imitation Game - Ein streng geheimes Leben & Igra oponašanja \\
\hline The Imposter & 2012 & Der Blender - The Imposter & Uljez \\
\hline The Incredible Hulk & 2008 & Der unglaubliche Hulk & Nevjerojatni Hulk \\
\hline The Innkeepers & 2011 & The Innkeepers - Hotel des Schreckens & Šapat duhova \\
\hline The Intern & 2015 & Man lernt nie aus & Pripravnik \\
\hline The Internship & 2013 & $\begin{array}{l}\text { Prakti.com } \\
\text { Generation Praktikum (pre-release) }\end{array}$ & Pripravnici \\
\hline The Interpreter & 2005 & Die Dolmetscherin & Prevoditeljica \\
\hline The Interview & 2014 & The Interview & Najluđi intervju \\
\hline The Invasion & 2007 & Invasion & Invazija \\
\hline
\end{tabular}




\begin{tabular}{|c|c|c|c|}
\hline The Invention of Lying & 2009 & Lügen macht erfinderisch & Umijeće laganja \\
\hline The Iron Lady & 2011 & Die Eiserne Lady & $\begin{array}{l}\text { Željezna lady } \\
\text { Željezna dama } \\
\text { Čelična lady }\end{array}$ \\
\hline The Island & 2005 & Die Insel & Otok \\
\hline The Judge & 2014 & Der Richter - Recht oder Ehre & Sudac \\
\hline The Kings of Summer & 2013 & Kings of Summer & Kraljevi ljeta \\
\hline The King's Speech & 2010 & The King's Speech - Die Rede des Königs & Kraljev govor \\
\hline The Last Days on Mars & 2013 & Last Days on Mars & Posljednji dani na Marsu \\
\hline The Last Exorcism & 2010 & Der letzte Exorzismus & Posljednji egzorcizam \\
\hline The Last Exorcism Part II & 2013 & Der letzte Exorzismus: The Next Chapter & Posljednji egzorcizam 2 \\
\hline The Last House on the Left & 2009 & Last House on the Left & Posljednja kuća nalijevo \\
\hline The Last Witch Hunter & 2015 & The Last Witch Hunter & Posljednji lovac na vještice \\
\hline The Lazarus Effect & 2015 & & Lazarov efekt \\
\hline The Lego Movie & 2014 & The LEGO Movie & Lego \\
\hline The Link & 2009 & & \\
\hline The Lion King & 1994 & Der König der Löwen & Kralj lavova \\
\hline The Lizzie McGuire Movie & 2003 & Popstar auf Umwegen & Najluđi provod u Europi \\
\hline The Lord of the Rings: The Fellowship of the Ring & 2001 & Der Herr der Ringe - Die Gefährten & $\begin{array}{l}\text { Gospodar prstenova: Prstenova } \\
\text { družina }\end{array}$ \\
\hline The Lord of the Rings: The Return of the King & 2003 & Der Herr der Ringe - Die Rückkehr des Königs & Gospodar prstenova: Povratak kralja \\
\hline The Lord of the Rings: The Two Towers & 2002 & Der Herr der Ringe - Die zwei Türme & Gospodar prstenova: Dvije kule \\
\hline The Lost World: Jurassic Park & 1997 & Vergessene Welt: Jurassic Park & Jurski park 2: Izgubljeni svijet \\
\hline The Machine & 2013 & The Machine & Stroj \\
\hline The Man from Earth & 2007 & The Man from Earth & Čovjek sa Zemlje \\
\hline The Man from U.N.C.L.E. & 2015 & Codename U.N.C.L.E. & Šifra U.N.C.L.E. \\
\hline The Martian & 2015 & Der Marsianer - Rettet Mark Watney & Marsovac \\
\hline The Matrix & 1999 & Matrix & Matrix \\
\hline The Matrix Reloaded & 2003 & Matrix Reloaded & Matrix Reloaded \\
\hline The Matrix Revolutions & 2003 & Matrix Revolutions & Matrix Revolutions \\
\hline The Maze Runner & 2014 & Maze Runner - Die Auserwählten im Labyrinth & Labirint: Nemogući bijeg \\
\hline The Mist & 2007 & Der Nebel & Magla \\
\hline The Monuments Men & 2014 & Monuments Men - Ungewöhnliche Helden & Odred za baštinu \\
\hline The Mummy & 1999 & Die Mumie & Mumija \\
\hline The Normal Heart & 2014 & The Normal Heart & Normalno srce \\
\hline
\end{tabular}




\begin{tabular}{|c|c|c|c|}
\hline The Other Woman & 2014 & Die Schadenfreundinnen & Osveta na visokim petama \\
\hline The Others & 2001 & The Others & $\begin{array}{l}\text { Nevidljivi } \\
\text { Uljezi }\end{array}$ \\
\hline The Pact & 2012 & & Savez \\
\hline The Parent Trap & 1998 & Ein Zwilling kommt selten allein & Zamka za roditelje \\
\hline The Pelican Brief & 1993 & Die Akte & Slučaj Pelikan \\
\hline The Perks of Being a Wallflower & 2012 & Vielleicht lieber morgen & Charliejev svijet \\
\hline The Physician & 2013 & Der Medicus & Iscjeljitelj \\
\hline The Place Beyond the Pines & 2012 & The Place Beyond the Pines & Grijesi očeva \\
\hline The Possession & 2012 & Possession - Das Dunkle in dir & Opsjednuta \\
\hline The Prestige & 2006 & Prestige - Die Meister der Magie & Prestiž \\
\hline The Princess Diaries & 2001 & Plötzlich Prinzessin! & $\begin{array}{l}\text { Princezini dnevnici: Odjednom } \\
\text { princeza }\end{array}$ \\
\hline The Princess Diaries 2: Royal Engagement & 2004 & Plötzlich Prinzessin 2 & Princezini dnevnici: Kraljevske zaruke \\
\hline The Proposal & 2009 & Selbst ist die Braut & Prisila na brak \\
\hline The Purge & 2013 & The Purge - Die Säuberung & Pročišćenje \\
\hline The Purge: Anarchy & 2014 & The Purge: Anarchy & Pročišćenje 2 \\
\hline The Pyramid & 2014 & The Pyramid - Grab des Grauens & \\
\hline The Rebound & 2009 & Lieber verliebt & Ljubavni jackpot \\
\hline The Rite & 2011 & The Rite - Das Ritual & Obred \\
\hline The Ruins & 2008 & Ruinen & Ruševine \\
\hline The Salvation & 2014 & The Salvation - Spur der Vergeltung & The Salvation \\
\hline The School of Rock & 2003 & School of Rock & Rock'n'roll škola \\
\hline The Secret of Kells & 2009 & $\begin{array}{l}\text { Brendan und das Geheimnis von Kells } \\
\text { Das Geheimnis von Kells (DVD) }\end{array}$ & Tajna Kellsa \\
\hline The Shawshank Redemption & 1994 & Die Verurteilten & Iskupljenje u Shawshanku \\
\hline The Signal & 2014 & The Signal & Signal \\
\hline The Silence of the Lambs & 1991 & Das Schweigen der Lämmer & Kad jaganjci utihnu \\
\hline The Sitter & 2011 & Bad Sitter & Dadilja \\
\hline The Sixth Sense & 1999 & Sixth Sense & Šesto čulo \\
\hline The Skeleton Key & 2005 & Der verbotene Schlüssel & Ključ tajni \\
\hline The Skeleton Twins & 2014 & & Kosturski blizanci \\
\hline The Starving Games & 2013 & Die Pute von Panem - The Starving Games & Igre izgladnjivanja \\
\hline The Station Agent & 2003 & Station Agent & Čuvar stanice \\
\hline The Strangers & 2008 & The Strangers & Stranci \\
\hline The Switch & 2010 & Umständlich verliebt & Zamjena \\
\hline
\end{tabular}




\begin{tabular}{|c|c|c|c|}
\hline The Terminator & 1984 & Terminator & Terminator \\
\hline The Texas Chain Saw Massacre & 1974 & $\begin{array}{l}\text { Blutgericht in Texas (Kino) } \\
\text { Kettensägenmassaker (Video) } \\
\text { The Texas Chainsaw Massacre (Blu-ray Disc/DVD 2012) }\end{array}$ & Teksaški masakr motornom pilom \\
\hline The Thaw & 2009 & Frozen - Etwas hat überlebt & Otapanje \\
\hline The Theory of Everything & 2014 & Die Entdeckung der Unendlichkeit & Teorija svega \\
\hline The Thing & 2011 & The Thing & Stvor \\
\hline The Time Traveler's Wife & 2009 & Die Frau des Zeitreisenden & Žena vremenskog putnika \\
\hline The Truman Show & 1998 & Die Truman Show & Trumanov show \\
\hline The Ugly Truth & 2009 & Die nackte Wahrheit & Gola istina \\
\hline The Unborn & 2009 & The Unborn & Izgubljena duša \\
\hline The Village & 2004 & The Village - Das Dorf & Zaselak \\
\hline The Vow & 2012 & Für immer Liebe & Zavjet ljubavi \\
\hline The Way & 2010 & Dein Weg & Put \\
\hline The Wedding Ringer & 2015 & Die Trauzeugen AG & Gospodar vjenčanja \\
\hline The Whistleblower & 2010 & Whistleblower - In gefährlicher Mission & Zviždačica \\
\hline The Wolf of Wall Street & 2013 & The Wolf of Wall Street & Vuk s Wall Streeta \\
\hline The Wolverine & 2013 & Wolverine: Weg des Kriegers & Wolverine \\
\hline The Woman in Black & 2012 & Die Frau in Schwarz & Žena u crnom \\
\hline This Is the End & 2013 & Das ist das Ende & Ovo je kraj \\
\hline This Is Where I Leave You & 2014 & Sieben verdammt lange Tage & Sad te ostavljam \\
\hline This Means War & 2012 & Das gibt Ärger & Neka bolji pobijedi \\
\hline Thor & 2011 & Thor & Thor \\
\hline Thor: The Dark World & 2013 & Thor - The Dark Kingdom & Thor: Svijet tame \\
\hline Titanic & 1997 & Titanic & Titanik \\
\hline Tomorrowland & 2015 & A World Beyond & Sutrozemlja: Novi svijet \\
\hline Top Gun & 1986 & Top Gun - Sie fürchten weder Tod noch Teufel & Top Gun \\
\hline Toy Story & 1995 & Toy Story & Priča o igračkama \\
\hline Toy Story 2 & 1999 & Toy Story 2 & Priča o igračkama 2 \\
\hline Toy Story 3 & 2010 & Toy Story 3 & Priča o igračkama 3 \\
\hline Trainwreck & 2015 & Dating Queen & Kaos u glavi \\
\hline Transcendence & 2014 & Transcendence & Uzvišenost \\
\hline Transsiberian & 2008 & Transsiberian & Transsibirska pruga smrti \\
\hline T Rex: Back to the Cretaceous & 1998 & & \\
\hline
\end{tabular}




\begin{tabular}{|c|c|c|c|}
\hline Trust & 2010 & $\begin{array}{l}\text { Trust - Blindes Vertrauen } \\
\text { Trust - Die Spur führt ins Netz (DVD) }\end{array}$ & Povjerenje \\
\hline Twenty Feet from Stardom & 2013 & 20 Feet from Stardom - Dem Ruhm zum Greifen nah & Pet metara od slave \\
\hline Under the Skin & 2013 & Under the Skin - Tödliche Verführung & Pod kožom \\
\hline Underground & 2011 & Underground - Tödliche Bestien & Podzemlje \\
\hline Unearthed & 2007 & Unearthed Monster & Otkopan \\
\hline Unfriended & 2014 & Unknown User & Odklikana \\
\hline Up & 2009 & Oben & Nebesa \\
\hline Upside Down & 2012 & Upside Down & Zabranjena ljubav \\
\hline V for Vendetta & 2005 & V wie Vendetta & O za osvetu \\
\hline Venom & 2005 & Venom - Biss der Teufelsschlangen & Otrov \\
\hline Vertigo & 1958 & Vertigo - Aus dem Reich der Toten & Vrtoglavica \\
\hline Waking Life & 2001 & Waking Life & Probuđeni život \\
\hline Walk of Shame & 2014 & Mädelsabend - Nüchtern zu schüchtern! & Najgora noć u životu \\
\hline WALL·E & 2008 & WALL $\cdot E$ - Der Letzte räumt die Erde auf & WALL·E \\
\hline Walled In & 2009 & $\begin{array}{l}\text { Walled In - Mauern der Angst } \\
\text { Eingemauert (DVD) }\end{array}$ & Živi zazidani \\
\hline Wanderlust & 2012 & Wanderlust - Der Trip ihres Lebens & S njim i na kraj svijeta \\
\hline War of the World & 2005 & Krieg der Welten & Rat svjetova \\
\hline We Are Your Friends & 2015 & We Are Your Friends & We Are Your Friends \\
\hline We Need to Talk About Kevin & 2011 & We Need to Talk About Kevin & Moramo razgovarati o Kevinu \\
\hline We're the Millers & 2013 & Wir sind die Millers & Obitelj Miller \\
\hline Wet Hot American Summer & 2001 & Wet Hot American Summer & \\
\hline What a Girl Wants & 2003 & Was Mädchen wollen & Sve što djevojka može poželjeti \\
\hline What Happens in Vegas & 2008 & Love Vegas & Dok nas jackpot ne rastavi \\
\hline Whiplash & 2014 & Whiplash & Ritam ludila \\
\hline Wild & 2014 & Der große Trip - Wild & Divljina \\
\hline Wild Child & 2008 & Wild Child & Buntovnica u internatu \\
\hline Winter's Bone & 2010 & Winter's Bone & Zimska kost \\
\hline Woman in Gold & 2015 & Die Frau in Gold & Žena u zlatnom \\
\hline World War Z & 2013 & World War Z & Svjetski rat Z \\
\hline Would You Rather & 2012 & Tödliches Spiel - Would You Rather & \\
\hline Wreck-It Ralph & 2012 & Ralph reicht's & Krš i lom \\
\hline Wrong Turn & 2003 & Wrong Turn & Pogrešno skretanje \\
\hline Wrong Turn 2: Dead End & 2007 & Wrong Turn 2: Dead End & Pogrešno skretanje 2 \\
\hline
\end{tabular}




\begin{tabular}{|l|l|l|l|}
\hline Wrong Turn 3: Left for Dead & 2009 & Wrong Turn 3: Left for Dead & Pogrešno skretanje 3 \\
\hline Wrong Turn 4: Bloody Beginnings & 2011 & Wrong Turn 4: Bloody Beginnings & Pogrešno skretanje 4: Krvavi počeci \\
\hline Wrong Turn 5: Bloodlines & 2012 & Wrong Turn 5: Bloodlines & Pogrešno skretanje 5: Krvno srodstvo \\
\hline X2 & 2003 & X-Men 2 & X-Men 2 \\
\hline X-Men & 2000 & X-Men & X-Men \\
\hline X-Men Origins: Wolverine & 2009 & X-Men Origins: Wolverine & X-Men početak: Wolverine \\
\hline X-Men: Days of Future Past & 2014 & X-Men: Zukunft ist Vergangenheit & X-Men: Dani buduće prošlosti \\
\hline Yes Man & 2008 & Der Ja-Sager & Reci da \\
\hline You, Me and Dupree & 2006 & Ich, Du und der Andere & Svakog gosta tri dana dosta \\
\hline Young Adult & 2011 & Young Adult & Mlađa punoljetnica \\
\hline
\end{tabular}

